\title{
RODOLFO LUÍS KORTE
}

\section{FILARIOSE BANCROFTIANA NA AMAZÔNIA OCIDENTAL BRASILEIRA: IMPLICAÇÕES PARA TRANSMISSÃO E CONTROLE}

Tese apresentada ao Departamento de Parasitologia do Instituto de Ciências Biomédicas da Universidade de São Paulo, para obtenção do Título de Doutor em Ciências. 


\section{RODOLFO LUÍS KORTE}

\section{FILARIOSE BANCROFTIANA NA AMAZÔNIA OCIDENTAL BRASILEIRA: IMPLICAÇÕES PARA TRANSMISSÃO E CONTROLE}

Tese apresentada ao Departamento de Parasitologia do Instituto de Ciências Biomédicas da Universidade de São Paulo, para obtenção do Título de Doutor em Ciências.

Área de concentração: Biologia da Relação Patógeno-Hospedeiro

Orientador: Prof. Dr. Luís Marcelo Aranha Camargo

Versão corrigida. A versão original eletrônica encontra-se disponível tanto na Biblioteca do ICB quanto na Biblioteca Digital de Teses e Dissertações da USP (BDTB). 
DADOS DE CATALOGAÇÃO NA PUBLICAÇÃO (CIP)

Serviço de Biblioteca e Informação Biomédica do

Instituto de Ciências Biomédicas da Universidade de São Paulo

(c) reprodução total

Korte, Rodolfo Luis.

Filariose bancroftiana na Amazônia Ocidental brasileira: implicações para transmissão e controle / Rodolfo Luis Korte. -- São Paulo, 2013.

Orientador: Prof. Dr. Luís Marcelo Aranha Camargo.

Tese (Doutorado) - Universidade de São Paulo. Instituto de Ciências Biomédicas. Departamento de Parasitologia. Área de concentração: Biologia da Relação Patógeno-Hospedeiro. Linha de pesquisa: Medicina tropical.

Versão do título para o inglês: Survey of bancroftian filariasis infection in humans and culex mosquitoes in the Western Brazilian region: implications for transmission and control.

$\begin{array}{lll}\text { 1. Filariose linfática } & \text { 2. Filariose bancroftiana } & 3 \text {. Amazônia Ocidental }\end{array}$ 4. Wuchereria bancrofti 5. Culex quinquefasciatus 6. Epidemiologia I. Camargo, Prof. Dr. Luís Marcelo Aranha II. Universidade de São Paulo. Instituto de Ciências Biomédicas. Programa de Pós-Graduação em Biologia da Relação Patógeno-Hospedeiro III. Título. 
Candidato(a): $\quad$ Rodolfo Luis Korte.

Título da Tese: $\quad$ Filariose bancroftiana na Amazônia Ocidental brasileira: implicações para transmissão e controle.

Orientador(a): $\quad$ Prof. Dr. Luís Marcelo Aranha Camargo.

A Comissão Julgadora dos trabalhos de Defesa da Tese de Doutorado, em sessão pública realizada a .......................... considerou

( ) Aprovado(a)

( ) Reprovado(a)

\begin{tabular}{|c|c|}
\hline Examinador(a): & $\begin{array}{l}\text { Assinatura: } \\
\text { Nome: ......... } \\
\text { Instituição: . }\end{array}$ \\
\hline Examinador(a): & $\begin{array}{l}\text { Assinatura: } \\
\text { Nome: ......... } \\
\text { Instituição: . }\end{array}$ \\
\hline Examinador(a): & $\begin{array}{l}\text { Assinatura: } \\
\text { Nome: ......... } \\
\text { Instituição: . }\end{array}$ \\
\hline Examinador(a): & $\begin{array}{l}\text { Assinatura: } \\
\text { Nome: ......... } \\
\text { Instituição: . }\end{array}$ \\
\hline Presidente: & $\begin{array}{l}\text { Assinatura: } \\
\text { Nome: ......... } \\
\text { Instituição: . }\end{array}$ \\
\hline
\end{tabular}


Decl. CEPSH. $008 / 13$.

\section{E C L A R A Ç ̃̃ O}

Em adendo ao PARECER 937/CEP, de 27 de abril de 2010, declaro que esta Comissão não faz restrições às alterações propostas para o Projeto intitulado: "Estudo da ocorrência de filariose bancroftiana no municipio de Porto Velho, Rondônia" sob responsabilidade dos pesquisadores Prof. Dr. LuIs MARCELo ARANHA CAMARgo e Rodolfo Luis Korte, pois as mesmas não afetam os aspectos éticos da pesquisa.

São Paulo, 28 de fevereiro de 2013.

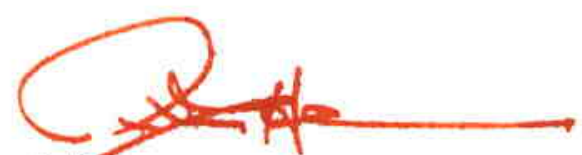

Prof Dr. Paolo M.A. Zanotto

Coordenador da Comissão de Ética em

Pesquisas com Seres Humanos - ICB /USP 
À Valéria, minha esposa

Uma vida sem a pessoa certa ao seu lado é muito mais difícil. Fui encontrado! O amor, companheirismo e dedicação tornaram possível esse sonho. Valéria é uma mulher que tem abraçado os meus sonhos, assim como eu os dela.

Aos meus filhos Julia, Sophia, Hugo e Felipe, que com seus questionamentos e companhia têm muito me ensinado e colaborado para o nosso crescimento.

Aos meus pais pelo apoio, dedicação e amor durante a toda a minha vida. 


\section{AGRADECIMENTOS ESPECIAIS}

Agradeço em especial ao amigo e Prof.Dr. Gilberto Fontes e Prof. Dra. Eliana Maria da Rocha pelas orientações, discussões e contrlbuições ao presente estudo.

Luís Marcelo amigo e orientador, que me ofereceu a oportunidade da realização deste estudo e com quem muito aprendi.

À Dilene Morais, aluna brilhante que com seu empenho e dedicação contribuiu e contagiou a todos os demais para a realização deste trabalho.

À FAPESP , pelo fomento para a realização do presente estudo. 


\section{AGRADECIMENTOS}

Agradeço aos alunos e colaboradores da Faculdade São Lucas e do ICB/USP Monte Negro pelo empenho durante todo o estudo, sem o qual este trabalho seria extremamente difícil.

Agradeço aos Amigos:

Sérgio Basano, Fábio Barbieri, Nilton Cavalcante, Luciana Gatto que me apoiaram nos momentos de angústia, dando-me força para levar adiante. 
“A Natureza é o médico das doenças. Ela própria encontra as vias e os meios, não através da inteligência, como os sinais, as palavras e outras ações desse gênero; a natureza, sem instrução e sem saber faz o que convém..... $O$ bom médico deve obdedecer à natureza... É agindo progressivamente que colocamos a natureza ao abrigo dos acidentes “

Hipócrates 
"É essa vontade de viver e de lutar pela vida que nos leva a conquistar os espaços físicos que nos cabem no mundo material. No mundo do abstrato a vontade de viver nos fazer lidar com ideias, linhas e formas de pensar"

Gustavo Korte 


\section{RESUMO}

KORTE, R. L. Filariose bancroftiana na amazônia ocidental brasileira: implicações para a transmissão e controle. 2013. 105 f. Tese (Doutorado em Biologia da Relação Patógeno-Hospedeiro) - Instituto de Ciências Biomédicas, Universidade de São Paulo, São Paulo, 2013.

Introdução: Este trabalho tem por objetivo identificar focos de filariose linfática na amazônia ocidental, partindo da premissa de que os últimos estudos são da década de 1950, realizados por Rachou e cols. Do mesmo modo, busca-se constatar a presença de Culex quinquefasciatus e sua infecção natural pela Wuchereria bancrofti. O estudo abrangeu as cidades de Porto Velho (RO), Guajará Mirim (RO) e Humaitá (AM). Método: Na concretização do trabalho foi utilizada a técnica da gota espessa de sangue, colhida após $22 \mathrm{~h} 00$, corada com Giemsa para avaliação humana, e a Reação em Cadeia da Polimerase (PCR) para pesquisa de DNA de $W$. bancrofti em mosquitos vetores. Foram analisadas e avaliadas amostras do sangue de moradores de todas as faixas etárias maiores do que 5 anos, dos bairros mais antigos dessas cidades, cuja principal característica é a ausência de saneamento básico e infraestrutura. Concomitantemente foram analisadas amostras de sangue de escolares frequentadores de cursos de ensino público noturnos nas mesmas áreas, além dos mosquitos capturados nas residências dos locais examinados. Resultados: Após avaliados por meio de inquéritos domiciliares, chegou-se aos seguintes números: 935 indivíduos $(54,4 \%)$ de um total de 1.720 cadastrados, sendo 641 em Porto Velho, 214 em Guajará-Mirim e 80 em Humaitá. As pesquisas entre escolares noturnos envolveram 2.709 indivíduos $(75,2 \%)$ de um total de 3.601 previamente selecionados, sendo: 1.684 em Porto Velho, 272 em Guajará-Mirim e 753 em Humaitá. Nas três localidades foram coletadas 7.849 fêmeas de Culex quinquefasciatus e, após avaliação de infecção natural utilizando a PCR, todas apresentaram resultados negativos para DNA de $W$. bancrofti. Igualmente, não foi encontrado microfilarêmico nas amostras populacionais. Conclusão: Através de diagnóstico hemoscópico de amostras de sangue da população humana pela gota espessa e avaliação de mosquitos vetores, concluiu-se que as áreas estudadas são indenes para $W$. bancrofti.

Palavras-chave: Filariose linfática. Filariose bancroftiana. Amazônia. Wuchereria bancrofti. Culex quinquefasciatus. Bancroftose. Epidemiologia. 


\begin{abstract}
KORTE, R. L. Survey of Bancroftian filariasis infection in humans and Culex mosquitoes in the western Brazilian Amazon region: implications for transmission and control. 2013. 105 p. Ph. D. Thesis (Biology of Host-Pathogen Interactions) Instituto de Ciências Biomédicas, Universidade de São Paulo, São Paulo, 2013.

Introduction: This work is aimed to identify possible lymphatic filariasis foci in the Western Brazilian Amazonian rainforest that could be established since the reports of Rachou and cols in 1950's, and as well find possible presence of Culex quinquefasciatus with natural infection by Wuchereria bancrofti. Porto Velho and Guajara-Mirim (Rondonia State) and Humaita (Amazonas State), all in the north region of Brazil, were the study target area. Methods: Blood thick film method with samples collected from 10 PM to 1 AM were stained using Giemsa to evaluate human infection and Polymerase Chain Reaction for $W$. bancrofti DNA in mosquitoes vectors. Samples from the neighborhoods of people over 5 years old of areas lacking sanitation systems and also samples from students attending public nighttime classes in the cities referred to above were analyzed and evaluated, as well as mosquitoes captured in the houses. Results: Nine hundred and thirty-five individuals $(54.4 \%)$ out of a total of 1,720 individuals engaged were evaluated based on the domicile probes. Sample with night students involving 2,709 individuals $(75.2 \%)$ out of the total of 3,601 previously selected. No individuals were positive for the presence of microfilariae in the blood stream. Seven thousand eight hundred and forty nine female Culex quinquefasciatus specimens were captured and after evaluated by using PCR method, all of them were found negative for Wuchereria bancrofti DNA. Conclusion: By carrying out haemoscopic examination of the human population samples and the mosquito vectors, the conclusion is that actually such target areas are not affected by W. bancrofti transmission.
\end{abstract}

Keywords: Lymphatic filariasis. Bancroftian filariasis. Western Brazilian Amazonia. Wuchereria bancrofti. Culex quinquefasciatus. Epidemiology. 


\section{LISTA DE ABREVIATURAS E SIGLAS}

\begin{tabular}{ll} 
An. & Anopheles \\
AL & Alagoas \\
Ag & Antígeno \\
AM & Amazonas \\
Alb & albendazol \\
Ac & anticorpo \\
AM & Amazonas \\
B. & Brugya \\
C. & Culex \\
CDC & Center of Disease Control and Prevention \\
DEC & Dietilcarbamazine \\
DEC-ALB & Dietilcarbamazine-albendazol \\
DEC-IVM & Dietilcarbamazine-Ivermectina \\
DLLA & Dermatolinfoangioadenite Aguda \\
DNA & Äcido desoxiribonucléico \\
EP & Poros excretores \\
EPT & Eosinofilia Pulmonar tropical \\
FET & Fibrose Endomiocárica Tropical \\
GE & Gota espessa \\
g/L & gramas por litro \\
g/kg & gramas por kilo \\
ICB/USP & Instituto de Ciências Biomédicas da Universidade de São \\
& Paulo \\
ICT & Imunocromatografic Test \\
IgE & Imunoglobulina E \\
lgG & Imunoglobulina G \\
lgM & Imunoglobulina M \\
km & Kilômetro \\
LAF & Linfangíte Aguda filarial \\
L.loa & Loa loa \\
L1 & Larva 1 \\
L2 & Larva 2 \\
L3 & Larva 3 \\
M. & Mansonia \\
$\mathrm{m}$ & metro \\
$\mathrm{min}$ & minuto \\
$\mathrm{mm}$ & Milímetro \\
$\mathrm{mf} / \mathrm{mL}$ & Microfilárias por mililitro \\
$\mathrm{ml}$ & mililitro \\
$\mathrm{mg} /$ dia & miligrama por dia \\
$\mathrm{MS}$ & Ministério da Saúde \\
$\mathrm{MSD}$ & Membro superior direito \\
$\mathrm{OMS}$ & Organização Mundial da Saúde \\
$\mathrm{PA}$ & Pará \\
$\mu$ & micra \\
$\mu \mathrm{LL}$ & microlitro \\
$\mu \mathrm{m}$ & micrômetro \\
$\mathrm{NC}$ & Núcleos da cauda \\
& \\
\hline
\end{tabular}




$\begin{array}{ll}\text { NR } & \text { Anel neural } \\ \text { PCR } & \text { Reação em Cadeia da Polimerase } \\ \text { RO } & \text { Rondônia } \\ \text { AIDS } & \text { Síndrome da Imunodeficiência Adquirida } \\ \text { Sh } & \text { Sheath (bainha) } \\ \text { UFAL } & \text { Universidade Federal de Alagoas } \\ \text { USG } & \text { Ultrassom } \\ \text { VEGF-A } & \text { Vascular Endotelial Growth Factor -A } \\ \text { VEGT-C } & \text { Vascular Endotelial Growth factor -C } \\ \text { VEGFR } & \text { Vascular Endotelial Growth factor Receptor }\end{array}$




\section{LISTA DE ILUSTRAÇÕES}

Quadro 1 - Filarioses humanas ao redor do mundo, sistema acometido, localização das microfilárias e quadro clínico 22

Figura 1 - Formas adultas de $W$.bancrofti macho e fêmea .23

Figura 2 - Microfilária de $W$.bancrofti em esfregaço de sangue, corada com Giemsa

Figura 3 - Papila caudal de forma larval L3 25

Quadro 2 - Tabela da periodicidade das microfilaremias em relação à geografia e parasita.

Figura 4 - Momento da saída do parasito na forma larval L3 para infectar o ser humano.

Figura 5 - Larva infectante $\left(L_{3}\right)$ de $W$. bancrofti junto à probóscide de fêmea de Culex quinquefasciatus 27

Figura 6 - Ciclo de vida da $W$. bancrofti 28

Figura 7 - Mosquito C. quinquefasciatus, também conhecido como carapanã, pernilongo ou muriçoca. 30

Figura 8 - Forma crônica de filariose com linfedema de Membro inferior esquerdo 32

Figura 9 - Paciente portador de filariose linfática crônica com hidrocele 34

Figura 10 - RX de pneumonia eosinofílica crônica idiopática 35

Figura 11.a - Preparo do dedo para punção pela técnica da gota espessa....37

Figura 11.b - gota espessa a ser coletada .38

Figura 12 - Diferenciação das espécies de microfilárias com base na presença ou ausência do núcleo da cauda (NC) e da bainha (SH-sheath).............................38

Figura 13 - Foto da área de pesquisa em Porto Velho, RO............................49

Figura 14 - Casa padrão em Guajará-Mirim, RO .......................................50

Figura 15 - Foto das casas do bairro Comunidade Santo Antonio, Humaitá, AM. .50

Figura 16 - Foto de casas do bairro Triângulo, da área de pesquisa em Porto Velho.

Figura 17 - Área de estudo de Porto Velho dos três bairros, Triângulo, Candelária e Baixa União, contornados por linha branca,2008. 52

Figura 18 - Parte 1, em amarelo, áreas de menor risco, em vermelho, áreas de risco. Porto Velho, 2008. 
Figura 19 - Parte 2, em amarelo, áreas de menor risco, e em vermelho, áreas de risco, Porto Velho, 2008.

Figura 20 - Parte 3, em amarelo, áreas de menor risco, e em vermelho, áreas de risco, Porto Velho, 2008.

Figura 21 - Parte 4, em amarelo, áreas de menor risco, em Porto Velho, 2008

Figura 22 - Parte 5, em amarelo, áreas de menor risco, e em vermelho, áreas de risco, Porto Velho, 2008.

Figura 23 - Parte 6, em amarelo, áreas de menor risco, em Porto Velho, 2008

Figura 24 - Parte 7, em amarelo, áreas de menor risco, em Porto Velho, 2008

Figura 25 - Foto com cadastro na casa a ser visitada no período noturno (com guias de coleta entomológica e para visitação). 57

Figura 26 - Foto do bairro Triângulo em Guajará-Mirim, Rondônia, 2008. .58

Figura 27- Gota espessa de sangue (A), desemoglobinizada e fixada com metanol (B), e corada (C) para exame ao microscópio óptico. .60 Figura 28 - Mapa da cidade de Porto Velho das áreas de pesquisa em escolares noturnos. .63

Figuras 29.a Palestra dos colaboradores na Escola Estadual Carmela Dutra, maio de 2009

29.b - Palestra dos colaboradores na Escola Estadual Gov. Osvaldo Piana, maio de 2009 .65

Figura 30 - Delimitação da área de estudo dos escolares noturnos, em GuajaráMirim, 2009 66

Figura 31 - Detecção de DNA de W.bancrofti pela PCR .68 
1 INTRODUÇÃO

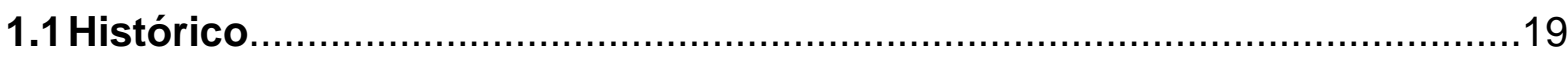

1.1.1 Filarioses ao redor do Mundo

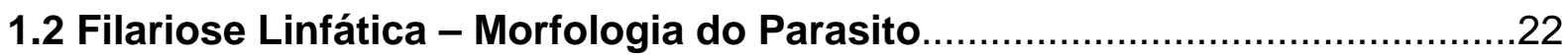

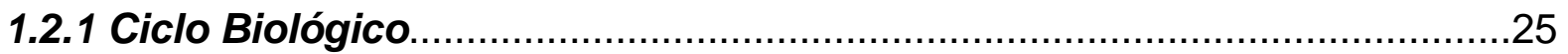

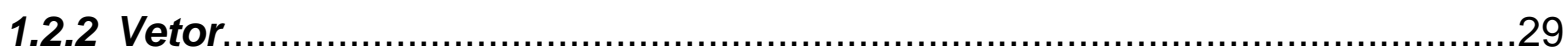

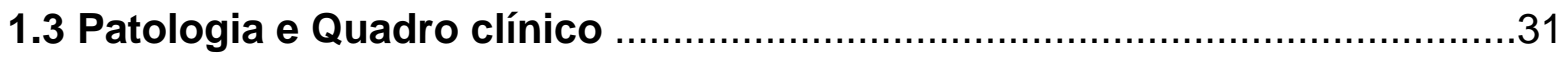

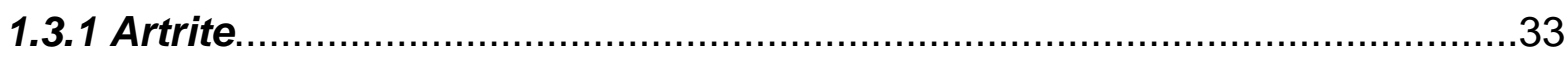

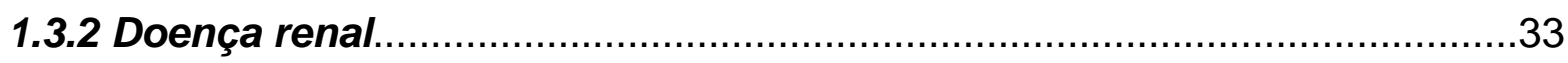

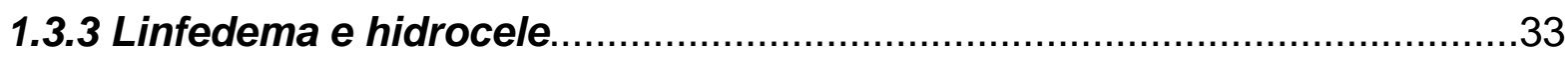

1.3.4 Quilúria

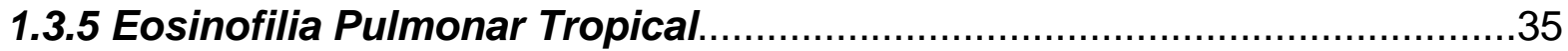

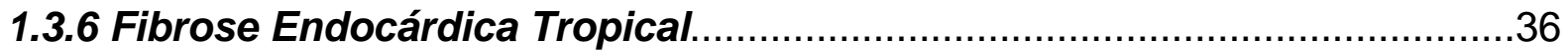

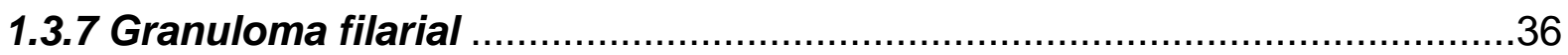

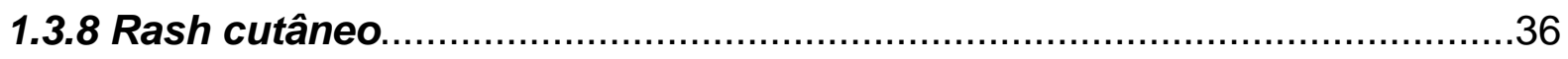

1.4 Diagnóstico

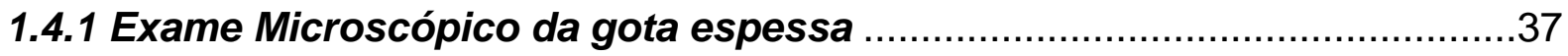

1.4.2 Filtração com membrana de policarbonato..............................................39

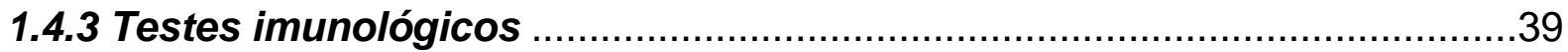

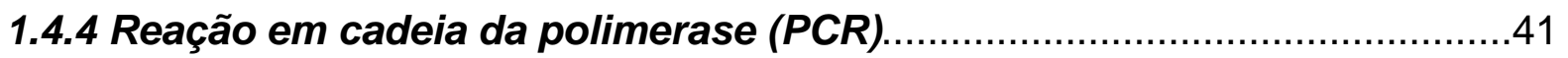

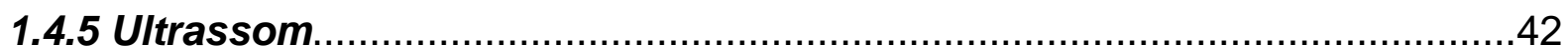

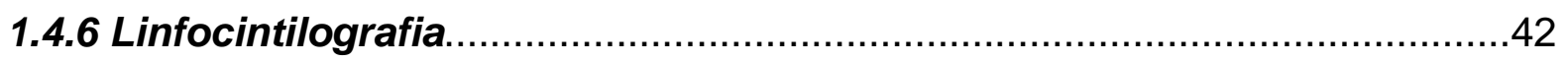

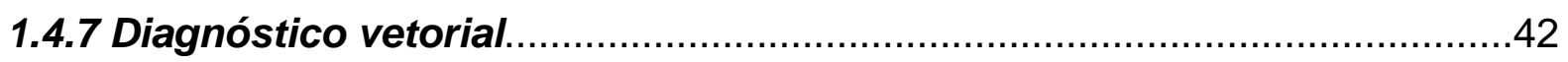

1.5 Tratamento

1.5.1 DEC, IVM, ALB

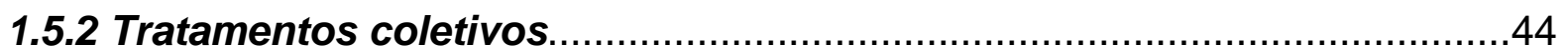

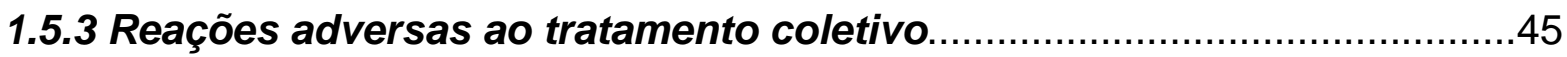

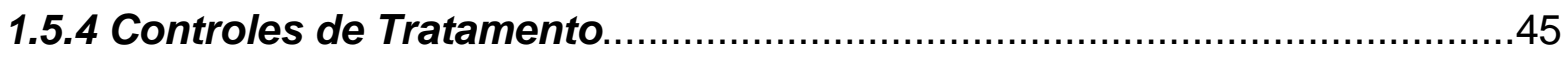

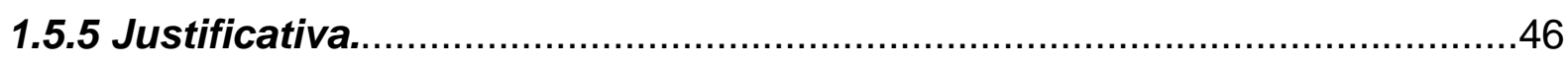

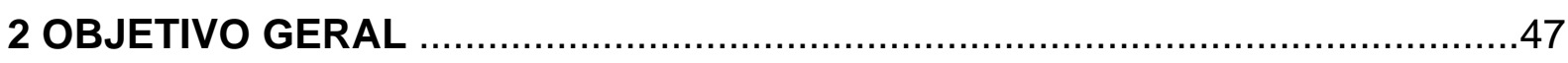

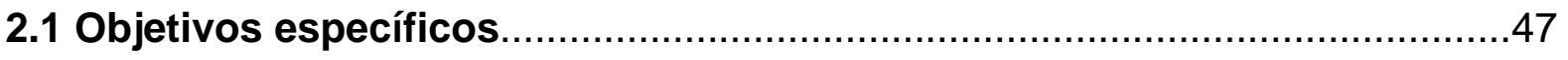

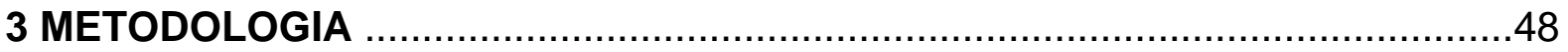




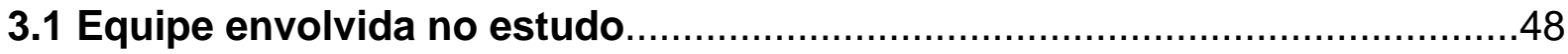

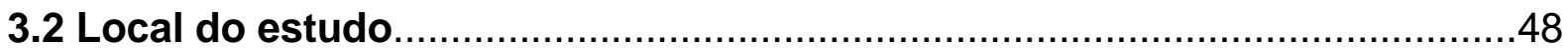

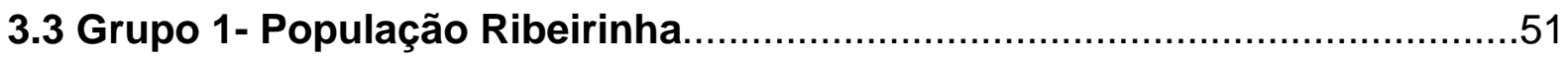

3.3.1 Grupo 2 - Escolares Noturnos de escolas públicas...............................56

3.3.2 Determinação da Prevalência Humana de Microfilarêmicos em Visita às

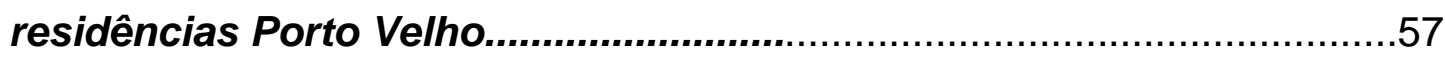

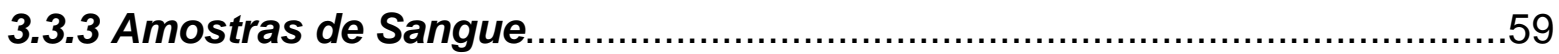

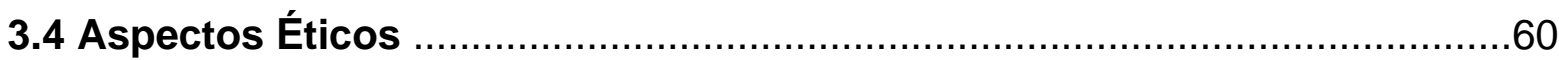

3.5 Pesquisa com vetores em Porto Velho, Guajará-Mirim e Humaitá..............61

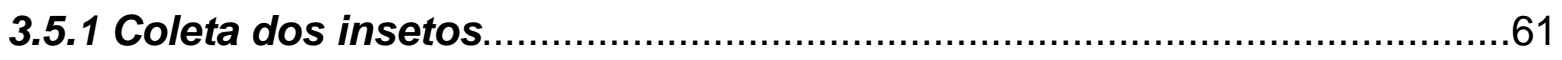

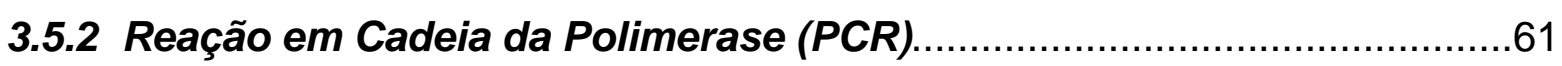

3.6 Grupo 2 - Alunos do Período Noturno das Escolas Públicas de Porto

Velho.

3.6.1 Alunos do Período Noturno das Escolas Públicas de Guajará-Mirim e

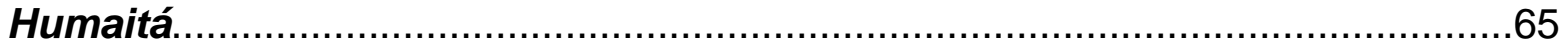

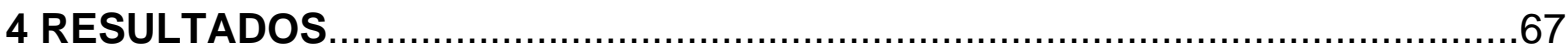

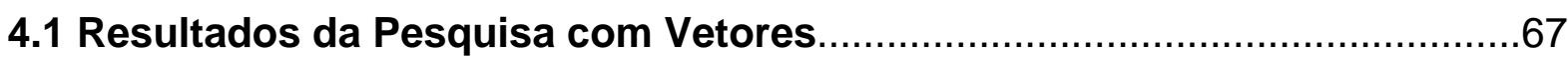

4.2 Resultados da Pesquisa em Seres Humanos..........................................69

4.2.1 Inquéritos domiciliares em Porto Velho, Guajará-Mirim e Humaitá...........69

4.2.2 Resultados da Pesquisa com escolares noturnos .................................70

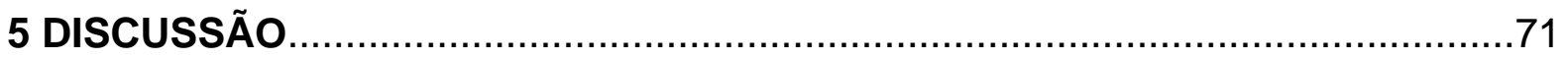

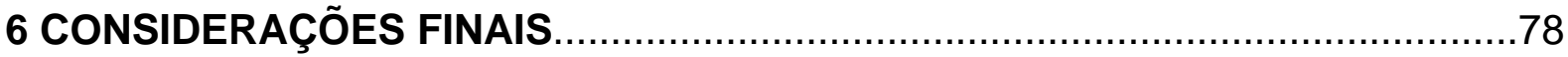

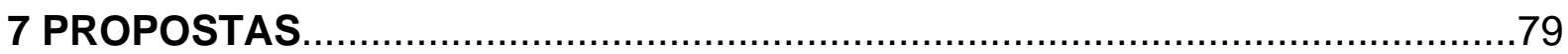

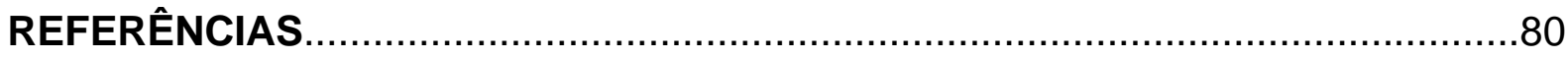

APÊNDICE A - Ficha de coleta entomológica ...............................................

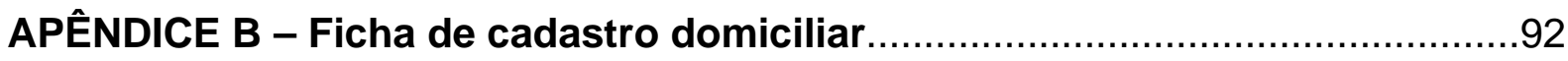

APÊNDICE C - Termo de consentimento dos moradores..................................93

APÊNDICE D - Termo de consentimento escolares............................................94

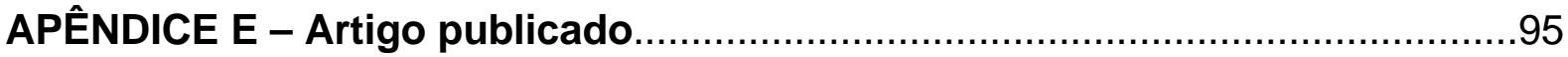

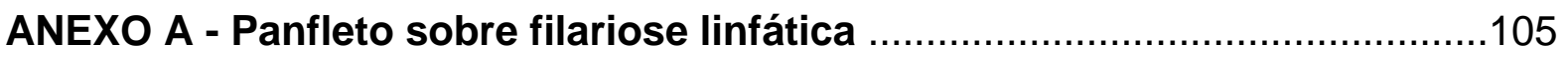

ANEXO B - Resolução 50.29 da WHA - World Health Assembly....................106 


\section{Introdução}

A filariose linfática é uma doença parasitária, exclusivamente humana, provocada por helmintos nematóides (Spirurida: Onchocercidae) das espécies Wuchereria bancrofti (Cobbold, 1877), Brugia malayi (Bucley \& Edeson, 1956) e Brugia timori (Partono, 1977).

Faz parte de um grupo de 17 enfermidades que representam as doenças mais frequentes e comuns das populações pobres ao redor do mundo. É uma doença que ocorre em áreas carentes de saneamento básico, principalmente onde há escassez de água potável, esgoto a céu aberto, e a população, via de regra, possui baixa escolaridade e sistema de saúde precário (FREITAS et al., 2008).

Por ser negligenciada (ADDIS; BRADY, 2007), acometendo principalmente crianças, mulheres grávidas e indivíduos jovens em idade economicamente produtiva, acaba contribuindo negativamente para o desenvolvimento econômico dos países onde ocorre (HOTEZ; SAVIOLI; FENWICK, 2012).

Entretanto, nos termos da Resolução n. 50.29/1997 da ONU/ Organização Mundial de Saúde foi estabelecida uma meta para sua eliminação, tomando-se como data limite o ano de 2020 (ANEXO B).

Atualmente, mais de 1,3 bilhão de pessoas estão em risco de desenvolver a doença, distribuída entre 72 países, sendo que aproximadamente 65\% dessas pessoas vivem no sudoeste asiático, $30 \%$ na África e o restante em áreas de clima tropical e subtropical ao redor do mundo (FONTES et al., 2012; WHO, 2008).

Nas Américas, os focos ativos concentram-se principalmente no Brasil, Guiana, República Dominicana e Haiti, com cerca de 12,4 milhões de pessoas necessitando de tratamento. O Haiti é o país que apresenta a maior prevalência da doença (WHO, 2011).

Dentre as espécies causadoras da filariose linfática, no Brasil encontra-se exclusivamente o parasito da espécie W. bancrofti, não obstante haver outros filarídeos como Onchocerca volvulus (UDALL et al., 2007), Mansonella ozzardi e Mansonella perstans na Amazônia (TANG et al., 2010), que parasitam humanos causando variadas formas clínicas de doença (BASANO et al., 2011).

W. bancrofti tem o ser humano como o seu único reservatório, e no Brasil é veiculado por vetores biológicos, tais como culicídeos (transmissores do causador 
da filariose bancroftiana), simulídeos e ceratopogonídeos (transmissores da oncocercose e mansonelose).

Enquanto a oncocercose e a mansonelose são mais frequentes nas áreas ribeirinhas, a filariose bancroftiana ocorre em áreas urbanas (BASANO et al., 2011).

Atualmente, o único foco da filariose bancroftiana conhecido no Brasil encontra-se na região metropolitana de Recife, que engloba as cidades de Recife, Olinda, Jaboatão dos Guararapes e Paulista (Pernambuco) (FONTES et al., 2012). As cidades de Belém (Pará) e Manaus (Amazonas), localizadas na região amazônica, e a cidade de Maceió (Alagoas), localizada na região nordeste do Brasil, foram descritas como focos endêmicos no passado e nestas localidades os focos estão extintos e a população permanece constantemente em observação (FONTES et al., 2012).

Sob esse prisma, o foco do presente estudo será a abordagem da filariose bancroftiana na região amazônica, englobando as cidades de Porto Velho (RO), Guajará-Mirim (RO) e Humaitá (AM), a partir dos últimos estudos realizados por Rachou et al., que remontam à década de 1950 (RACHOU, 1957).

\subsection{Histórico}

Casos de filariose são descritos desde a Grécia e Roma antigas, seja em documentos, seja em estatuetas. A estátua do faraó Mentuhotep, de cerca de 2000 a.C., mostra o inchaço característico das pernas. E a hidrocele é retratada em esculturas africanas Nok, de cerca de 500 dC Em 1877, Joseph Bancroft descobriu um verme ao examinar o fluido de um paciente com um abcesso no braço, uma complicação rara da doença. Enviou este material para o mais influente helmintologista médico, Stephen Cobbold, que o descreveu e chamou de Filaria bancrofti em uma nota para a revista Lancet.

A filariose bancroftiana foi introduzida no continente americano, inclusive no Brasil, através do tráfico de escravos africanos durante o período colonial (ORIHEL, 1985). Aqui se disseminou após ter encontrado um vetor compatível: o mosquito Culex quinquefasciatus (Figura 8).

Durante a década de 1950, entre os anos de 1950 a 1958, foi realizado um inquérito hemoscópico pelo médico e sanitarista René Rachou em 24 estados brasileiros, alcançando 852 localidades, num total de 811.361 indivíduos e, 
paralelamente, foi realizado um inquérito entomológico por meio da dissecação de 120.399 exemplares de diferentes espécies de mosquitos, em 12 dos estados pesquisados (FRANCO; SILVA-LIMA, 1967). Como resultado geral, Rachou detectou a presença de portadores de $W$. bancrofti em 89 localidades de 8 estados brasileiros e, devido ao encontro em paralelo de vetores com larvas infectantes do parasito, observou a transmissão ativa da filariose linfática apenas em 11 localidades (RACHOU, 1960).

A partir dos resultados encontrados, foi providenciado na época, nas áreas com transmissão ativa, o tratamento específico dos indivíduos microfilarêmicos, o que contribuiu para a redução significativa dos índices da doença, à época. Todavia não foram realizados acompanhamentos de indivíduos tratados nas áreas onde não foi constatada a transmissão ativa da doença (casos alóctones).

Em Porto Velho, na década de 1950, foram examinados 1.400 indivíduos (12\% da população), constatando $6(0,4 \%)$ positivos para microfilárias de $W$. bancrofti (RACHOU; LACERDA; COSTA, 1954). No entanto, nenhum destes casos foi considerado autóctone, pois foram encontrados em migrantes de áreas conhecidas como endêmicas, como Belém (PA) e Manaus (AM), e que viviam em Porto Velho por um período menor que o período pré-patente do parasito.

No ano de 1951, em Maceió (AL), foram examinados 6.052 indivíduos (6\% da população), encontrando $18(0,3 \%)$ microfilarêmicos, todos considerados como autóctones (DEANE et al., 1953).

Em 1953, realizou um exame hemoscópico na cidade de Guajará-Mirim (RO), abrangendo 603 indivíduos, mas apenas 1 caso $(0,2 \%)$ apresentou microfilária de $W$. bancrofti. Em Humaitá (AM) o inquérito envolveu 435 indivíduos, mas nenhum foi positivo para a doença (RACHOU, 1957).

Assim, no ano de 1985, o Ministério da Saúde (MS) considerou que a transmissão de $W$. bancrofti encontrava-se presente apenas nas cidades de Belém e Recife, tendo sido eliminada nas demais cidades da pesquisa realizada por Rachou na década de 1960. Porém, muito embora o Ministério da Saúde mantivesse tal posicionamento, a realidade indicava outro rumo. Com o trabalho desenvolvido por Dreyer e colaboradores em 1991, em exame de militares do exército na cidade de Maceíó ( $A L)$, constatou-se a presença de dois casos autóctones da enfermidade naquela cidade (DREYER et al., 1991).

Em seguida, Fontes e colaboradores estudando escolares noturnos dos 33 
bairros existentes em Maceió ( $A L)$, mostraram a existência de indivíduos parasitados por W. bancrofti e que a sua distribuição estava restrita a uma área central da cidade, formada por parte de três bairros contíguos: Feitosa, Jacintinho e Pitanguinha (FONTES et al., 1998). Essas localidades apresentavam as características ideais para o desenvolvimento do mosquito vetor e disseminação do parasito, ou seja, esgoto a céu aberto, infraestrutura precária e ausência de água tratada (MATTOS; DREYER, 2008).

Ambos os estudos contrariavam as informações do Ministério da Saúde (BRASIL, 1985), que indicava não haver nem a doença, nem a transmissão de filariose linfática na cidade de Maceió. No final, o Ministério da Saúde confirmou que houve uma falha na avaliação diagnóstica, uma vez que a doença se instalou e se disseminou, mesmo com as medidas tomadas na década de 1960.

Com isso, concluiu-se que o mesmo fato poderia estar ocorrendo nas cidades de Porto Velho, Guajará-Mirim e Humaitá, pois desde a descoberta de casos de microfilarêmicos por $W$. bancrofti na década de 1950, nenhum outro estudo sobre a epidemiologia da filariose linfática foi realizado nestas regiões.

\subsubsection{Filarioses ao Redor do Mundo}

São nove os principais vermes filariais que parasitam o ser humano: $W$. bancrofti, Brugia malayi, B. timori, Onchocerca volvulus, Loa loa, Mansonella streptocerca, M. ozzardi, M. perstans e Dracunculus medinensis (Quadro 1).

As filárias W. bancrofti, B. malayi, e B. timori são as causadoras da filariose linfática e a $O$. volvulus é a causadora da oncocercose ou cegueira dos rios. São parasitos de grande interesse médico por afetarem milhões de pessoas ao redor do mundo, e pouco estudados dada a inexistência de um modelo ideal experimental, uma vez que o ser humano é o único hospedeiro definitivo (MICHALSKI et al., 2011).

A filariose linfática causada pela $W$. bancrofti corresponde a aproximadamente $90 \%$ dos casos de filariose linfática no mundo. Os demais casos são causados principalmente pela B.malayi e também pela B.timori. (FONTES et al., 2012). 
Quadro 1 - Filarioses humanas ao redor do mundo, sistema acometido, localização das microfilárias e quadro clínico.

\begin{tabular}{|c|c|c|c|c|c|}
\hline Parasito & Ocorrência & $\begin{array}{l}\text { Localização } \\
\text { dos vermes } \\
\text { adultos }\end{array}$ & Microfilárias & $\begin{array}{l}\text { Vetores da } \\
\text { trnsmissão }\end{array}$ & Patologias \\
\hline W. bancrofti & $\begin{array}{l}\text { Africa, Asia } \\
\text { Américas }\end{array}$ & Linfática & sangue & $\begin{array}{c}\text { Cx. } \\
\text { quinquefasciatus, } \\
\text { Anopheles spp., } \\
\text { Aedes spp. }\end{array}$ & $\begin{array}{l}\text { Linfangite } \\
\text { Elefantíase }\end{array}$ \\
\hline Brugia malayi & Asia & Linfática & sangue & Mansonia spp. & Linfangite \\
\hline Brugia timori & Indonésia & Linfática & sangue & An. barbirostris & Linfangite \\
\hline $\begin{array}{c}\text { Onchocerca } \\
\text { volvulus }\end{array}$ & $\begin{array}{c}\text { Africa, Central } \\
\& \\
\text { América do } \\
\text { Sul, } \\
\text { Yemen }\end{array}$ & $\begin{array}{l}\text { Pele, nódulos } \\
\text { subcutâneos e } \\
\text { olhos }\end{array}$ & pele & Simulium sp. & $\begin{array}{c}\text { Dermatites, } \\
\text { lesões } \\
\text { oculares, } \\
\text { cegueira }\end{array}$ \\
\hline Loa loa & África & $\begin{array}{c}\text { Tecidos } \\
\text { subcutâneos }\end{array}$ & sangue & Tabanídeos & $\begin{array}{c}\text { Edema } \\
\text { Calabar, } \\
\text { irritação nos } \\
\text { olhos } \\
\text { febre }\end{array}$ \\
\hline $\begin{array}{c}\text { Mansonella } \\
\text { ozzardi }\end{array}$ & $\begin{array}{c}\text { América } \\
\text { Central e Sul }\end{array}$ & $\begin{array}{l}\text { Mesentério e } \\
\text { Parede } \\
\text { Abdominal }\end{array}$ & $\begin{array}{l}\text { Sangue e } \\
\text { pele }\end{array}$ & Simulium sp & $\begin{array}{l}\text { Edema } \\
\text { linfóide, dor } \\
\text { articular } \\
\text { febre }\end{array}$ \\
\hline $\begin{array}{c}\text { Mansonella } \\
\text { perstans }\end{array}$ & $\begin{array}{c}\text { América } \\
\text { Central e Sul }\end{array}$ & $\begin{array}{c}\text { Tecido } \\
\text { perirenal, } \\
\text { cavidade peural } \\
\text { e pericárdio }\end{array}$ & sangue & Culicideos & $\begin{array}{l}\text { Dor articular } \\
\text { febre }\end{array}$ \\
\hline $\begin{array}{l}\text { Mansonella } \\
\text { streptocerca }\end{array}$ & $\begin{array}{c}\text { África e } \\
\text { Américas }\end{array}$ & $\begin{array}{c}\text { Tecido } \\
\text { subcutâneo }\end{array}$ & $\begin{array}{l}\text { Pele e } \\
\text { sangue }\end{array}$ & Culicideos & $\begin{array}{l}\text { Prurido, dor } \\
\text { articular. febre }\end{array}$ \\
\hline $\begin{array}{l}\text { Dracunculus } \\
\text { medinensis }\end{array}$ & $\begin{array}{c}\text { Américas Asia } \\
\text { e Africa }\end{array}$ & $\begin{array}{c}\text { Tecido } \\
\text { subcutâneo }\end{array}$ & pele & $\begin{array}{l}\text { Microcrustaceans } \\
\text { (Cyclops) }\end{array}$ & $\begin{array}{c}\text { Ulcerações na } \\
\text { pele, bolhas }\end{array}$ \\
\hline
\end{tabular}

Fonte: Nanduri e Kazura, 1989; Payli, Hoti e Das, 2009 modificada.

\subsection{Filariose Linfática - Morfologia do Parasito}

\section{Parasito: Wuchereria bancrofti}

Adultos: Possuem corpo longo e delgado, branco leitoso, opacos, com cutícula lisa e sexos distintos (Figura 1).

Macho: mede de 3,5 a $4 \mathrm{~cm}$ de comprimento e $0,1 \mathrm{~mm}$ de diâmetro, com a extremidade anterior afilada e posterior enrolada ventralmente.

Fêmea: mede de 7 a $10 \mathrm{~cm}$ de comprimento e $0,3 \mathrm{~mm}$ de diâmetro, possui orgãos genitais duplos, com exceção da vagina, que é única e se exterioriza em uma vulva localizada próximo à extremidade anterior do parasito. A reprodução é sexuada, possui dois tubos uterinos que ocupam grande parte do corpo. Os ovos 
são observados na porção mais posterior, enquanto que os embriões e as microfilárias imaturas ficam mais próximas da vagina (FONTES e Rocha, 2005).

Figura 1 - Formas adultas de $W$. bancrofti - macho à direita e fêmea à esquerda

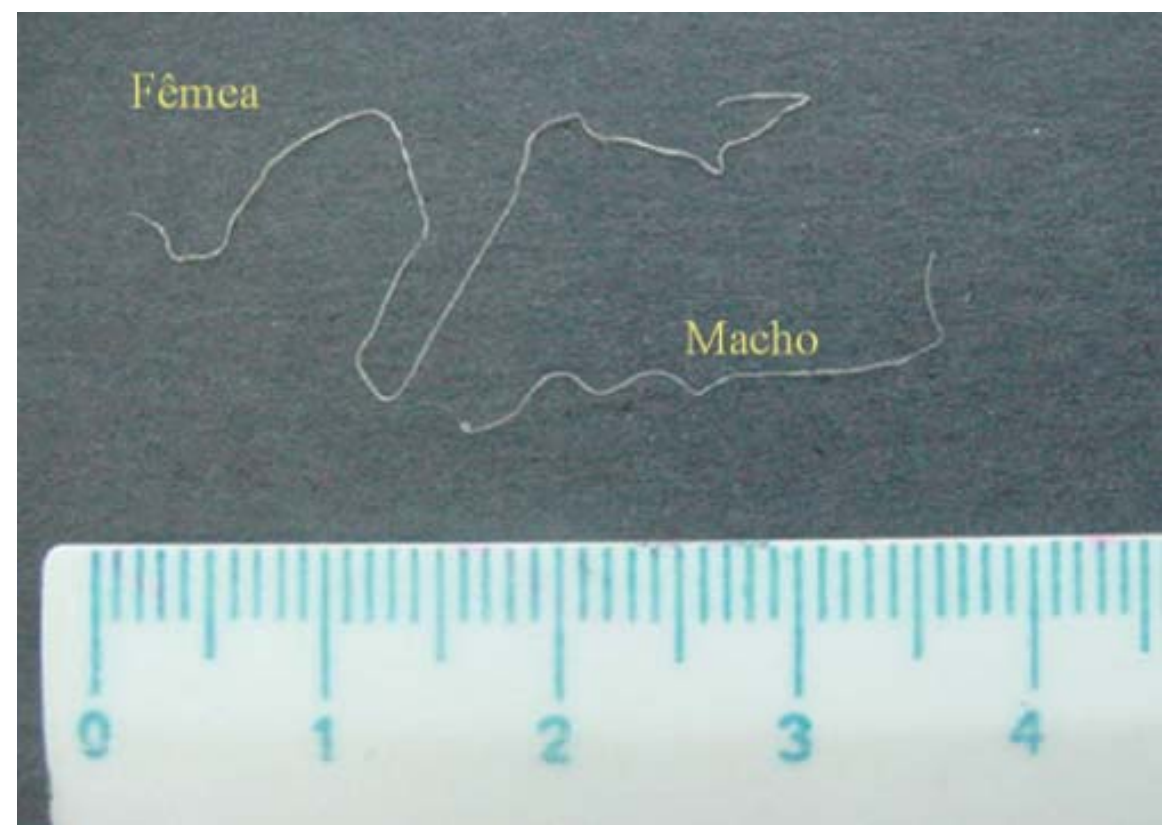

Fonte: Brasil, 2009

Microfilárias (Figura 2): são conhecidas também como embriões. Saem das fêmeas grávidas nos vasos linfáticos, ganham a circulação, movimentando-se ativamente. Medem de 250 a $300 \mu \mathrm{m}$ de comprimento e possuem uma membrana de revestimento (bainha) que é flexível. A identificação desta bainha é um dos critérios morfológicos para a diferenciação de outros filarídeos (Figura 2). Podem ser observadas vivas e em movimento ativo em lâminas com sangue, logo após ser colhido do indivíduo parasitado.

Formas larvais: são três as formas larvais encontradas no vetor. A primeira é a L1, tem forma "salsichoide" e mede em torno de $300 \mu \mathrm{m}$. As larvas L2 têm tamanho aproximado de $700 \mu \mathrm{m}$ de comprimento e na última fase de desenvolvimento as larvas infectantes, denominadas de larvas L3 (Figura 3), possuem comprimento entre 1,5 e 2,0 mm (FONTES; ROCHA, 2005).

Após a entrada da microfilária no vetor, em poucas horas, perdem a sua bainha de revestimento, atravessam a parede do estômago, alojam-se nos músculos torácicos e transformam-se em L1. Seis a 10 dias após, ocorre a segunda muda transformando-se em L2. Esta cresce muito, e entre 10 e 15 dias sofre a terceira 
muda, a forma infectante $\mathrm{L} 3$, que migra para a probóscide do inseto. $\mathrm{O}$ tempo de transformação de L2 para L3 pode variar em função da umidade e temperatura ambiente, e pode chegar até 6 semanas (CHANDRA, 2008).

Morfologicamente apresentam uma grande quantidade de núcleos na região caudal (células germinativas caudais), dispostos em filas simples. As células somáticas constituem o tubo digestivo e outros órgãos, participando também da formação do aparelho genital. Alguns espaços sem núcleos correspondem a outras estruturas em formação, como anel nervoso, poro e célula excretora (PAILY; HOTI; DAS, 2009).

Figura 2 - Microfilária de $W$. bancrofti em gota espessa de sangue corada pelo método de Giemsa (400X). Observar a bainha de revestimento característica (seta).

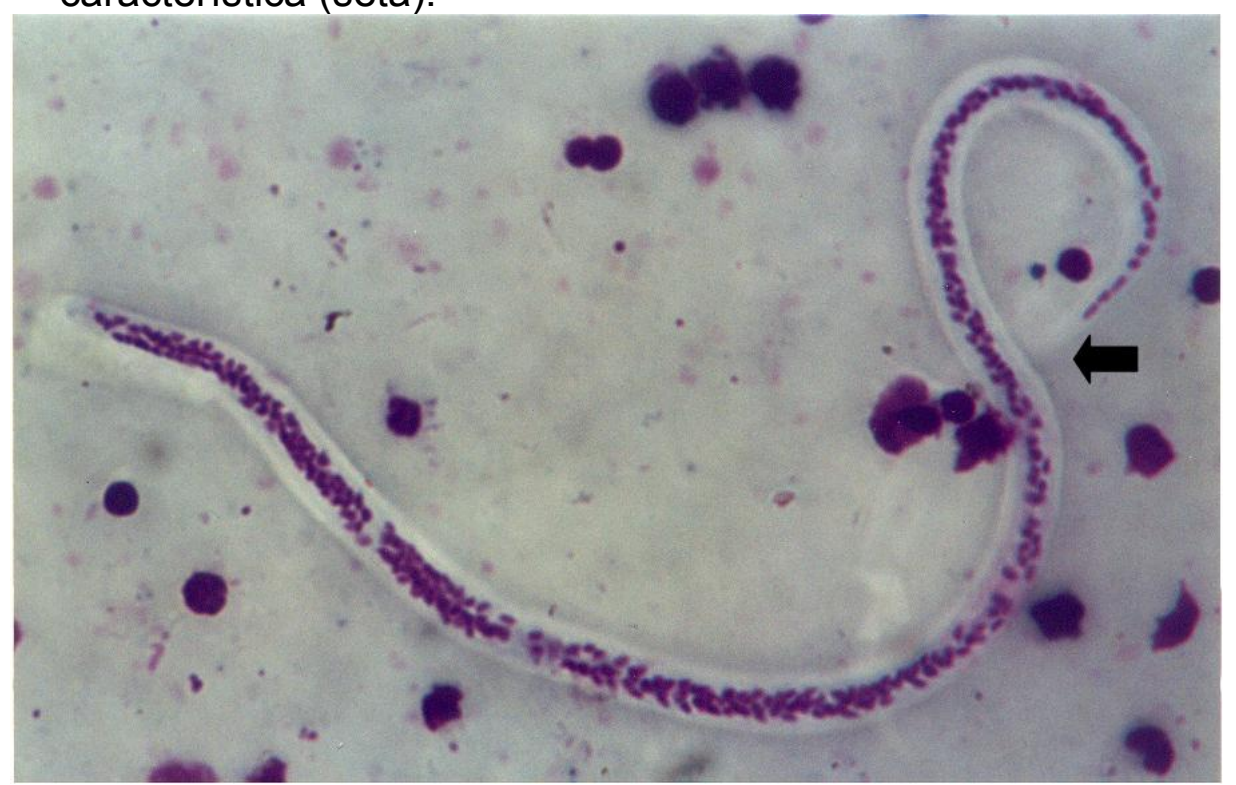

Fonte: Fontes e Rocha, 2004 
Figura 3 - Papila caudal de forma larval L3 de W. bancrofti (400X)

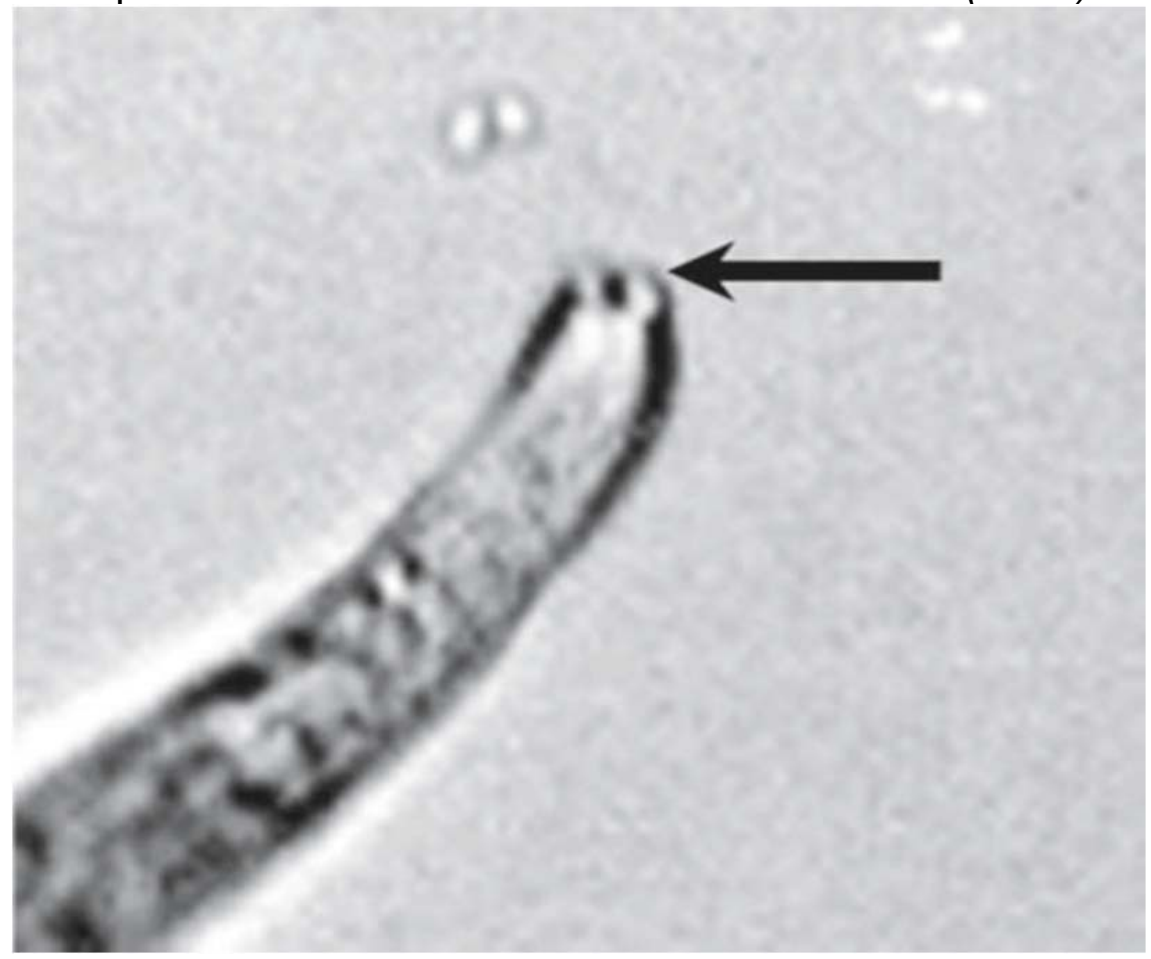

Fonte: Paily, Hoti e Das, 2009.

\subsubsection{Ciclo biológico}

W. bancrofti, por ser um parasito heteroxênico, necessita de um estágio de maturação empregando artrópodes como hospedeiros intermediários e outro no hospedeiro definitivo, o homem, para completar seu ciclo evolutivo (Figura 5).

O ciclo intrínseco ocorre a partir da penetração da larva infectante (L3) após ter sido depositada pelo mosquito sobre a pele do indivíduo, no ato da hemofagia.

A larva migra através da circulação sanguínea e se instala nos vasos linfáticos ou linfonodos, onde realiza duas mudanças até atingir a fase adulta. Aproximadamente entre 9 e 10 dias pós a entrada, a forma larval L3, sofre a primeira mudança para L4.

$\mathrm{Na}$ forma larval L4 sofre um processo de desenvolvimento que pode durar dias ou meses, para somente após chegar na forma evolutiva final: a forma adulta.

Estudos demonstram que a longevidade de uma fêmea de W.bancrofti é de até 10,2 anos, produzindo microfilárias por pelo menos 5 anos (PAILY; HOTI; DAS, 2009).

A periodicidade da microfilaremia obedece a três padrões distintos, dependendo da localização da população hospedeira no mundo. São elas: período 
noturno, com picos de filaremia entre 22 h e 1 h; período noturno subperiódico, com microfilárias aparecendo em todo o dia, sendo porém a maior concentração no período noturno; e periódica diurna com microfilaremias durante todo o dia, com picos entre as 12 h e $20 \mathrm{~h}$ (PAILY; HOTI; DAS, 2009) (Quadro 2).

Quadro 2 - Tabela da periodicidade das microfilárias em relação à geografia do parasito

\begin{tabular}{|l|l|l|}
\hline Parasito & Forma periódica & Ocorrência \\
\hline W. bancrofti & Periódica Noturna & $\begin{array}{l}\text { Asia, África, } \\
\text { Malásia, Filipinas, } \\
\text { Américas }\end{array}$ \\
\hline W. bancrofti & Noturno subperiódico & Tailândia \\
\hline W. bancrofti & Periodidicidade Diurna & $\begin{array}{l}\text { Pacífico Sul, Ilhas } \\
\text { Nicobar e } \\
\text { Andaman }\end{array}$ \\
\hline B.malayi & Periodicidade Noturna & $\begin{array}{l}\text { Índia, China, } \\
\text { Malásia, } \\
\text { Indonésia, } \\
\text { Filipinas, Japão e } \\
\text { Coreia }\end{array}$ \\
\hline B.malayi & $\begin{array}{l}\text { Noturno } \\
\text { Subperiódica }\end{array}$ & $\begin{array}{l}\text { Malásia, } \\
\text { Indonésia, } \\
\text { Filipinas }\end{array}$ \\
\hline B.timory & Periódica Noturna & Ilhas do Timor \\
\hline
\end{tabular}

Fonte: Payli, Hoti e Das, 2009 modificada

No Brasil, a periodicidade da microfilaremia é noturna, com horários de pico entre $22 \mathrm{~h}$ e $1 \mathrm{~h}$, coincidindo com a ocorrência de maior atividade hematofágica do mosquito, o C. quinquefasciatus, o que contribui para o aumento da infecção e transmissão da doença (FONTES et al., 2000; FREEDMAN; NUTMAN, 1989).

Chandra (2008) demonstrou que existe uma correlação entre as taxas de transmissão e o sincronismo entre o período de maior proliferação do vetor, a temperatura, umidade do ar e a evolução das formas larvais da $W$. bancrofti. Nos períodos onde a umidade do ar e temperaturas favorecem a proliferação do vetor, muitas vezes não coincide com o melhor período de desenvolvimento das formas 
larvais L2 para L3, podendo ser tão longo quanto 6 semanas, inviabilizando dessa forma a transmissão do parasita (CHANDRA, 2008).

Figura 4 - Momento da saída do parasito da probóscide do vetor na forma larval L3 para infectar o ser humano (400x).

Fonte: Fontes e Rocha, 2005

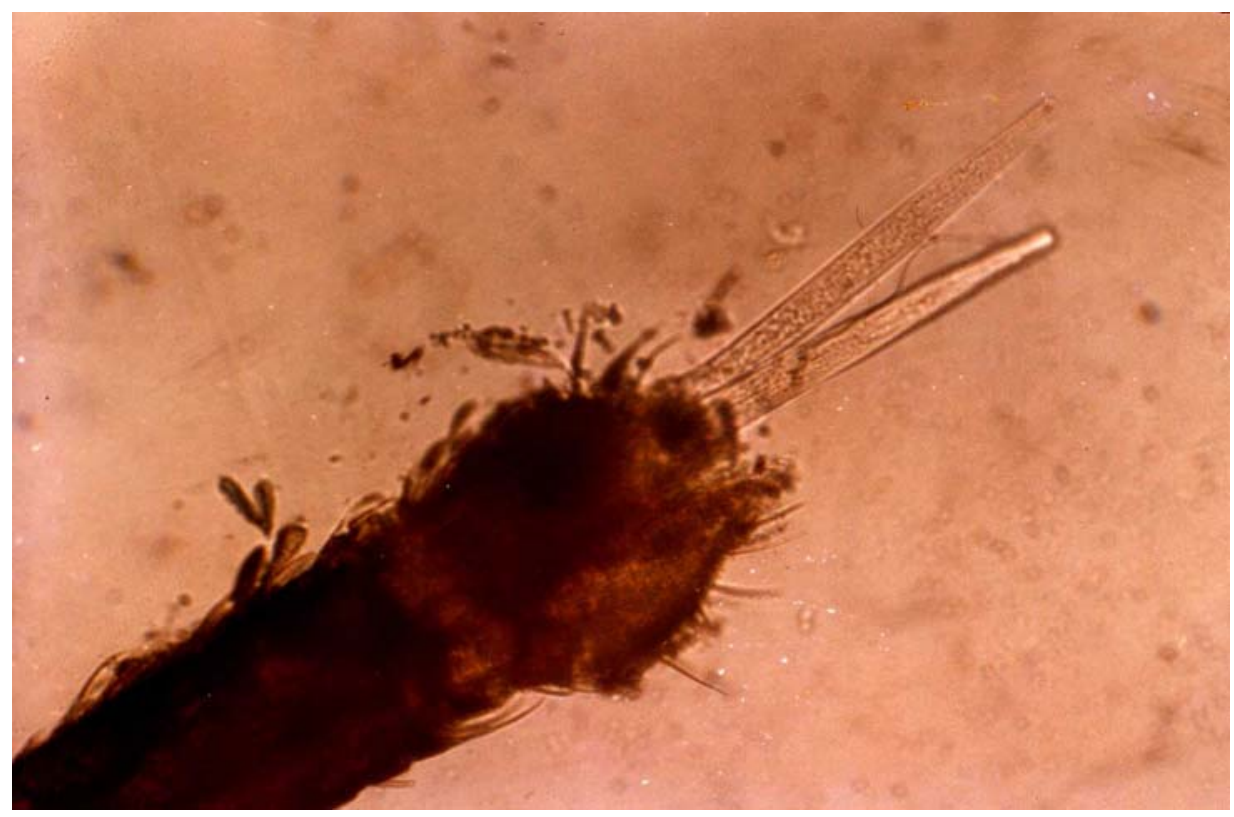

Figura 5 - Larva infectante $\left(L_{3}\right)$ de $W$. bancrofti junto à probóscide de fêmea de $C$. quinquefasciatus (400X).

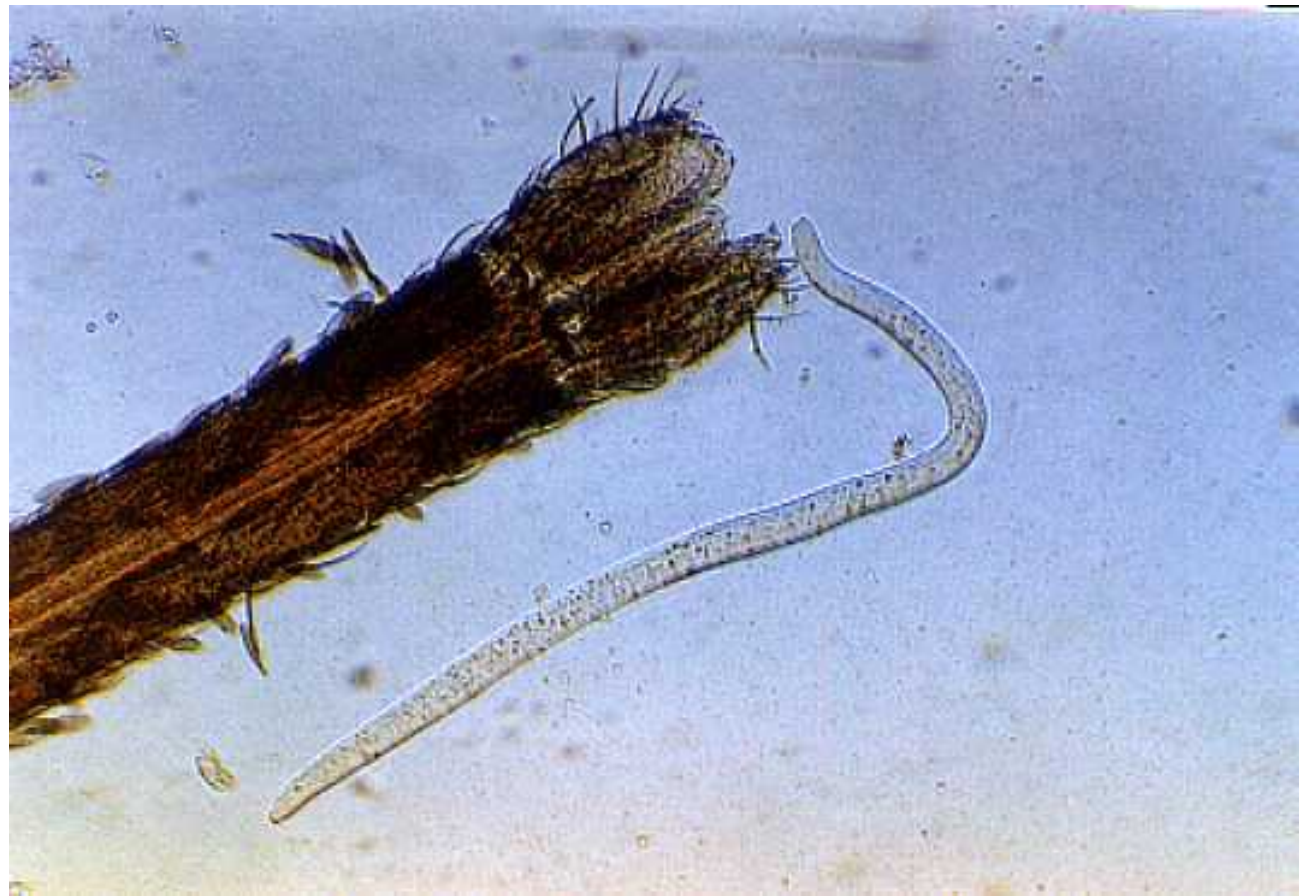

Fonte: Fontes e Rocha, 2005 
Figura 6 - Ciclo de Vida da W.bancrofti

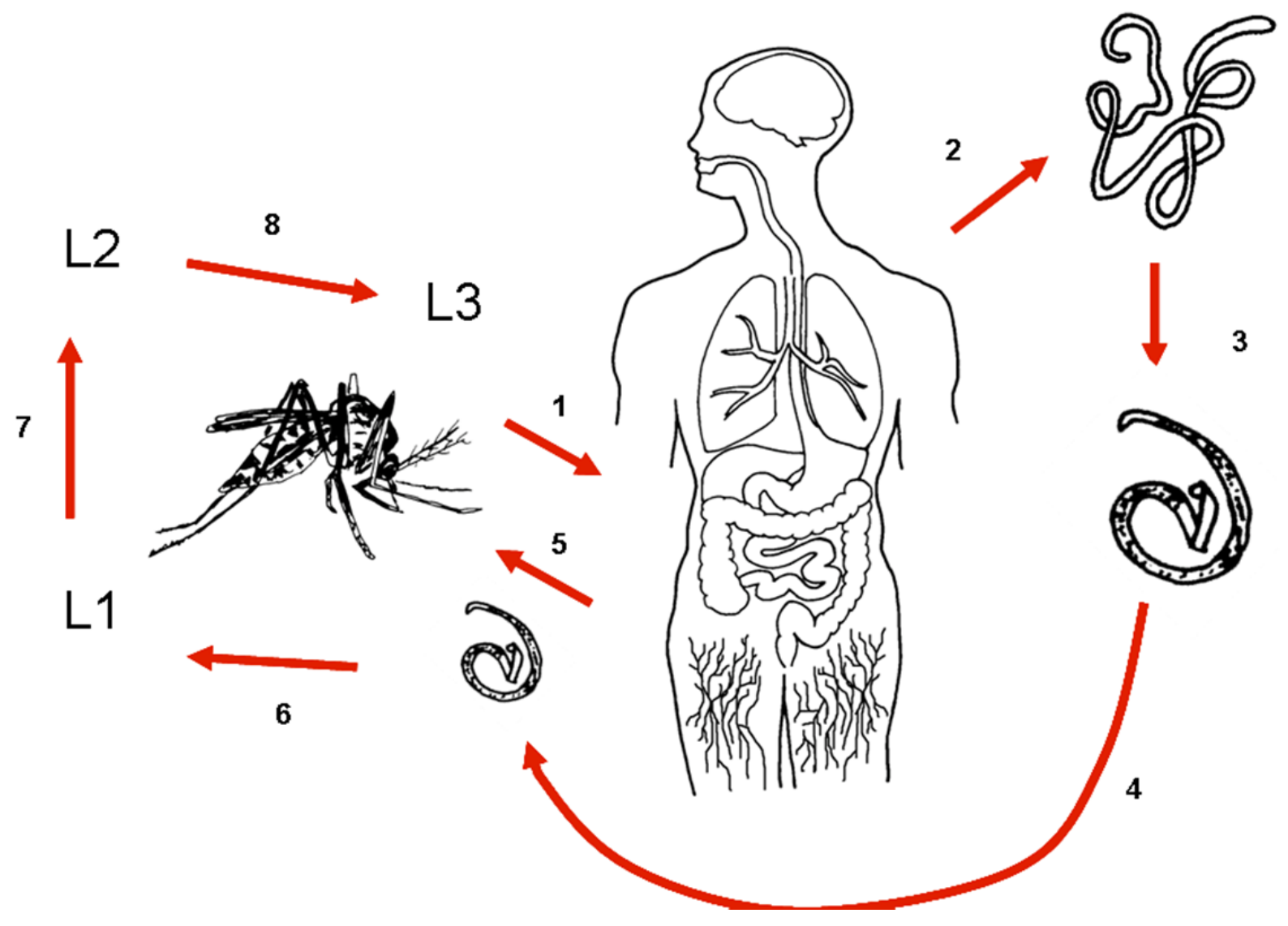

1. Mosquito infecta homem com larvas L3 durante o repasto; 2 . Desenvolvimento das formas larvais para verme adulto e estabelecimento dos vermes adultos nos vasos linfáticos; 4. Reprodução e liberação das microfilárias na circulação periférica; 5.Ingestão das embrionárias ou microfilárias pelo mosquito; 6 . Migração das formas larvais ingeridas pleo trato gastrointestinal e musculatura torácica e evolução para L1; 7 . Evolução de L1 para L2; Evolução de L2 para L3 e migração da forma L3 para a probóscide e cabeça do mosquito. Fonte: Barbieri, $2010^{1}$

\subsubsection{Vetor}

$\mathrm{Na}$ Ásia, América Central e América do Sul, dentre as várias espécies causadoras da filariose linfática $W$. bancrofti é a mais frequente, respondendo por mais de $90 \%$ de todos os casos da doença no mundo, cujos vetores são: o Culex, Anopheles, Aedes e Mansonia dependendo da região (RAMACHANDRAN, 1970;

\footnotetext{
1 Barbieiri,F. Arquivos pessoais, 2010.
} 
SASA, 1976)

O Culex é o principal vetor nas regiões onde a microfilaremia periférica é noturna, pois coincide com o seu período de hemofagia, e também é o mosquito que ingere a maior quantidade de sangue (ALBUQUERQUE et al., 1999; CALHEIROS et al.,1998), o que significa, em patamar de igualdade, que ingere um número maior de microfilárias.

A suscetibilidade do vetor à infecção filarial depende de três fatores: o genético, o fisiológico e o físico, sendo que qualquer falha numa dessas etapas impede o processo de penetração e/ou evolução das microfilárias no mosquito.

A primeira delas é denominada de barreira do trato gastrointestinal. A armadura do aparelho cibarial em alguns mosquitos é bem desenvolvida e pode causar lesão na microfilária durante o repasto, diminuindo a transmissão (APUD McGREEVY et al., $1978^{2}$ apud SERRÃO; LABARTHE; LOURENÇO DE OLIVEIRA, 2001; COLUZZI; TRABUCCHI, 1968).

A segunda forma de barreira é a velocidade da coagulação do sangue no trato digestivo dos mosquitos, que varia de espécie para espécie. A coagulação do sangue, antes que ocorra a migração da microfilária para o tórax, impede o seu desenvolvimento (KARTMAN, 1953; EWERT, 1965).

A terceira forma de barreira é a característica da membrana peritrófica que é mais espessa em algumas espécies de mosquito, o que diminui a capacidade de migração das microfilárias do trato gastrointestinal para o tórax (PAILY; HOTI; DAS, 2009).

A carga filarial nos hospedeiro humano também é fator de sobrevivência no mosquito vetor (KRISHNAMOORTHY et al., 2004), uma vez que altas taxas de filaremia podem provocar a morte do vetor tanto pelo número de filárias ingeridas como pela reinfecção do vetor, indicando que existe uma resposta imunológica do vetor à contaminação pela microfilária(PAILY; HOTI; DAS, 2009)

No Brasil, o único hospedeiro transmissor da filariose linfática é o mosquito C. quinquefasciatus (Say, 1823), da ordem Diptera, família Culicidae, considerado um dos vetores mais eficientes na transmissão desse filarídeo, dentre os de sua espécie. (PAILY; HOTI; BALARAMAN, 2006).

\footnotetext{
${ }^{2}$ McGREEVY, P. B.; BRYAN, J. H.; OOTHUMAN, P.; KOLSTRUP, N. The lethal effects of the cibarial and pharyngeal armatures of mosquitoes on microfilariae. Trans. R. Soc. Trop. Med. Hyg., v. 72, n. 4, p. 361-368, 1978.
} 
Em estudo realizado por Calheiros et al., em 1998, demonstrou-se que o mosquito $C$. quinquefasciatus foi mais eficiente na maturação das larvas de $W$. bancrofti quando comparado com o Aedes aegypti. Isso se deve ao fato de que tanto a periodicidade das microfilárias como o hábito de hemofagia do Culex são noturnos. Ao contrário, Aedes tem hábito hemofágico diurno, o que por si só tornaria muito difícil a sua infecção por $W$. bancrofti, além de que mesmo com a infecção experimental do mosquito Aedes, não seria possível a transmissão do parasito pela incapacidade de evolução das formas larvais L1 para as formas infectantes.

A infecção dos mosquitos por microfilárias indicam que a mortalidade dos vetores pode aumentar em até 15 vezes quando existe a infecção. (KRISHNAMOORTHY et al., 2004).

Sobre o mecanismo de reprodução do mosquito C. quinquefasciatus, iniciase com a ovoposição em águas paradas e poluídas, encontrando nesse meio ambiente as condições perfeitas de proliferação, principalmente se houver infraestrutura precária de saneamento e esgoto (BARBOSA et al., 2007).

Figura 7 - Mosquito C. quinquefasciatus, também conhecido como carapanã, pernilongo ou muriçoca.

Fonte: Brasil, 2009. 


\subsection{Patologia e Quadro Clínico}

A ONU, por meio da Classificaçao Internacional de Distúrbios da Função e Saúde, tornou-se instrumento de reconhecimento internacional das diversas desordens da saúde. Por assim ser, considera a filariose linfática a segunda maior causa de doenças incapacitantes no mundo, perdendo apenas para as desordens mentais (ZELDENRYK et al., 2011).

A filariose linfática é uma doença deformante, que causa edema linfático, alterando o nível de capacidade do indivíduo na realização de suas tarefas diárias. Afeta a mobilidade (linfedema de membros, dificuldade de locomoção), causa incapacidade para manter relações sexuais (hidrocele), com impacto psicológico elevado e diminuição da autoestima, levando à depressão (ZELDENRYK et al., 2011).

A doença linfática possui formas clínicas e subclínicas. Aproximadamente 2/3 dos doentes apresentam formas subclínicas, entretanto, quando examinados e realizados exames, constata-se a presença de imunossupressão e alterações da função renal. O terço restante apresenta as formas clínicas da doença, que são a elefantíase e as linfangites (SHENOY et al., 2008).

Nos últimos anos, houve um incremento no conhecimento da fisiopatologia da filariose linfática. Essa evolução permitiu uma abordagem clínica mais acurada e terapêutica dos pacientes, principalmente no reconhecimento das duas síndromes agudas: a Linfangite Aguda Filarial (LAF) e a Dermatolinfoangioadenite Aguda (DLAA) (SHENOY et al., 2008).

A LFA é causada pela reação inflamatória que decorre da morte de vermes adultos após o tratamento, enquanto que a DLAA é causada pela dilatação dos vasos linfáticos e pelas reações inflamatórias causadas pelas substâncias imunomoduladoras produzidas pelos vermes adultos (SHENOY et al., 2008).

Os quadros de LAF são caracterizados por febre, cefaléia, e dor local imediatamente após o tratamento. A DLAA é caracterizada por febre, calafrios, cefaleia, dor na área afetada e vômitos e, nos casos mais severos, toxemia, alterações dos níveis de consciência e incontinência urinária. Esse quadro clínico mais exacerbado é frequente nos casos agudos de linfedema.

Ambos apresentam processo inflamatório local, dor, calor, rubor, edema e aumento da temperatura local. As cadeias ganglionares adjacentes ficam 
engurgitadas. Os sintomas clínicos locais são de linfangites, linfoadenites, celulite e até formação de abscessos (SHENOY et al., 2008).

Os pacientes portadores das formas assintomáticas, com lesão nos vasos linfáticos, classificam-se como portadores da forma sub-clínica da doença (DREYER; DREYER; PIESSENS, 1999).

Na sua forma crônica, a filariose é responsável pelas principais alterações físicas e incapacitantes do paciente, principalmente nos casos de elefantíase - que decorre das reinfecções recorrentes da área com linfangiectasias (Figura 8).

Figura 8 - Paciente apresentando elefantíase de membro inferior.

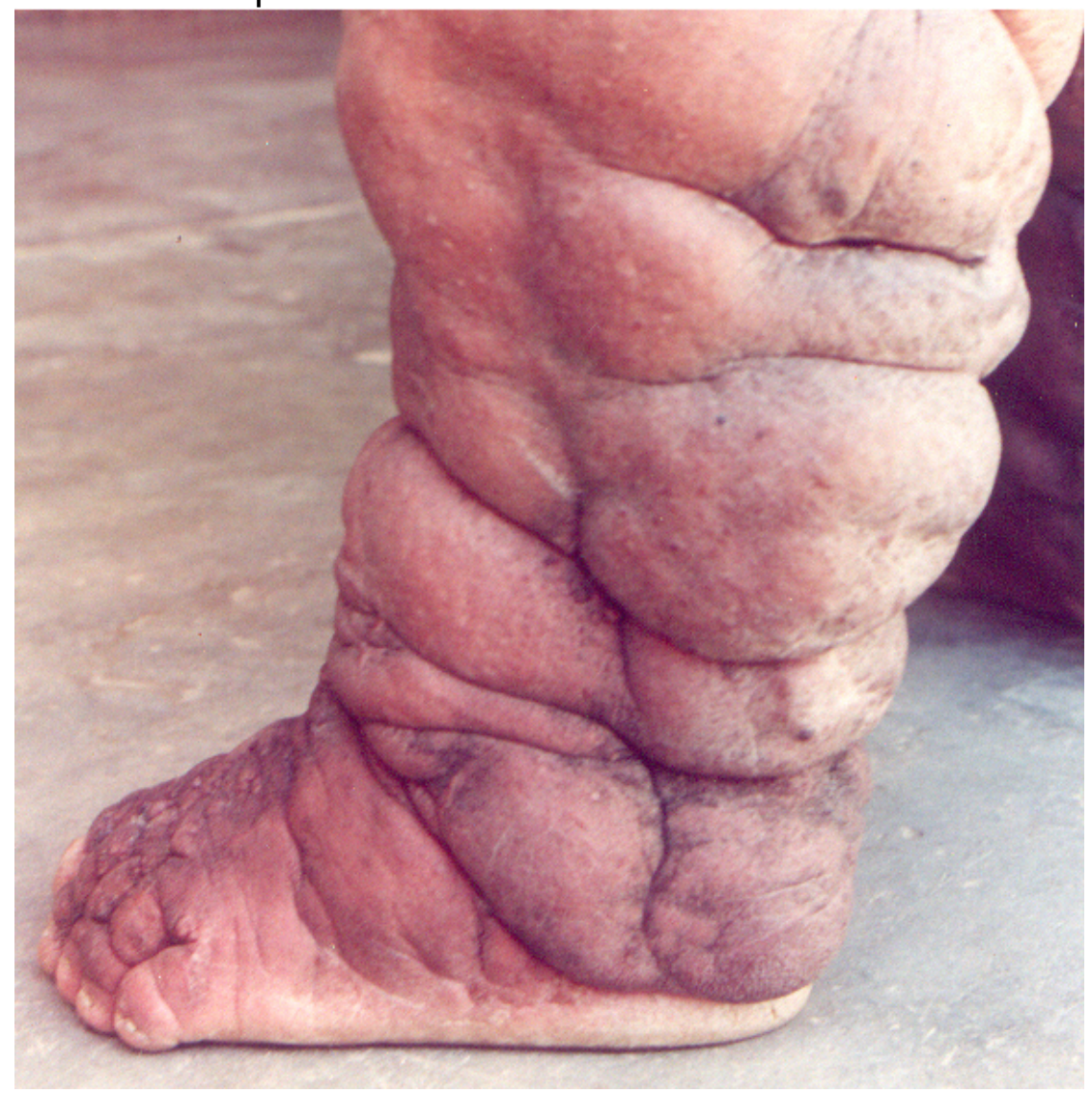

Fonte: da Fontes; Rocha ${ }^{3} 2002$

A filariose linfática, quando localizada em outros órgãos, apresenta diferentes manifestações clínicas. Acredita-se que essas alterações são causadas não pelos vermes adultos, mas pelas microfilárias ou por produtos difusíveis dos parasitas ou ainda por complexos autoimunes. Todas essas formas são

${ }^{3}$ Fontes, G.; Rocha,E.M.M. Arquivos pessoais. 2002 
progressivas, não afetam todos os indivíduos de maneira igual, porém, a evolução para as formas graves, se não tratada, é inexorável (PFARR et al., 2009).

Outras formas clínicas da filariose, além das LAF e DLAA, são: artrite, doença renal, linfedema, hidrocele, quilúria, eosinofilia pulmonar tropical, fibrose endomiocárdica tropical e rash cutâneo.

\subsubsection{Artrite}

As artrites são reconhecidas como manifestações da doença filarial, causada pela ruptura de alguns vasos linfáticos dentro da articulação, ou por reação inflamatória (DAS; SEN, 1968). Existem dois tipos diferentes: a manifestação oligoarticular, mais rara, que afeta grandes articulações, como os joelhos, e a pluriarticular, rara na filariose bancroftiana, mas frequente na mansonelose e a oncocercose. As manifestações clínicas são decorrentes do depósito de complexos autoimunes no espaço articular. (DISSANAYAKE; GALAHITIYAWA; ISMAIL, 1982).

O diagnóstico de ambas artrites pode ser por meio de exames clínicos e pela pronta resposta ao uso da dietilcarbamazine (DEC).

\subsubsection{Doença Renal}

Glomerulonefrites, hematúria e proteinúria são as principais manifestações de doença renal nos portadores de filariose linfática. Cerca de $45 \%$ dos pacientes não tratados apresentam doença renal; 35\% podem apresentar lesões renais que se manifestam por hematúria microscópica, e 20\% apresentam hematúria e/ou proteinúria. Acredita-se que a patogenia dessas alterações seja decorrente do depósito de complexos autoimunes no glomérulo renal, confirmadas somente em pacientes portadores de oncocercose. (DREYER; DREYER; PIESSENS, 1999).

\subsubsection{Linfedema e Hidrocele}

Como já mencionado, as formas crônicas da filariose, o linfedema e a hidrocele, aparecem respectivamente em $12,5 \%$ e $21 \%$ em pacientes do sexo masculino. A patogenia da dilatação linfática inicial é decorrente da presença do parasita, podendo progredir até 1,2 mm por ano (DREYER et al., 2002). 
A progressão da doença ocorre pelas infecções bacterianas repetidas, agravando o edema linfático. Debrah et al. (2009) entendem que a hidrocele está associada à presença de um polimorfismo do nucleotídeo promotor da VEGF-A (vascular endothelial growth factor $A$ ) que leva à produção de mais VEGF-A. Entretanto, há autores que entendem que a hidrocele tem outros mecanismos fisiopatológicos e que a Wolbachia sp. é um dos prováveis estimuladores da produção desta proteína, acentuando o quadro clínico dos pacientes, mas que ao ser tratada, apresenta uma melhora no quadro clínico da hidrocele. (Figura 9).

Figura 9 - Paciente com hidrocele de origem filarial

Fonte: Fontes e Rocha, $2003 .{ }^{4}$

\subsubsection{Quilúria}

A quilúria caracteriza-se pelo aumento da pressão do sistema linfático após a ingestão de alimentos pelo indivíduo, principalmente aqueles gordurosos. $O$ aumento da pressão em um sistema linfático já dilatado pode romper esses vasos, levando à passagem de linfa para o sistema excretor renal (DREYER; MATTOS; NORÕES, 2007). O quadro clínico é seguido de astenia e emagrecimento. Há relatos de hematúria micro e macroscópica, e dificuldades urinárias associadas à presença de microfilárias na urina, nos casos agudos da doença.

\footnotetext{
${ }^{4}$ Fontes, G.; Rocha,E.M.M. Arquivos pessoais. 2004
} 
A presença de microcalcificações no parênquima renal é outro sinal de quilúria, decorrentes da calcificação das microfilárias mortas no sistema renal, podendo a mesma ser intermitente.

\subsubsection{Eosinofilia Pulmonar Tropical}

É uma patologia que ocorre em pequena porcentagem de pacientes, principalmente do sexo masculino, caracterizada por crises de bronquite asmática noturnas, tosse, anorexia e perda de peso. Concentra-se na Índia e sudoeste asiático, aparecendo como resposta inflamatória às microfilárias de $W$. bancrofti e $B$. malayi.

Decorre de reação imunológica à microfilária quando são destruídas nos pulmões, com resposta celular mediada por eosinófilos.

As provas de função pulmonar revelam doença pulmonar restritiva com moderada obstrução. $O$ raio $X$ de tórax apresenta infiltrado reticular difuso (Figura 10). O hemograma apresenta eosinofilia com altas concentrações de anticorpos IgG e $\operatorname{lgE}$, antifilárias específicos. A produção contínua das microfilárias pelos vermes adultos caracterizam a cronicidade dessa doença. $O$ tratamento com DEC melhora a sintomatologia, entretanto, o paciente pode apresentar cronicidade dos sintomas por fibrose pulmonar. (PINKSTON et al., 1987).

\section{Figura 10 - Pneumonia eosinofílica crônica idiopática.}
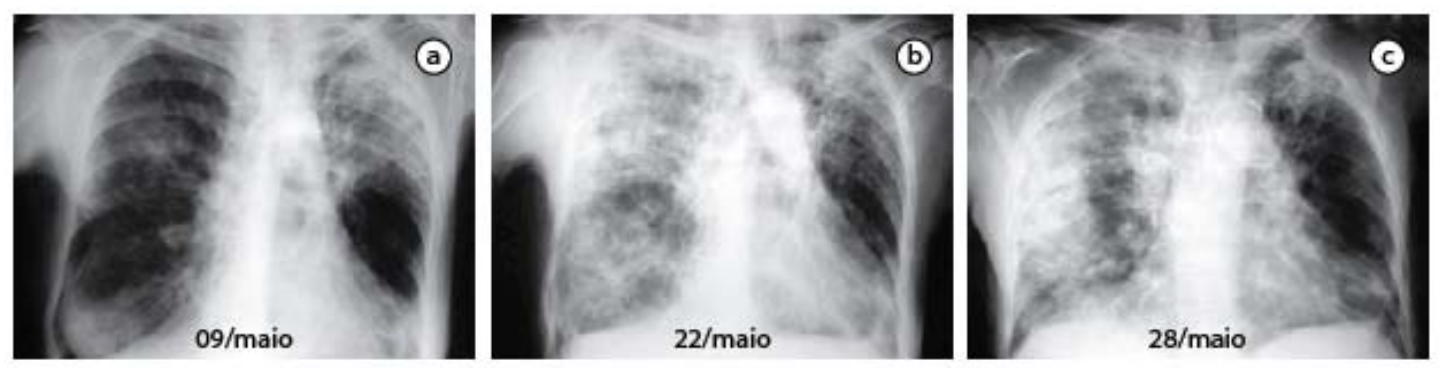

Paciente de 71 anos, feminina, asmática, com sinais de comprometimento sistêmico. Eosinófilos no sangue de $29 \%\left(4.234\right.$ células $\left./ \mathrm{mm}^{3}\right)$. Radiografias de tórax (a-c) mostram infiltrado pulmonar migratório, caracterizado por consolidação do espaço aéreo com distribuição periférica ao longo da pleura.

Fonte: Campos e Pereira, 2009. 


\subsubsection{Fibrose Endomiocárdica Tropical}

A fibrose endomiocárdica tropical é a resposta inflamatória celular mediada por eosinófilos que causam a lesão endocárdica. Manifesta-se por cardiopatia restritiva. Há formação de trombos intramurais com fibrose endocárdica, arritmias e pericardites com ou sem derrame (FRANCO-PAREDES et al., 2007)

\subsubsection{Granuloma Filarial}

Granulomas envolvendo e contendo microfilárias já foram observados em vários órgãos, tais como a pele e tecido celular subcutâneo. Eles são extremamente raros e quase não causam sintomas (DREYER; DREYER; PIESSENS, 1999).

\subsubsection{Rash Cutâneo}

Rash cutâneo é um exantema que se apresenta de forma inespecífica na filariose bancroftiana(NUTMAN et al., 1986).

\subsection{Diagnóstico}

Para se determinar quais os melhores testes no diagnóstico da filariose em seres humanos e no mosquito vetor, deve-se levar em conta a operacionalidade, sensibilidade, a especificidade e a acurácia. Ou seja, a escolha do método diagnóstico da filariose deve ser a mais compatível, levando-se em conta as condições locais de realização, armazenamento e processamento de dados, sob o risco de obtenção de dados incorretos ou não consistentes.

Em estudos de campo e em inquéritos epidemiológicos, deve-se seguir rigorosamente os métodos e protocolos convencionados, pois não raras vezes, as condições contextuais acabam por redundar em limitações logísticas e em contaminação das amostras coletadas.

Outros fatores importantes no correto diagnóstico dizem respeito à refrigeração apropriada no armazenamento dos cartões do Imuno Cromographic Test (ICT), e transporte adequado das lâminas para o laboratório nos testes da gota 
espessa que, desde que corretamente utilizados, reduzem os custos e tornam a pesquisa mais segura (GASS et al., 2012).

\subsubsection{Exame Microscópico da Gota Espessa de Sangue}

Consiste na coleta de 20 a $100 \mu$ de sangue capilar, através da punção digital (Figura 11.a e 11.b). Nos países onde a microfilaremia ocorre no periodo noturno, o horário da coleta varia entre 22 h e $1 \mathrm{~h}$, como é o caso do Brasil.

É uma das técnicas mais simples de execução, é uma das mais utilizadas em inquéritos epidemiológicos de massa, por seu baixo custo, além de indicada quando ocorre a presença de doenças causadas por diferentes espécies de filarídeos (FONTES; ROCHA, 2005; WHO, 2007), permitindo o diagnóstico diferencial entre elas.

Figura 11.a - Preparo da punção digital com lanceta.

Fonte: Brasil, 2009 
Figura 11.b - Gota de sangue formada após a lancetagem, pronta para coleta.

Fonte: Brasil, 2009

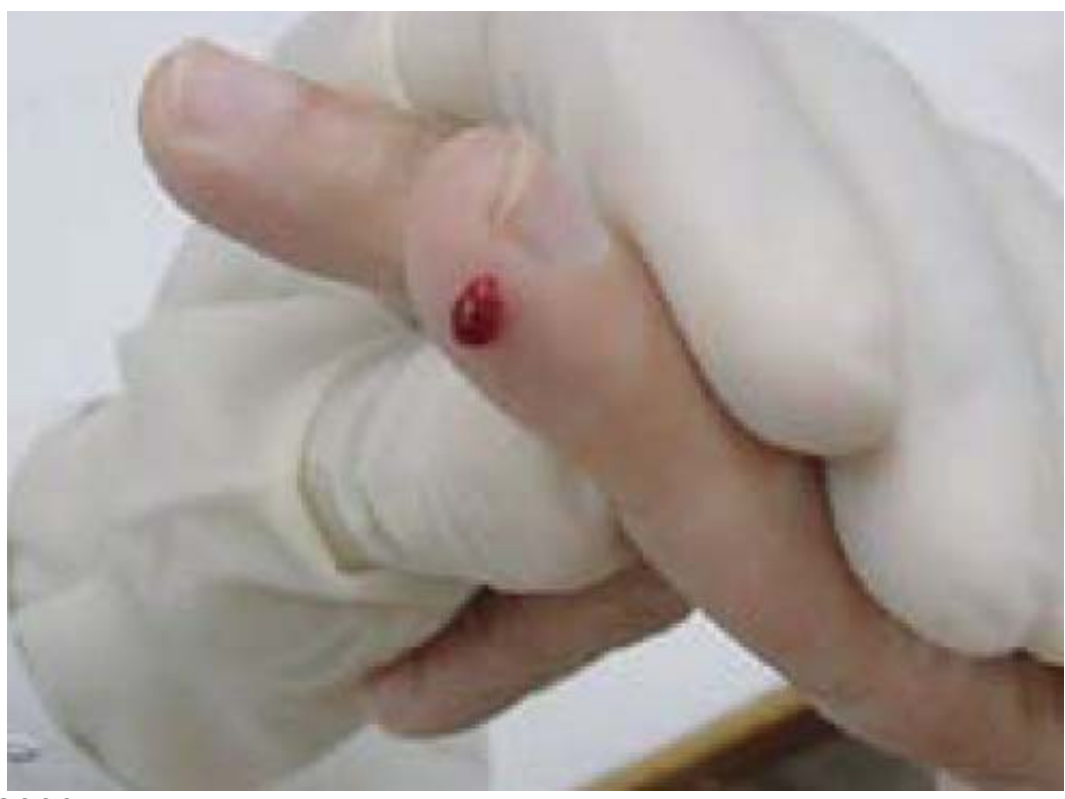

No exame da lâmina pela gota espessa, as diferenças morfológicas dos diferentes filarídeos que produzem microfilárias diz respeito à presença ou ausência de núcleos na cauda (NC) e lou na presença ou ausência de bainha (SH) (Figura12)

Figura 12 - Diferenciação das espécies de microfilárias com base na presença ou ausência de núcleos na cauda (NC) e na presença ou ausência de bainha (SH-sheath).

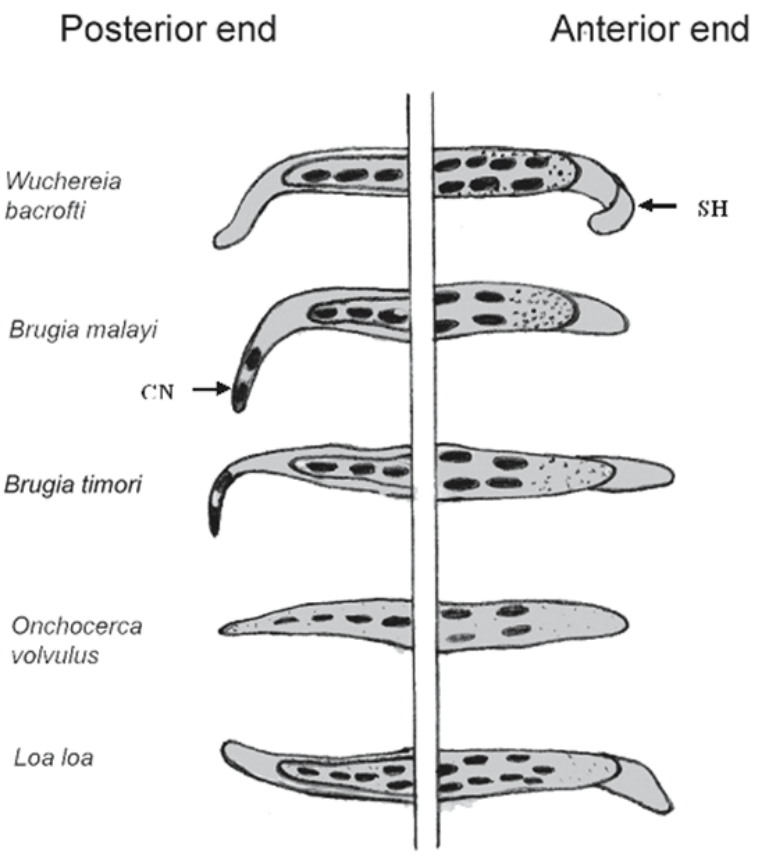

Fonte: Paily, Hoti e Das, 2009. 
A sensibilidade deste teste relaciona-se à quantidade de microfilárias no sangue, apresentando maior suscetibilidade em pacientes com mais do que 10 $\mathrm{mf} / \mathrm{mL}$ (FONTES et al., 1996), na porcentagem de $98,5 \%$, e de $60 \%$ em indivíduos com menos de $10 \mathrm{mf} / \mathrm{mL}$.

Por ser um teste qualitativo e diagnóstico, o Ministério da Saúde (BRASIL, 2008) reconhece que o mesmo pode ser quantitativo quando utilizados capilares mensurados que determinam o volume de sangue empregado na confecção das lâminas. Esse teste é denominado de Gota Espessa Mensurada e consegue estimar a microfilaremia em cada paciente.

\subsubsection{Filtração de sangue em membrana de policarbonato}

O exame da filtração de sangue em membrana de policarbonato foi desenvolvido por Chularerk e Desowitz em 1970. O objetivo deste teste é aumentar a sensibilidade do teste da gota espessa em indivíduos portadores de microfilaremia. (CHULARERK; DESOWITZ, 1970).

Utiliza-se membranas de policarbonato com poros de $3 \mu \mathrm{m}$ a $5 \mu \mathrm{m}$ de diâmetro, apropriados para reter as microfilárias que eventualmente estejam presentes na amostra de sangue, e não retém elementos figurados do sangue, o que facilita a leitura do resultado (FONTES; ROCHA, 2005).

A técnica de membrana de policarbonado utiliza até $10 \mathrm{~mL}$ de sangue em cada leitura. É o teste de escolha, padrão ouro, para avaliar a eficácia e controle do tratamento de indivíduos parasitados (DREYER et al., 1994; FONTES et al., 2005), e é 8,6 vezes mais sensível que o teste da gota espessa.

Entretanto, esta técnica é dificultosa quando comparada à da gota espessa, ainda que apresente maior sensibilidade, tendo em vista que requer a coleta de $10 \mathrm{~mL}$ de sangue por punção venosa, o que demanda técnicos especializados, armazenamento de sangue, elevando custos e tempo para a execução (WEIL; LAMMIE; WEISS, 1997).

\subsubsection{Testes Imunológicos}

Os testes imunológicos baseiam-se na dosagem de anticorpos (Ac) antifilariais (Bm 14, PanLF, Urina SXP, WB rapid) e antígenos (Ag) parasitários (ICT 
e Og4C3).

A desvantagem da pesquisa de anticorpos séricos é não permitir a distinção entre os indivíduos que foram doentes, que são doentes e aqueles que só tiveram contato com o parasita, mas sem desenvolver a doença (PIESSENS; PARTONO, 1980; WHO, 1992).

A grande vantagem da pesquisa de Ac ou Ag é que a mesma pode ser realizada em qualquer horário, sem preocupação com o ritmo de aparecimento das microfilárias na circulação periférica.

São dois os testes imunológicos mais utilizados: (i) o teste da imunocromatografia rápida (ICT), que se baseia na pesquisa de $\mathrm{Ag}$ do parasito a partir da utilização de Ac monoclonal AD12, o qual reconhece um Ag excretado pelos vermes adultos da $W$. bancrofti, e (ii) o ensaio imunoenzimático (ELISA) de pesquisa de Ag com a utilização de Ac monoclonal Og4C3, padronizado a partir do Ag do filarídeos bovino Onchocerca gibsoni (MCCARTHY et al., 2000).

A técnica de ICT permite o diagnóstico qualitativo, enquanto o teste de ELISA possibilita a quantificação do antígeno presente no sangue (semiquantitativo).

O teste de pesquisa de $\mathrm{Bm} 14$ é um teste imunoenzimático (ELISA) que determina a reação antifilarial do anticorpo recombinante Bm14 (RAHMAH et al., 2007).

Outros testes para pesquisa de Ac antifilarial são: o teste rápido denominado Rapid PanLF e o WB rapid (NOORDIN et al., 2007).

O PanLF consiste em um teste que apresenta 3 linhas, sendo uma de controle, uma com antígeno recombinante BmSXP e outra com o antígeno BmR1. Sua sensibilidade é de $91 \%$ para a detecção de filariose bancroftiana (NOORDIN et al., 2007).

O BmSXP é um antígeno recombinante derivado do gene SXP1. A especificidade para $W$. bancrofti é de 91\% (NOORDIN et al., 2007).

O BmR1 é um antígeno recombinante derivado do gene Bm17DIII, e é utilizado no teste rápido para pesquisa de $B$. malayi e $B$. timori, com especificidade maior que 99\% e sensibilidade maior que 95\% (NOORDIN et al., 2007).

Concluindo, a Imunocromatografia (ICT) e a sorologia são métodos mais sensíveis e podem diagnosticar filaremias sub-patentes; porém, seus custos operacionais - 100 vezes mais caros que a gota espessa - na maioria das vezes, 
dadas as características econômico-sociais do estudo, transforma-se em fator impeditivo para a realização de estudos de campo em grande escala.

\subsubsection{Reação em Cadeia da Polimerase (PCR)}

Os testes envolvendo marcadores de DNA são testes com alta sensibilidade e especificidade, podendo detectar DNA do parasito tanto no vetor como no homem, quer para W.bancrofti como para B. malayi e B. timori (Mc CARTHY et al., 2000).

A sequência frequentemente utilizada como molde para a pesquisa de DNA da W. bancrofti é a Sspl. Trata-se de uma sequência repetitiva, com 188 pb, encontrada no genoma do parasito, que por sua vez é reconhecida e copiada de forma exponencial durante a PCR, a partir da utilização dos iniciadores (primers) NV1 (5'-CGTGATGGCATCAAAGTAGCG-3') e NV2 (5'CCCTCACTTACCATAAGACAA-3') (ZHONG et al., 1996).

O diagnóstico da bancroftose obteve um importante incremento com a padronização da PCR, uma vez demonstrada a possibilidade da utilização de diversos fluídos biológicos para fins de diagnóstico, como sangue, urina ou escarro, (ABBASI et al., 1999; LUCENA et al., 1998; WILLIAMS et al., 1996), assim como no diagnóstico da presença do parasito no vetor.

Em estudos realizados por McCarthy et al., em 1996, ficou demonstrado que a sensibilidade do teste foi positiva em 40 dos 42 pacientes pesquisados, somente negativa em dois pacientes com microfilaremias abaixo de $1 \mathrm{mf} / \mathrm{mL}$.

O teste da PCR mostra-se sensível em $88 \%$ dos casos e $100 \%$ específico nos pacientes com microfilaremias maiores do que $8 \mathrm{mf} / \mathrm{mL}$, quando utilizados volumes de $100 \mu \mathrm{L}$ (WILLIAMS et al., 1996). Nos indivíduos com microfilaremias muito baixas, aumentando-se o volume de sangue ao PCR de $100 \mu \mathrm{L}$ para $500 \mu \mathrm{L}$, a sensibilidade incrementou de $60 \%$ para $84 \%$. Estes resultados demonstram que o PCR está diretamente ligado à quantidade de parasitos no sangue, demonstrando ser uma forma de controle pós-tratamento.

\subsubsection{Ultrassom (USG)}

A realização de USG também pode confirmar a presença de vermes adultos 
no sistema linfático da região inguinoescrotal. A presença do verme vivo é patognomônico de filariose bancroftiana (AMARAL et al., 1994).

Nos quadros de dilatação linfática, mesmo com o tratamento com DEC e morte do parasita adulto, este quadro não regride. O USG não é indicado nesta fase da doença, uma vez que os vermes adultos não estão presentes.

\subsubsection{Linfocintilografia}

A injeção de albumina marcada ou dextran no espaço interdigital com uso de uma câmera de raios gama, pode determinar alterações no fluxo, dilatação, obstrução e acúmulo de linfa nos vasos linfáticos, ainda que em pacientes assintomáticos (PALUMBO, 2008). É um método sofisticado, caro e, portanto pouco utilizado.

\subsubsection{Diagnóstico vetorial}

Existem duas técnicas empregadas para o diagnóstico de filária no vetor: a) a dissecação; e b) a técnica da PCR.

A dissecação foi a técnica mais utilizada até pouco tempo atrás. Foi suplantada pela técnica da PCR, mas ainda preserva o seu valor, pois uma vez realizada, a visualização das formas larvais da microfilárias permite a quantificação e a identificação dos estágios larvais em que se encontram. Com isso, pode-se identificar o número de vetores infectados com larvas L3 e determinar a taxa de infectividade, que é a razão de vetores infectados com L3 pelo número de vetores totais (RAMACHANDRAN, 1970).

A técnica da PCR é a mais utilizada nos dias atuais. É mais sensível e pode processar um grande número de vetores ao mesmo tempo por ser capaz de detectar DNA de uma única larva de $W$. bancrofti em amostras que contenham até 100 mosquitos (FURTADO et al., 1997).

Goodman et al. (2003), utilizando as técnicas de PCR e dissecação de mosquitos, verificaram similaridade no resultado do diagnóstico vetorial entre ambas, porém, relatam que a PCR, assim como esperado, apresentava maior proporção no número de diagnósticos. 


\subsection{Tratamento}

O tratamento da filariose baseia-se nos efeitos da medicação sobre: a) as microfilárias; b) clareamento da antigenemia; c) efeito sobre as macrofilárias (vermes adultos); e d) prevenção das alterações e complicações clinicas da filariose. (SUMADHYA; CHATURAKA; SENAKA, 2011).

Atualmente, os fármacos utilizadas no tratamento de filariose linfática são dietilcarbazine (DEC), albendazol (ALB) e ivermectina (IVM), podendo ser utilizados separados ou conjuntamente.

O DEC permanece sendo a droga com melhor aceitação pela atividade microfilaricida e efeitos sobre os vermes adultos. A IVM tem atividade predominantemente microfilaricida e pouco macrofilaricida. O uso concomitante do ALB não está suficientemente estabelecido.

\subsubsection{DEC, IVM e ALB}

DEC é utilizada em doses de $6 \mathrm{mg} / \mathrm{kg}$, podendo ser utilizada em dose única ou em tratamento contínuo por 12 dias. Não existem diferenças de efetividade de tratamento entre essas duas formas.

O tratamento em dose única apresenta menores custos, menores efeitos colaterais, e maior adesão nos tratamentos em massa. O DEC atua principalmente sobre os vermes adultos. Seu mecanismo de ação ainda é controverso.

A associação de DEC com o ALB mostrou-se mais eficaz no combate e tratamento da filariose quando administrada dose única das drogas. A comparação da microfilaremia com 12 e 24 meses foi menor, estatisticamente significativa (BOCKARIE et al., 2007).

O uso de DEC está contraindicado nos países onde a oncocercose é endêmica, uma vez que os efeitos colaterais do tratamento da oncocersose com DEC são graves (AWADZl et al., 2003)

A ivermectina é uma droga que atua diretamente sobre as microfilárias. Com uma única dose, de 200 a $400 \mu \mathrm{g} / \mathrm{kg}$, e mesmo após um ano, os níveis de microfilaremia são reduzidos e comparam-se ao DEC. Não existe ação da ivermectina sobre os vermes adultos. Essa droga também é usada para o 
tratamento da oncocercose e tem ação sobre outros parasitas, tanto intestinais como pediculose e escabiose (PALUMBO, 2008).

Os efeitos do ALB levam à morte e destruição dos vermes adultos da filariose quando ministrado em doses de $400 \mathrm{mg}$, duas vezes ao dia, por 14 dias. A utilização de ALB com DEC ou IVM é recomendada no programa de eliminação de filariose da OMS (PALUMBO, 2008).

A utilização de um sal com DEC é tido como forma de controle da filariose em áreas endêmicas. Ele é seguro e não apresenta efeitos colaterais expressivos. Com a diminuição ou ausência de efeitos colaterais e atuando sobre a microfilaremia de forma paulatina, com poucas reações imunológicas, torna-se uma droga com ótimos resultados no combate à filariose (SUMADHYA; CHATURAKA; SENAKA, 2011).

Os sais fortificados de DEC são empregados em vários programas de controle da filariose ao redor do mundo. Seu uso é considerado mais efetivo na diminuição da microfilaremia se comparado às doses únicas de DEC, com efeito apenas sobre as microfilárias. Não atua sobre os vermes adultos (SUMADHYA; CHATURAKA; SENAKA, 2011).

\subsubsection{Tratamento Coletivos}

Múltiplas formas de tratamento e controle do MDA (Mass Drugs Administration) são utilizadas no controle das filarioses. Contudo, ainda não há um consenso em relação à maneira mais eficaz de tratar ou interromper a transmissão da doença.

Atualmente, o tratamento indicado na maioria dos países é a associação de DEC e IVM, exceto na África, onde ocorre a oncocercose. Esse tratamento representa um sério risco ao paciente portador da oncocercose, uma vez que as complicações do uso da DEC pode levar o paciente a óbito (AWADZI, 2003). A adição de IVM e ALB uma vez ao ano aumenta o tempo de supressão da microfilaremia. Na África, o tratamento ocorre com uma dose anual de IVM e ALB, incidindo em poucos efeitos colaterais e resultados satisfatórios (DEMBELE et al., 2010).

Dembele et al. (2010), observaram que o tratamento em massa permanece aberto a novas ideias e a novas formas de terapêutica, com o objetivo principal de 
cessar a transmissão e erradicar a doença mais rapidamente. Entendem que muito se tem a estudar para chegar a este objetivo, bem como aprender sobre qual medicamento, qual dose, por quanto tempo, e qual o melhor mecanismo de controle.

\subsubsection{Reações Adversas do Tratamento Coletivo}

O tratamento coletivo das populações de risco enfrenta problemas de adesão ante as reações adversas que podem surgir. Entre elas podemos citar febre, tremores, sonolência, náuseas, vômitos, dores de cabeça, letargia, eliminação de vermes e urticária. Reações maiores como linfangítes, abscessos, piora do linfedema e edema escrotal também podem ser encontrados.

Os efeitos colaterais afligem tanto homens quanto mulheres, acometendo cerca de $16,2 \%$ a $23,6 \%$ dos pacientes que recebem a dose usual de DEC, na proporção de $6 \mathrm{mg} / \mathrm{kg}$ (LIMA et al., 2012).

\subsubsection{Controles de Tratamento}

A avaliação da transmissão da filariose é realizada atualmente através de pesquisa de antígenos filariais nos seres humanos (ICT) e xenomonitoramento de vetores pela técnica da PCR nos mosquitos fêmeas ingurgitadas, possibilitando determinar se as medidas adotadas pelos Programas de Eliminação e Controle da Bancroftose estão sendo eficazes no controle da doença (FARID et al., 2007).

Uma vez que se encontrem parasitos nos vetores, constata-se a transmissão da filariose na área pesquisada.

No tratamento em massa, os mecanismos de controle devem ser mais específicos e sensíveis, porque a filaremia e a antigenemia diminuem, a primeira mais rapidamente e a segunda mais lentamente (KAZURA, 2010).

\subsubsection{Justificativa}

Histórico de filariose na região de Porto Velho e Guajará-Mirim.

Existência do vetor, o mosquito Culex quinquefasciatus. 
Foco da doença detectado por Rachou na década de 1950.

Nenhum outro estudo sobre a presença de filariose desde a década de 1960.

As condições socioeconômicas e climáticas semelhantes a de focos de filariose recentemente extintos na região amazônica. 


\section{OBJETIVO GERAL}

- Verificar a ocorrência de filariose bancroftiana e transmissão de W.bancrofti nas cidades de Porto Velho, Guajará-Mirim e Humaitá, da Amazônia Ocidental Brasileira.

\subsection{Objetivos específicos}

- Caracterizar o perfil clínico de pacientes com filariose bancroftiana em Porto Velho;

- Verificação da autoctonia dos microfilarêmicos encontrados. 


\section{METODOLOGIA}

\subsection{Equipe envolvida no estudo}

O presente estudo trata-se de um estudo de prevalência . $O$ trabalho foi realizado com auxílio de uma equipe multidisciplinar composta por técnicos pesquisadores do ICB-5/Monte Negro (RO), e alunos do curso de Medicina e de Biologia da Faculdade São Lucas, em Porto Velho (RO). Todos os técnicos e estudantes envolvidos receberam treinamento para a execução das atividades, sob a forma de curso, dentre eles o curso ministrado pela Prof. Dra. Maria Anice Mureb Sallum, da Faculdade de Saúde Pública da USP, com 80 h de duração, para a coleta e identificação dos mosquitos da família Culicidae. Outro curso foi o ministrado pelo Prof. Gilberto Fontes, da Universidade Federal de Alagoas, para a coleta de sangue, confecção da lâmina de gota espessa e identificação das microfilárias, com carga horária de $60 \mathrm{~h}$.

Ainda, os colaboradores foram orientados sobre a doença, formas de transmissão, diagnóstico e tratamento, assim como orientação para a condução do cadastramento dos moradores, preenchimento do questionário, aquisição do termo de consentimento Informado tanto de moradores das áreas ribeirinhas quanto escolares noturnos (APÊNDICES C e D) e para estarem sempre uniformizados, já que as coletas seriam realizadas a noite, o que facilitava a identificação dos participantes da equipe.

As atividades foram precedidas por campanhas de divulgação do trabalho em rádio, televisão e auxílio de lideranças nas comunidades das áreas estudadas com distribuição de cartilhas e folders explicativos sobre a doença (ANEXO A).

\subsection{Local do estudo}

O estudo foi realizado nos municípios de Porto Velho e Guajará-Mirim no estado de Rondônia e no município de Humaitá no Amazonas, nos quais foram realizados o levantamento geográfico das áreas que apresentaram os indicadores sintéticos ambientais (ISA) mais elevados para o desenvolvimento do vetor, nas cidades de Porto Velho, Guajará Mirim e Humaitá. 
As seguintes variáveis foram levadas em consideração, baseados na premissa de que $78 \%$ dos casos de filariose bancroftiana ao redor do mundo são encontrados em áreas com as seguintes características, que são semelhantes às áreas estudadas: a) proporção de domicílios sem água a partir da rede geral; b) proporção de domicílios sem esgotamento sanitário ligado à rede geral ou esgoto de águas pluviais; c) proporção de domicílios sem coleta de lixo; d) presença de dejetos ao ar livre (BONFIM et al., 2011) e, e) as áreas mais antigas da cidade (figura 14, $15,16,17)$.

Dentro das áreas consideradas com maior probabilidade de ocorrência do vetor, foram delimitadas áreas de maior e menor risco para a presença do vetor, sendo as residências escolhidas aleatoriamente para a visita dos técnicos para coleta do mosquito e de amostras para a confecção das lâminas. Foram definidas ás áreas de maior risco de propensão à proliferação do vetor e do parasito, como as residências localizadas justapostas às áreas de ácumulo de água paradas, depósitos de lixo e casas próximas ao Rio Madeira, e áreas de menor risco como as residências com distâncias maiores que 100 metros dessas áreas, excluindo-se como áreas de maior risco onde existe coleta de lixo.

As figuras 13,14, 15 e 16 demonstram as residências localizadas nas áreas da pesquisa com todas as características já mencionadas.

Figura 13 - Foto de casas do bairro Triângulo, área de pesquisa em Porto Velho Rondônia, 2008.

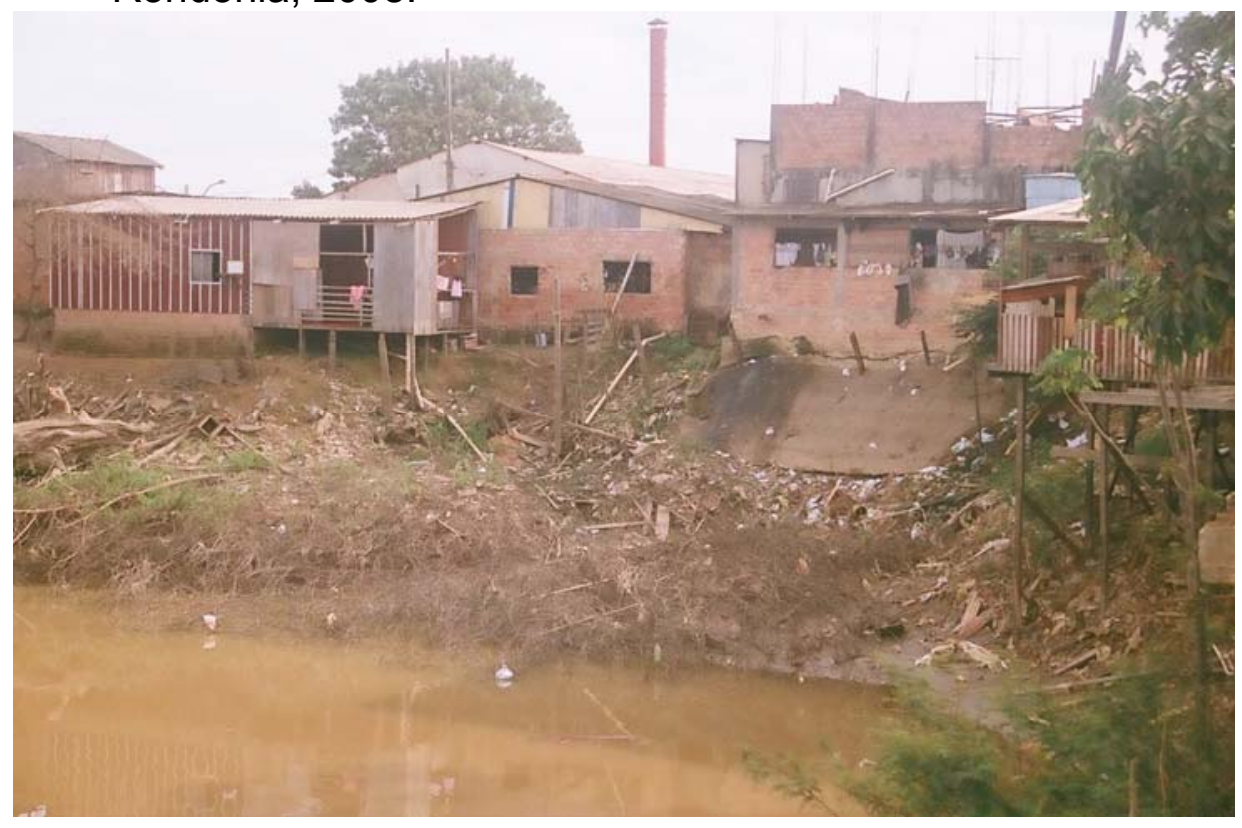


Fonte: Korte e Camargo $2008^{5}$

Figura 14 - Casa padrão em Guajará Mirim, Rondônia ,2009.

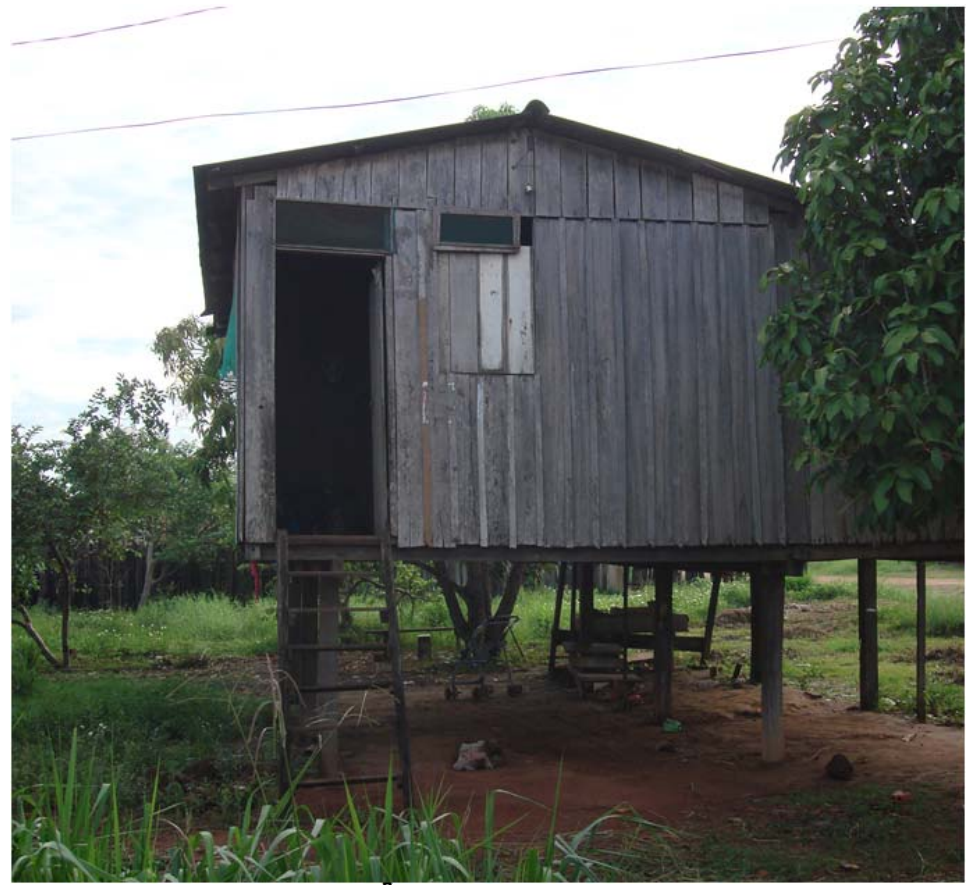

Fonte: Korte e Camargo, $2009^{6}$

Figura 15 - Bairro Comunidade Santo Antonio, Humaitá, Amazonas, 2009.

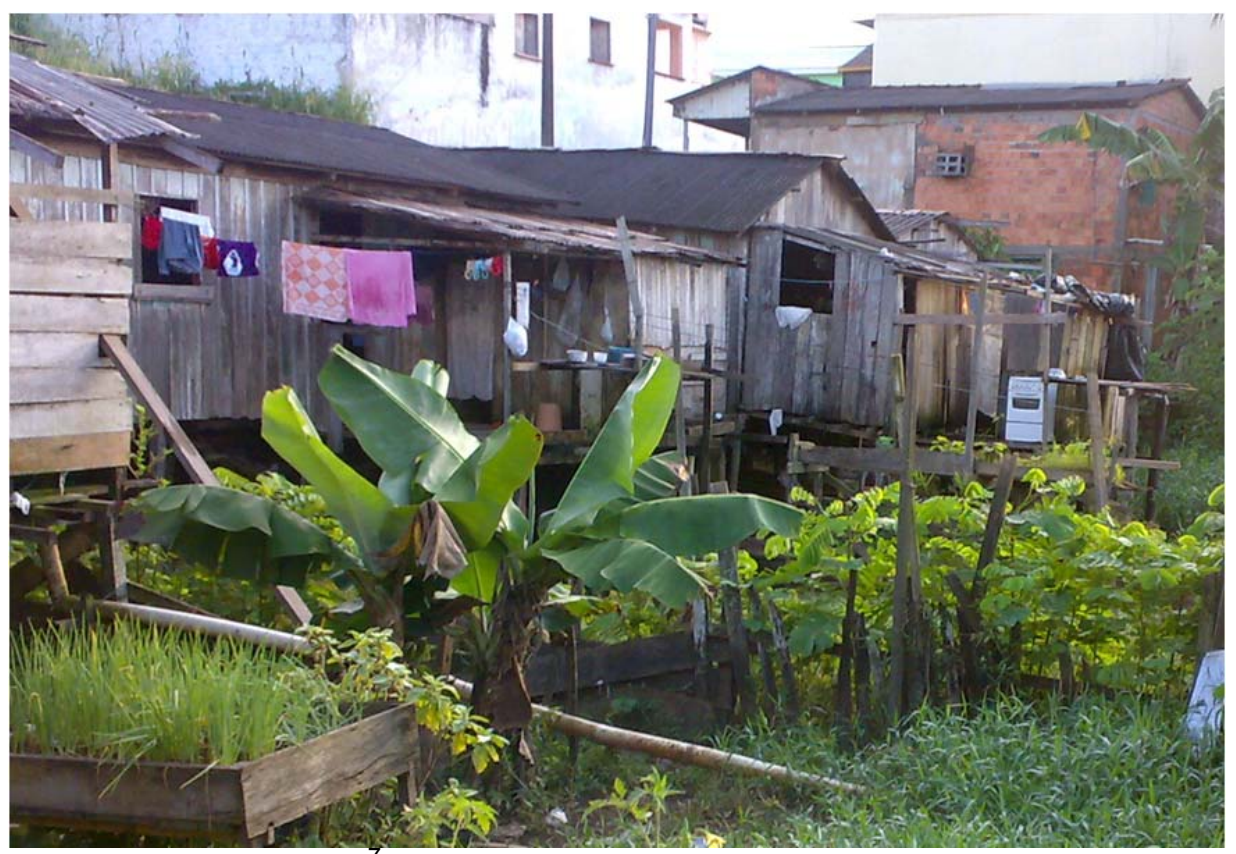

Fonte: Korte e Camargo $2009^{7}$.

\footnotetext{
${ }^{5}$ Korte,R.L.; Camargo,L.M.A. Porto Velho 2008.

${ }^{6}$ Korte,R.L.; Camargo,L.M.A. Porto Velho 2009.

${ }^{7}$ Korte,R.L.; Camargo,L.M.A. Porto Velho 2009.
} 
A pesquisa foi dividida em dois grupos distintos para a pesquisa em seres humanos, o primeiro abrangendo os moradores das áreas ribeirinhas e a pesquisa de vetores, e o segundo com os escolares noturnos.

Figura 16 - Foto da área do Bairro Triâgulo pesquisa em Porto Velho Rondônia, 2008.

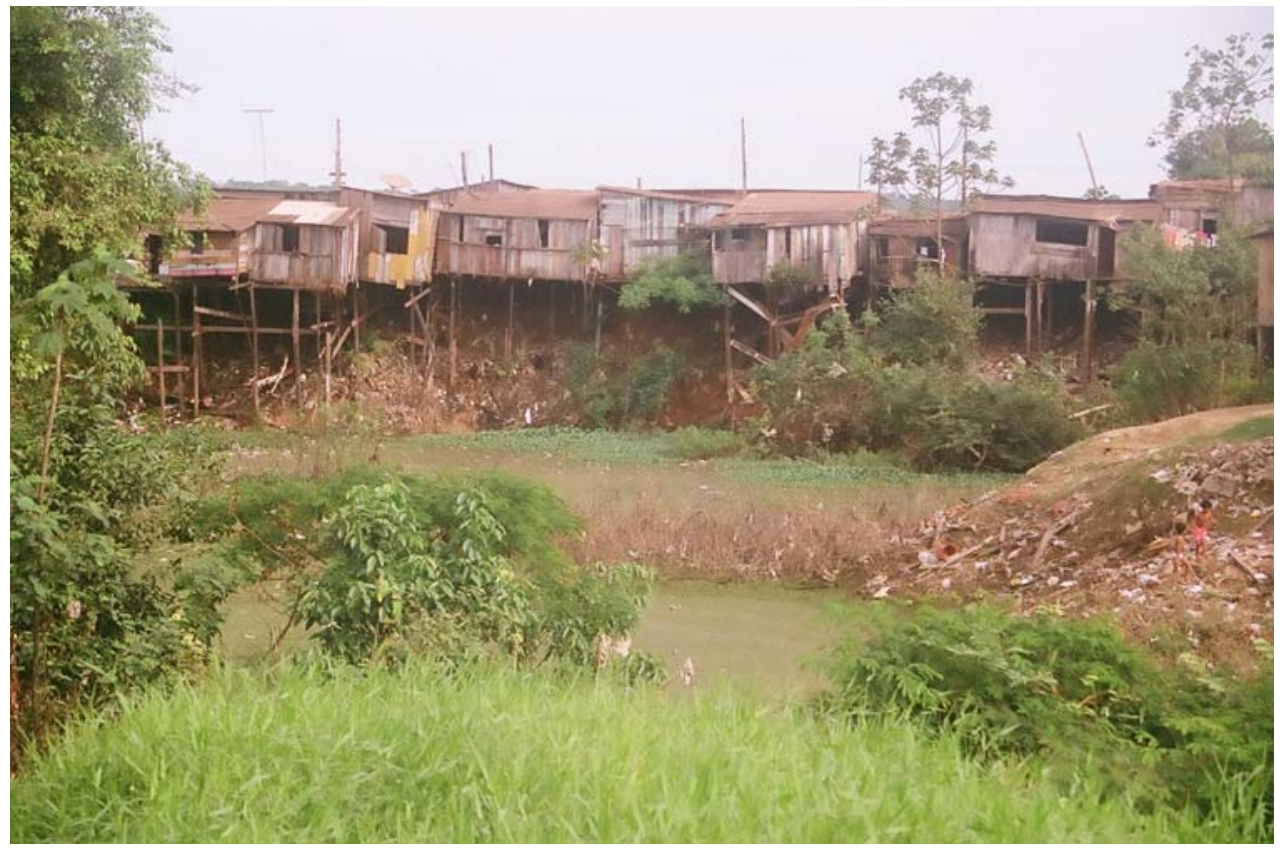

Fonte: Korte e Camargo $2008^{8}$.

\subsection{Grupo 1: População Ribeirinha}

Em Porto Velho, foram escolhidas as áreas em três bairros próximos ao Rio Madeira: Baixa da União, Triângulo e Candelária (Figura 19). Em Guajará Mirim foi escolhido o bairro Triângulo (Figura 28) e em Humaitá a comunidade do bairro Santo Antônio.

A área de pesquisa da população ribeirinha e mais antiga de Porto Velho à beira do Rio Madeira ( $8^{\circ} 45^{\prime} 42.57^{\prime \prime}$ S, $63^{\circ} 54^{\prime} 07.06^{\prime \prime}$ W) foi o alvo deste estudo. A característica da area é a presença de favelas e casas construídas sobre palafitas. A amostra foi randomizada. O tamanho da amostra foi calculado após censo e mapeamento da área de estudo, tendo como cada habitação, uma unidade de

${ }^{8}$ Korte,R.L.; Camargo,L.M.A. Porto Velho 2008. 
amostra; usando uma prevalência empírica de 1\%, um efeito de design de cluster para pesquisas de 1,8, um intervalo de confiança de 95\% calculado pelo OpenEpi 7 .

Neste caso, o tamanho da amostra foi estimado em um total de 557 residências, selecionadas aleatoriamente e 974 indivíduos com mais de cinco anos de idade.

Para a realização da pesquisa, os bairros selecionados foram divididos e demarcados em sete parcelas distintas (figuras 17 a 24), e 1/3 das casas em cada seção foram aleatorizadas e selecionadas. A área estudada corresponde à parcela de residências nas cidades pesquisadas mais antigas e com maior tempo de ocupação. Em média, o tempo de moradia desta população na área era de 10 anos.

Levou-se em consideração para a realização deste estudo, a presença de fluxos migratórios para essa região na década de 1980, em decorrência da exploração do ouro e dos fluxos migratórios para ocupação da Amazônia na década de 1970, e principalmente quando da criação da zona franca de Manaus em 1967.

O estudo em sua fase inicial, foi desenhado como estudo de prevalência na população ribeirinha de Porto Velho.

Figura 17 - Área do estudo contornada por linha branca, Porto Velho, 2008.

Fonte: Google Maps, modificado pelo autor ${ }^{9}$

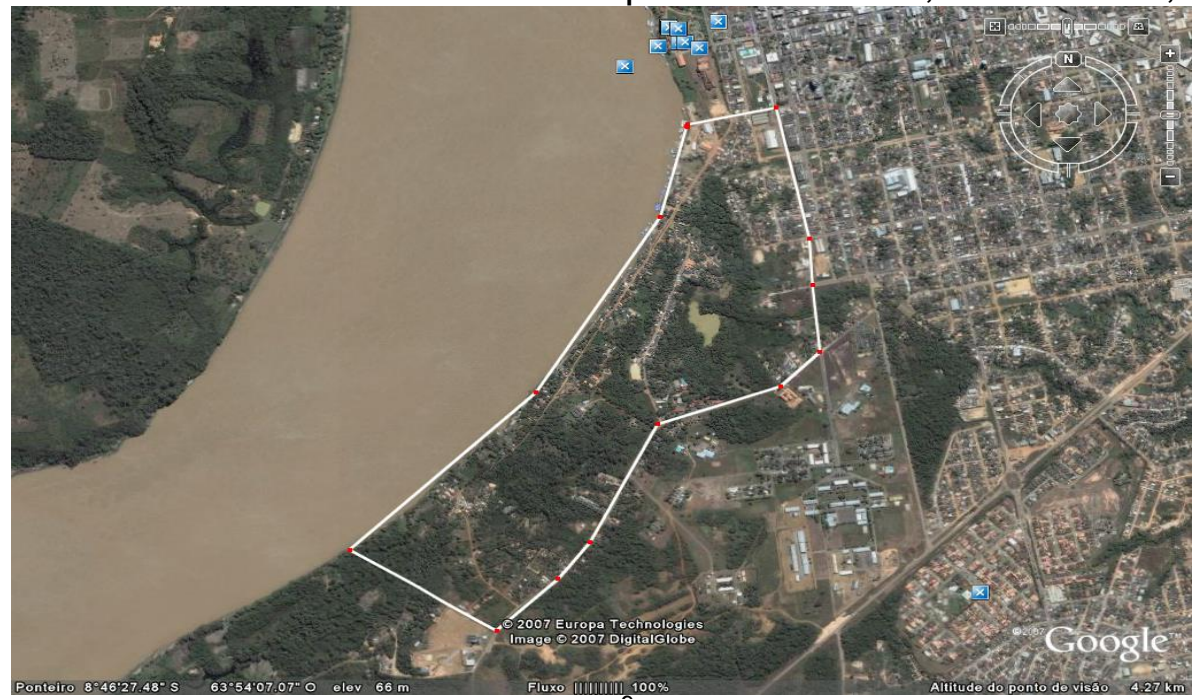

${ }^{9}$ Google Maps. Porto Velho, acesso em 05/02/2008 Modificado por Korte,R.L. 
Figura 18 - Parcela 01 - Bairro Baixa da União, Porto Velho, 2008. Área delimitadas como de maior (Linhas em vermelho) e menor risco (Linha Amarela).

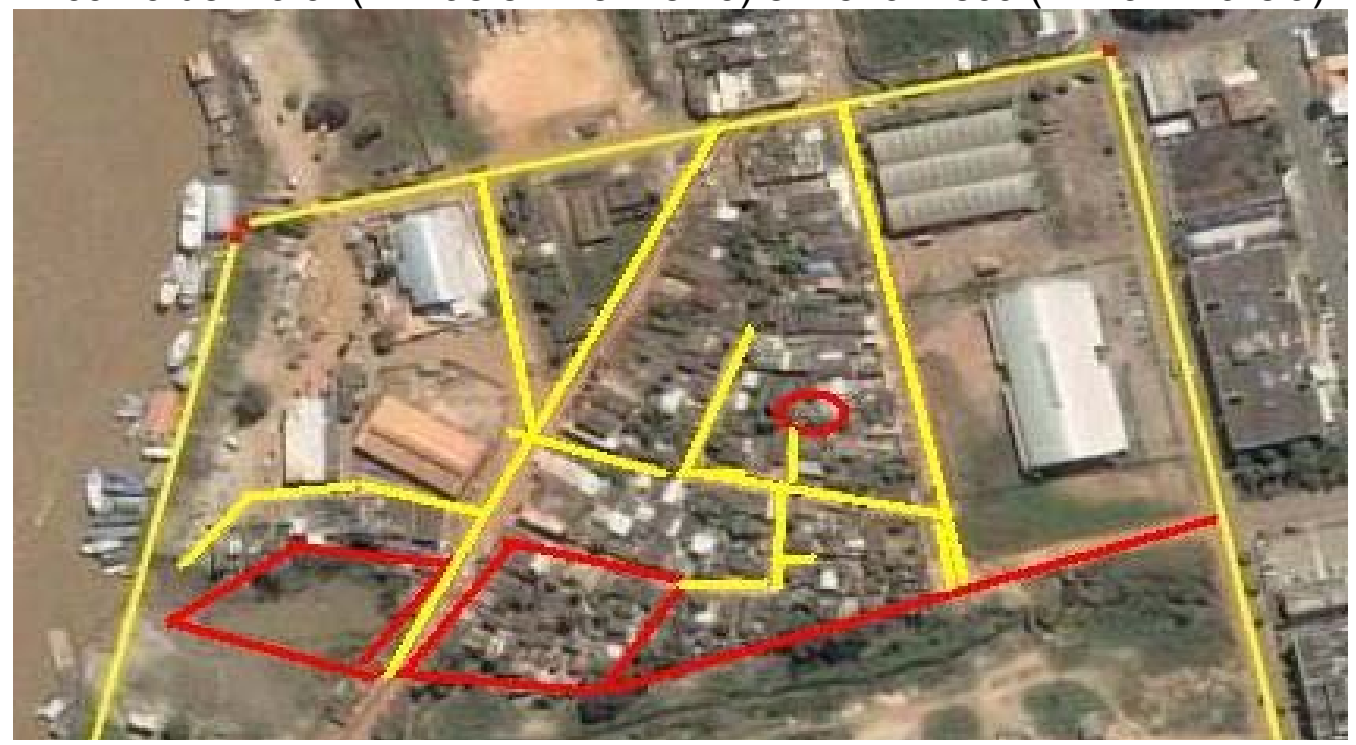

Fonte: Gooale Maps. modificado pelo autor ${ }^{11}$

Figura 19 - Parcela 2- Bairro Baixa da União, Porto Velho 2008. Área delimitadas como de maior (Linhas em vermelho) e menor risco (Linha Amarela).

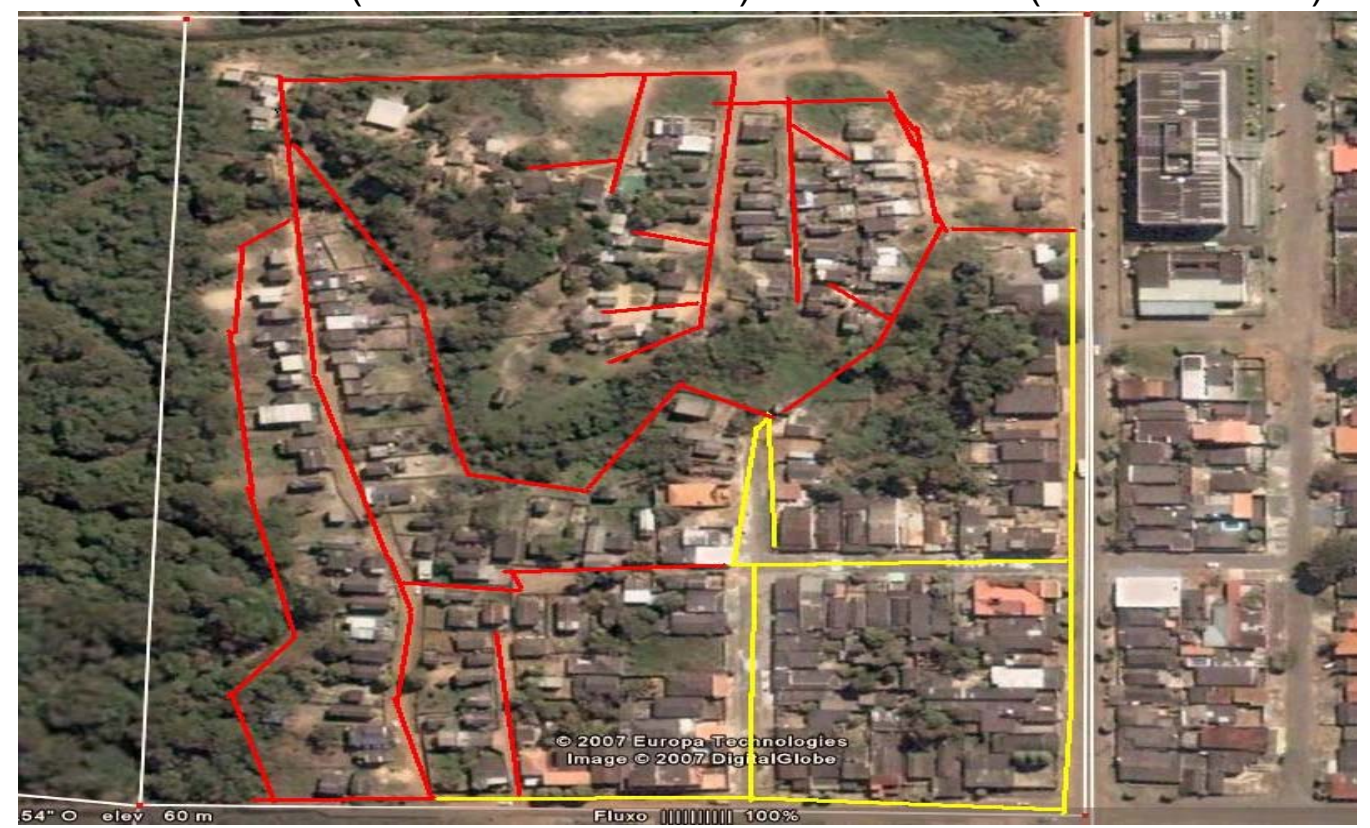

Fonte: Google Maps, modificado pelo autor ${ }^{11}$. 
Figura 20 - Parcela 03 - Bairro Triângulo, Porto Velho, 2008. Área delimitadas como de maior (Linhas em vermelho) e menor risco (Linha Amarela).

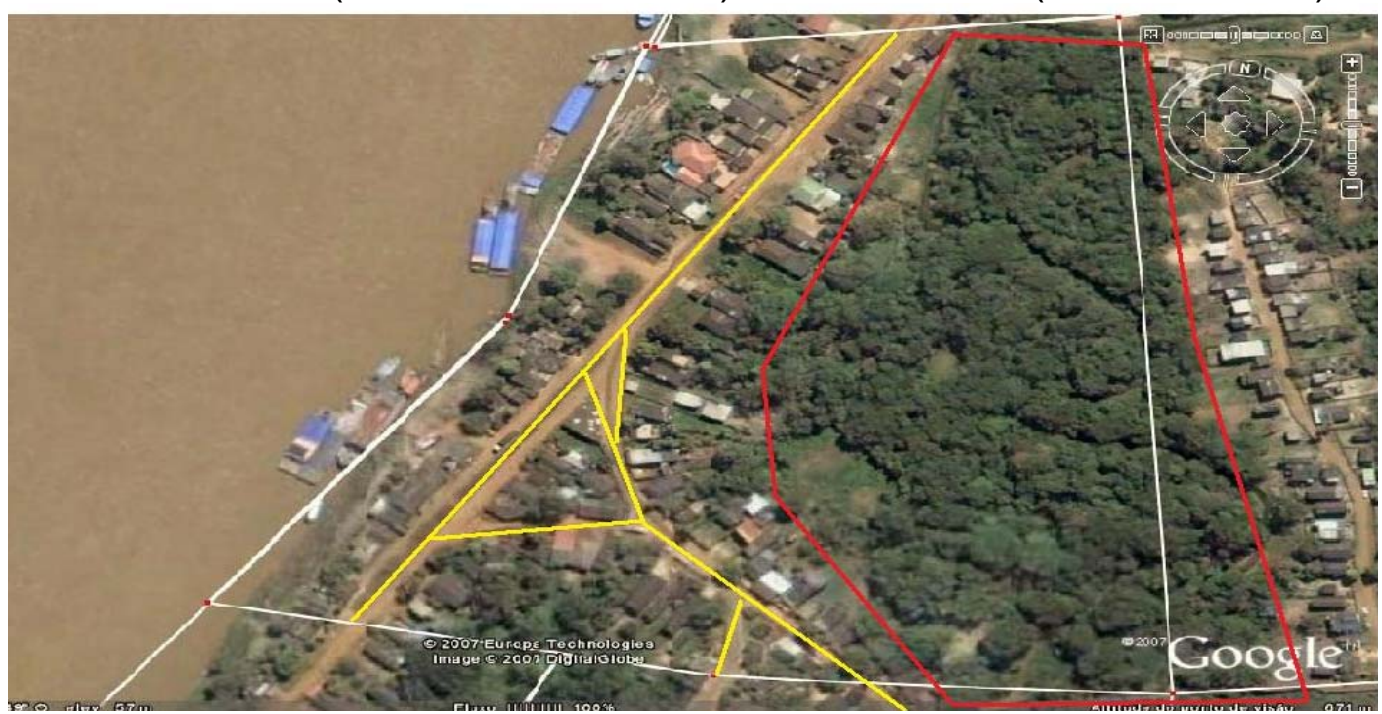

Fonte: Google Maps, modificado pelo autor ${ }^{11}$

Figura 21 - Parcela 04 - Bairro Baixa da União, Porto Velho, 2008. Área delimitadas de menor risco (Linha Amarela).

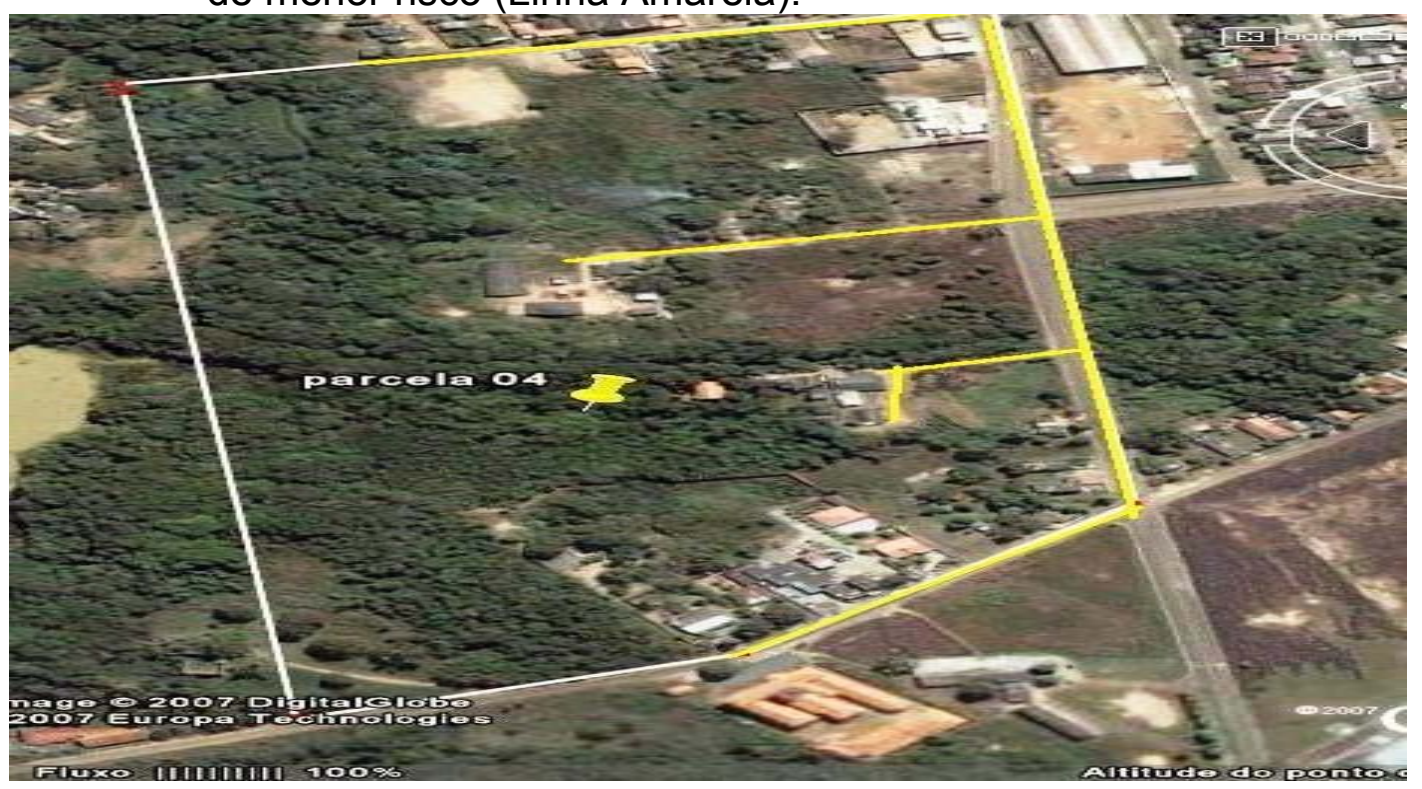

Fonte: Google Maps, modificado pelo autor ${ }^{10}$

${ }^{10}$ Google Maps. Porto Velho, acesso em 05/02/2008 Modificado por Korte,R.L. 
Figura 22 - Parcela 05 - Bairro Baixa da União, Porto Velho, 2008. Área delimitadas como de maior (Linhas em vermelho) e menor risco (Linha Amarela).

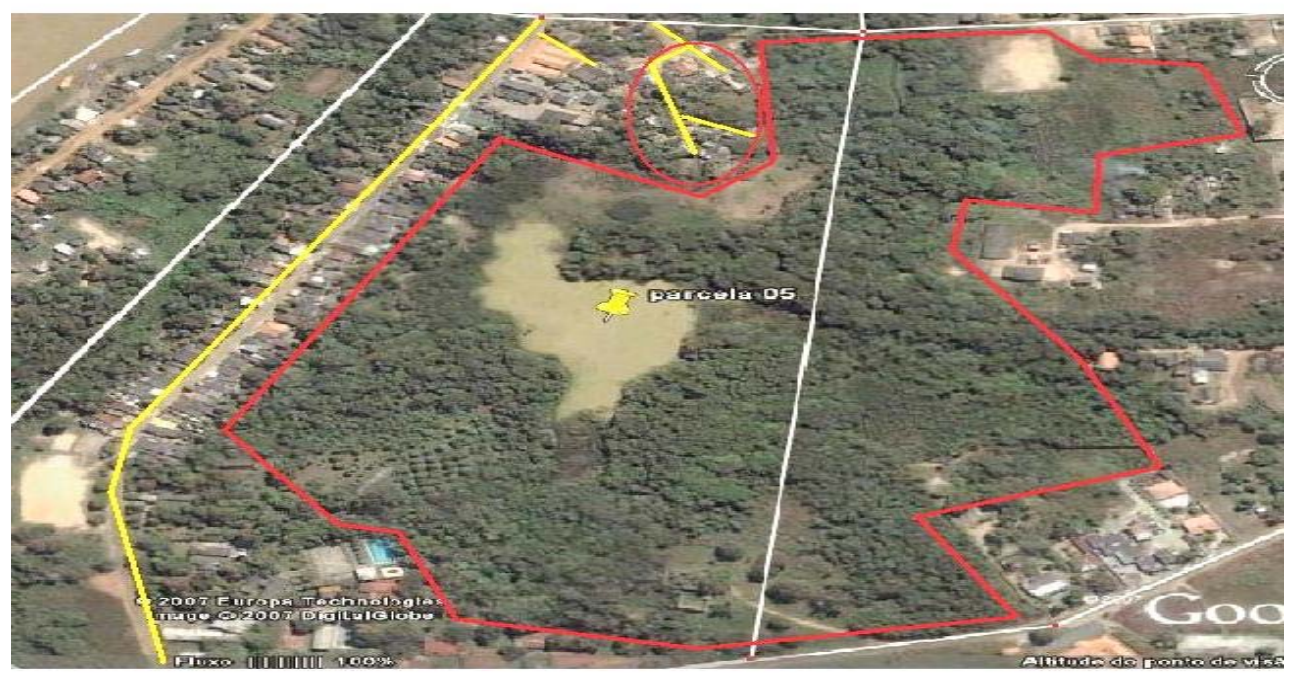

Fonte: Google Maps, modificado pelo autor ${ }^{11}$.

Figura 23 - Parcela 06 - Bairro Candelária, Porto Velho, 2008. Área delimitadas como de menor risco (Linha Amarela).

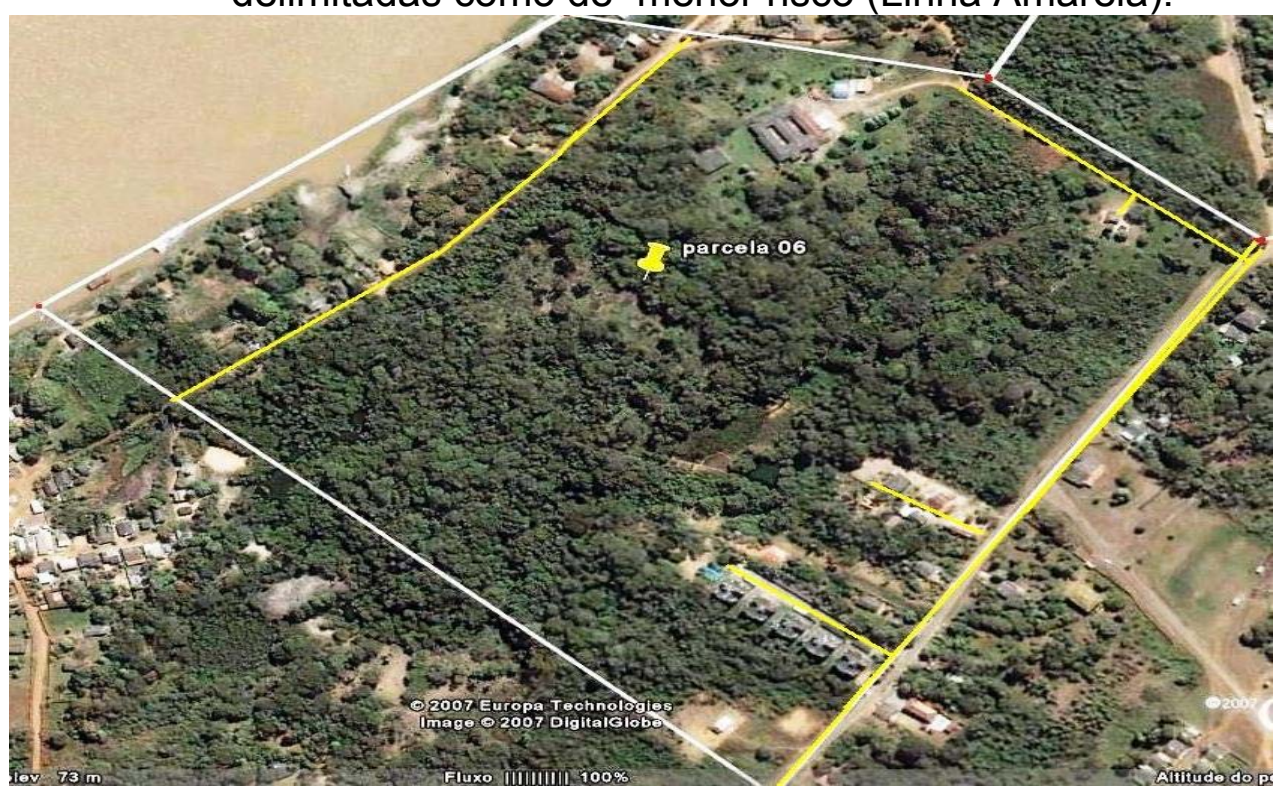

Fonte: Google Maps, modificado pelo autor ${ }^{12}$.

11 Google Maps. Porto Velho, acesso em 05/02/2008 Modificado por Korte,R.L. 
Figura 24 - Parcela 07 - Bairro Candelária, Porto Velho. Área delimitadas como de menor risco (Linha Amarela).

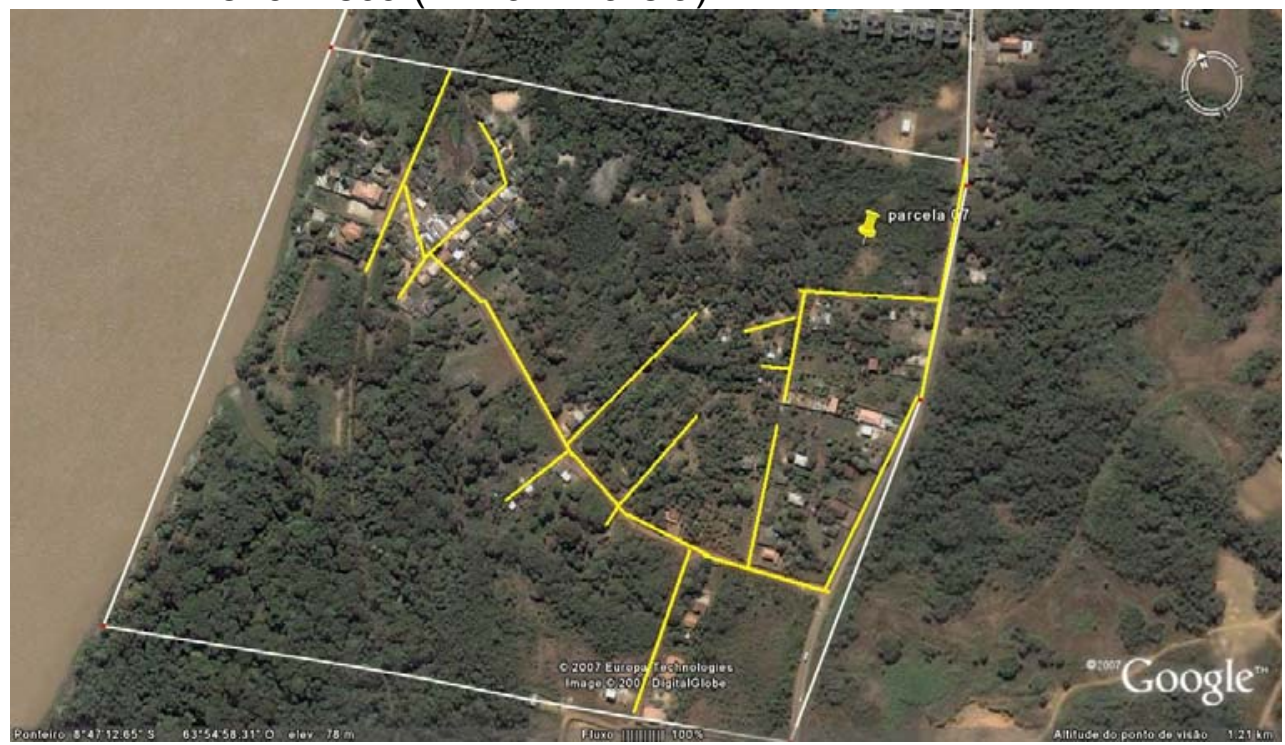

Fonte: Google maps, modificado pelo autor ${ }^{12}$.

\subsubsection{Grupo 2: Escolares noturnos de escolas públicas}

A partir do resultados encontrados na população ribeirinha de Porto Velho, e levando-se em consideração aos estudos realizados na cidade de Maceió, AL, por um de nossos colaboradores, o consultor da Organização Panamericana de Saúde da OMS, o estudo passou a ser uma busca ativa de casos tanto na população ribeirinha de Guajará-Mirim, Humaitá como no grupo de escolares noturnos das cidades peaquisadas.

Foram escolhidas escolas noturnas da rede pública estadual de Porto Velho, Guajará-Mirim e Humaitá, próximas as áreas de risco, dentro dos bairros anteriormente citados. Nas cidades de Porto Velho e Guajará-Mirim a pesquisa foi realizada no período noturno, nas escolas que apresentavam o programa EJA (Escola de Jovens Adultos), do Governo do Estado de Rondônia, o qual atende indivíduos com idade entre 18 e 35 anos, tendo total apoio da Secretaria Estadual de Educação. Na cidade de Humaitá (AM) foi utilizado o mesmo procedimento, com o apoio da Secretaria Estadual de Educação do Estado do Amazonas, com avaliação de escolares do período noturno, sem limite de idade.

${ }^{12}$ Google Maps. Porto Velho, acesso em 05/02/2008 Modificado por Korte,R.L. 
Para as atividades nas escolas, a direção de cada unidade escolar foi sensibilizada acerca da pesquisa, e antes das coletas era realizada um palestra sobre a pesquisa, assim como informações sobre a doença, benefícios do teste, a metodologia da coleta de sangue, dentre outros pontos necessários ao correto entendimento (Figura 31.a e 31.b). Da mesma forma, que ocorreu nas residências, todos os escolares que aceitaram participar da pesquisa assinaram o Termos de Consentimento.

\subsubsection{Determinação da Prevalência Humana de Microfilarêmicos em Visita às residências Porto Velho}

No período da seca, todas as residências foram visitadas pela equipe de trabalho, assim distribuídas: excluindo-se as casas fechadas e/ou as casas onde houve recusa na realização da captura de mosquitos e coleta da gota espessa. As equipes diurnas procediam ao cadastro e marcação das casas para serem visitadas no periodo noturno (Figura 25) (APÊNDICES A e B). Nas residências onde foi realizada a captura de mosquitos, também foram submetidos à coleta de amostras de sangue, obedecendo rigorosamente aos protocolos fixados.

Figura 25 - Foto de casa cadastrada para visita noturna e diurna. Bairro Triângulo, Porto Velho, 2008.

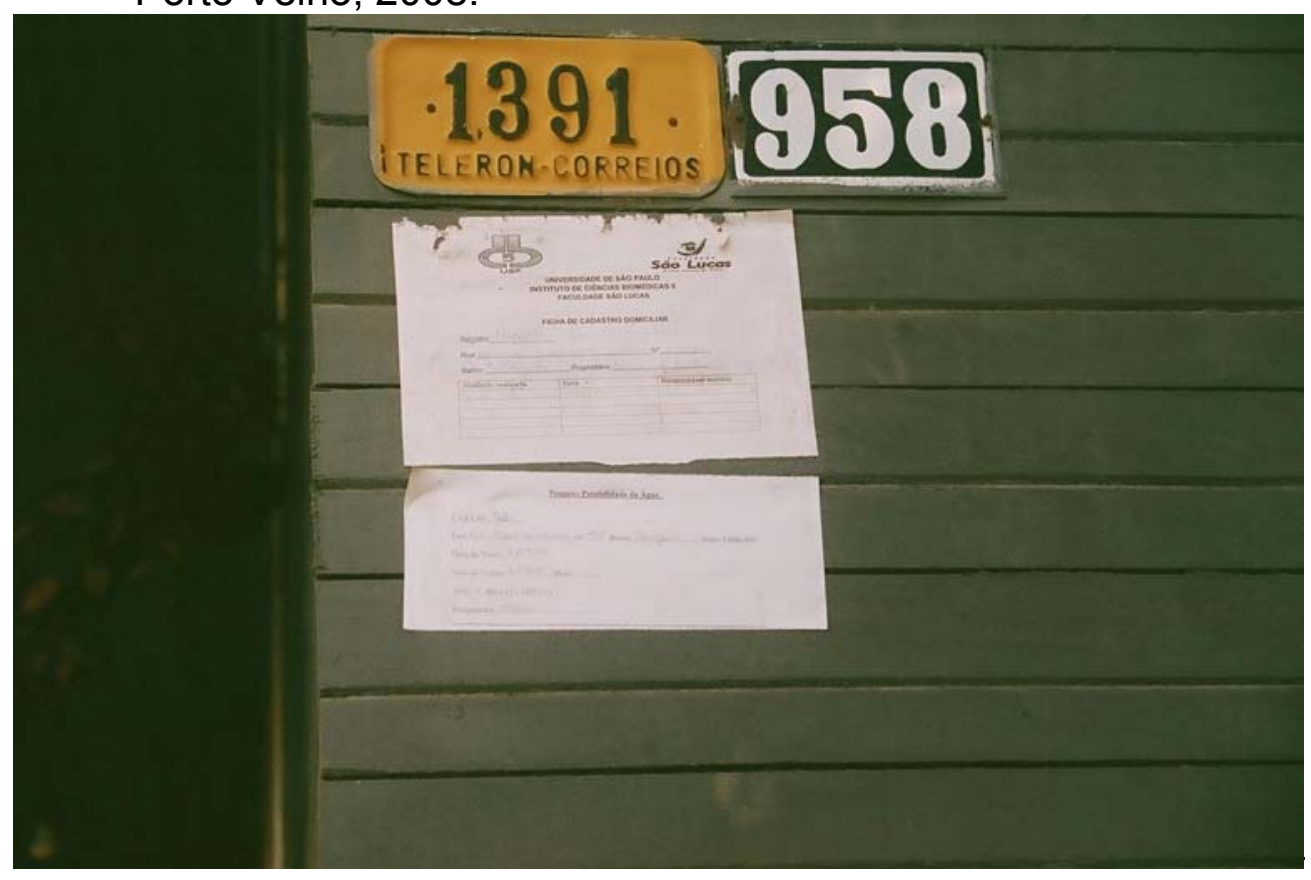

Fonte: Korte e Camargo $2008^{13}$.

13 Korte,R.L.; Camargo,L.M.A. Porto Velho 2008. 


\section{Guajará-Mirim}

Nesta cidade foi escolhido o bairro Triângulo, área antiga da cidade e com os ISA elevados para a ocorrência do vetor. A amostra foi realizada por conveniência. $A$ metodología seguiu aos protocolos já mencionados (Figura 26).

Figura 26 - Foto Bairro Triângulo - Guajará Mirim/RO, 2009 (circundado por linha branca).

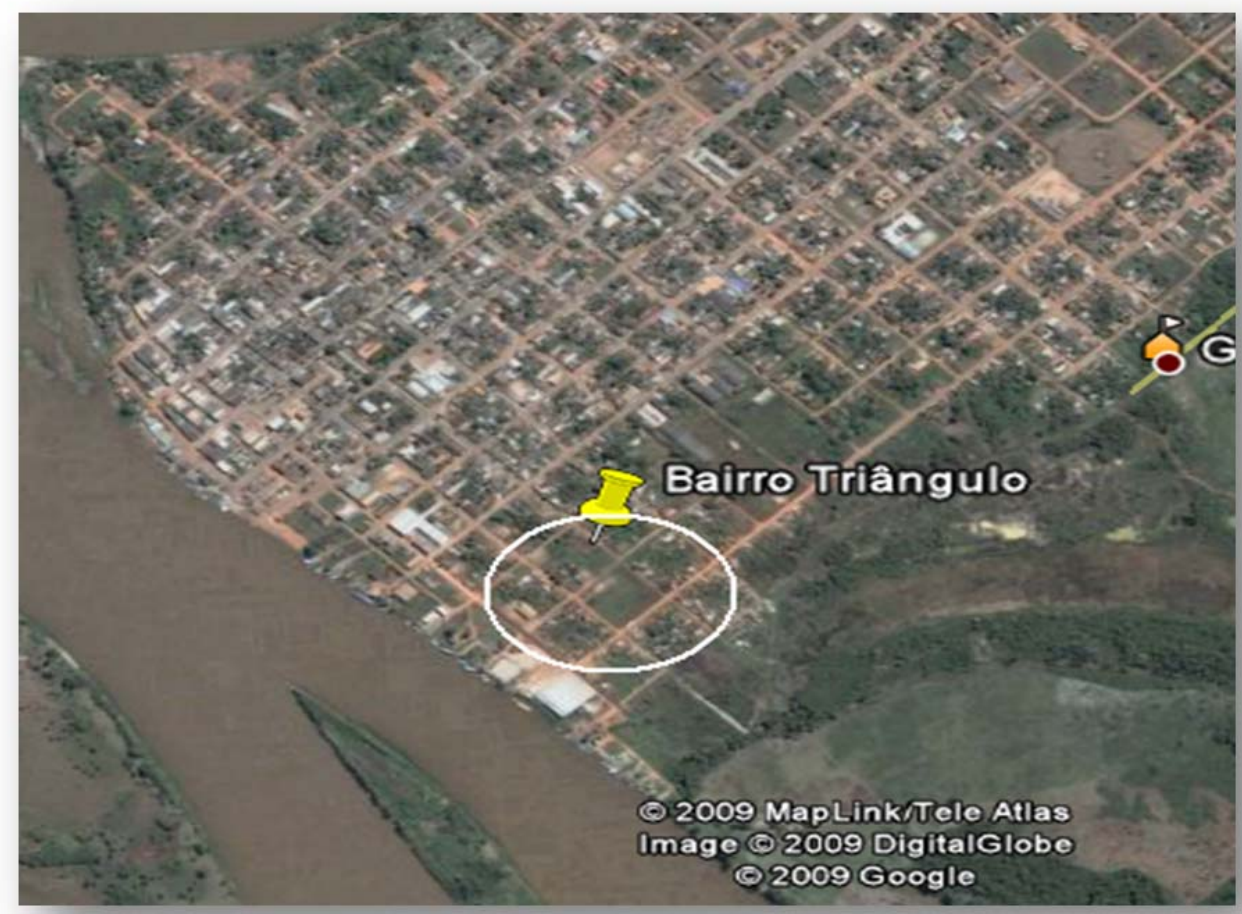

Fonte: Google Maps, modificado pelo autor ${ }^{14}$

\section{Humaitá}

Não contemplada originalmente neste trabalho, a cidade de Humaitá localizada no Estado do Amazonas, a aproximadamente $200 \mathrm{~km}$ da cidade de Porto Velho, apresenta as caracaterísticas necessárias para o desenvolvimento tanto do parasito quanto do vetor.

Foi escolhida a comunidade do Bairro Santo Antônio cuja população é predominantemente ribeirinha. É um dos bairro mais antigos e tem todos os 
indicadores sócio-ambientais predisponentes ao aparecimento da doença. A amostra foi por conveniência, determinadas a partir dos criterios de risco sócio ambientais, asociados às áreas mais antigas de ocupação da cidade.

\subsubsection{Amostras de Sangue}

As amostras de sangue foram colhidas nas residências das áreas demarcadas, entre 22 h e $1 \mathrm{~h}$, devido a periodicidade noturna das microfilárias de $W$. bancrofti no sangue periférico dos parasitados na maioria das regiões endêmicas no mundo (FONTES et al., 2000).

Foi utilizado o método de gota espessa (GE) obedecendo a seguinte técnica: coleta de sangue da polpa digital (utilizando lancetas descartáveis) em lâmina de vidro com ponta fosca, preparando gotas espessas cobrindo um espaço de aproximadamente $2 \times 3 \mathrm{~cm}$ (equivalente a 0,06 a 0,08 $\mathrm{mL}$ de sangue), deixando secar em temperatura ambiente. Doze horas depois de secas, as GE foram desemoglobinizadas, fixadas com metanol, coradas em solução de eosina $(0,05 \%)$, para posteriormente serem coradas com Giemsa. Após a retirada do excesso de corante com água destilada e secas à temperatura ambiente, as lâminas foram examinadas em microscópio óptico na objetiva de 10x e 40x (Figura 27). 
Figura 27- Gota espessa de sangue (A), desemoglobinizada e fixada com metanol $(B)$, e corada (C) para exame ao microscópio óptico.

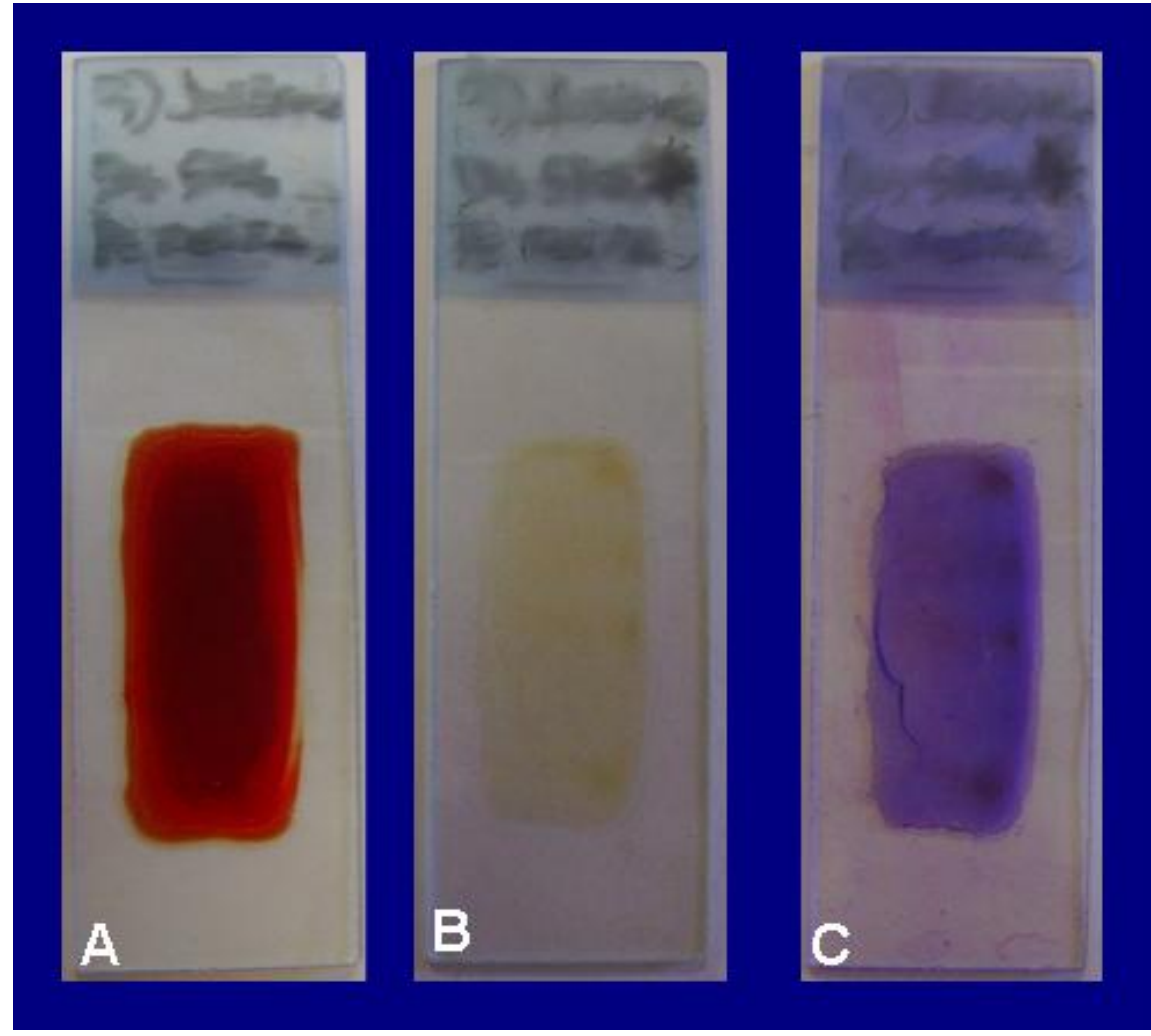

Fonte: Lima, $2008^{15}$.

Após avaliação pelos técnicos do ICB, as lâminas eram devidamente embaladas e conduzidas para a Universidade Federal de Alagoas (UFAL) para conferência.

Os critérios de inclusão obedeceram aos protocolos da OMS. Os testes foram realizados em indivíduos > de 05 anos de idade que aceitaram realizar o exame, com autorização do seu representante (se menor de idade). Foram excluídos os indivíduos < de 05 anos, uma vez que a hipótese considera que o pouco tempo de exposição à infecção não justifica o exame desse grupo (ROCHA et al., 2000).

\subsection{Aspectos Éticos}

Para cada indivíduo examinado foi assinada uma autorização especial, na qual o indivíduo, previamente orientado, firmou o Termo de Consentimento Livre e

\footnotetext{
${ }^{15}$ Lima, A.R.V. Arquivos pessoais. Maceió, AL, 2008
} 
Esclarecido para participar da pesquisa (APÊNDICES C e D). Para os indivíduos menores de idade, foi pedida autorização dos pais ou do responsável. O projeto foi devidamente aprovado pelo CEP da Faculdade São Lucas em 11/12/2007 e pelo CEP do ICB/USP sob número 143/2007.

\subsection{Pesquisa com Vetores em Porto Velho, Guajará-Mirim e Humaitá}

\subsubsection{Coleta dos insetos}

A pesquisa com vetores foi realizada nas mesmas áreas da pesquisa domiciliar em seres humanos.

Foram realizadas capturas de espécimes adultos de mosquitos através da técnica de xenomoritoramento, com o uso de aspirador de sucção e por meio de armadilhas luminosas do tipo CDC. Cada coleta correspondeu a uma residência visitada, sendo que para cada uma utilizavam-se fichas entomológicas (APÊNDICE A) e de cadastramento domiciliar (APÊNDICE B).

As coletas intradomiciliares ocorreram das $7 \mathrm{~h}$ às $10 \mathrm{~h}$ em decorrência da menor atividade do vetor no período pós repasto, e as peridomiciliares entre $22 \mathrm{~h}$ e 7 h, por meio de armadilhas luminosas do tipo CDC, distribuídas em pontos aleatórios.

Somente os mosquitos fêmeas foram armazenados, considerando que somente as fêmeas são hematófagas; os espécimes que não faziam parte da pesquisa (mosquitos fêmeas de espécies não vetores) e outros espécimes, entre eles os machos e os fitófagos, foram descartados, ou seja, não foram encaminhados para a realização da PCR. Os espécimes coletados, após identificação a nível de espécie, foram armazenados em tubos eppendorf (cada tubo com 5 insetos) e congelados a $-20^{\circ} \mathrm{C}$, para posterior exame pela técnica da PCR.

Na sequência, foram encaminhados ao laboratório da Universidade Federal de Alagoas (UFAL) para realização da Reação em Cadeia da Polimerase (PCR), aos cuidados do Prof. Dr. Gilberto Fontes e Prof. Dra. Eliana Maurício da Rocha.

\subsubsection{Reação em Cadeia da Polimerase (PCR)}


A PCR foi feita de acordo com a técnica descrita por Furtado et al. (1997) com modificações no "kit" de extração utilizado para obtenção do DNA. Por essa técnica, o DNA do parasito, se porventura existente nas amostras a serem analisadas, seria extraído e purificado, usando-se o Wizard ${ }^{\circledR}$ Genomic DNA Purification kit (Promega $®)$.

O primer usado para detectar o parasito foi aquele descrito por Zhong et al. (1996), isto é: NV1- 5' GTGATGGCATCAAAGTAGCG 3' e NV2- 5' CCCTCACTTACCATAAGACAAC 3', que amplifica a sequência Sspl com 188 bp. A programação do termociclador (PCR express Themo Hybaid) consistiu em 1 ciclo a $92{ }^{\circ} \mathrm{C}$ por $5 \mathrm{~min}, 30$ ciclos a $92{ }^{\circ} \mathrm{C} / 15 \mathrm{~s}-55^{\circ} \mathrm{C} / 1 \mathrm{~min}-72{ }^{\circ} \mathrm{C} / 1 \mathrm{~min}$ e um ciclo final de extensão a $72{ }^{\circ} \mathrm{C}$ por por $10 \mathrm{~min}$. Em seguida, cada produto de PCR foi aplicado em gel de agarose 1,5\%, impregnado com brometo de etídio, para subsequente eletroforese horizontal à $5 \mathrm{~V} / \mathrm{cm}$ e posterior visualização em luz ultravioleta e documentação fotográfica.

\subsection{Grupo 2 - Alunos do período noturno das escolas públicas Porto Velho}

A segunda fase do trabalho desenvolveu-se em escolas noturnas da rede pública estadual de Porto Velho, Guajará-Mirim e Humaitá. Foram escolhidas as escolas nas regiões mais antigas dessas cidades por localizarem-se próximas às áreas de risco.

Na cidade de Humaitá/AM foi utilizado o mesmo procedimento, com o apoio da Secretaria Estadual de Educação do Estado do Amazonas, com avaliação de escolares do período noturno.

O Programa Escola de Jovens Adultos visa atender indivíduos jovens dos 18 aos 35 anos que não tiveram a oportunidade de iniciar ou concluir o ensino fundamental e médio. Este requisito atendia também a maior faixa etária dos seus alunos, por apresentatem maiores riscos de desenvolver a doença (HOTEZ; SAVIOLI; FENWICK, 2012).

Foram escolhidas 11 escolas localizadas nas áreas mais próximas ao Rio Madeira, compreendidas entre a Avenida Jorge Teixeira ao LESTE, Estrada do Canil ao NORTE, BR 364 ao SUL, e Rio Madeira a OESTE (Figura 29). 
Figura 28 - Mapa da região delimitada como sendo as áreas de maior risco para o desenvolvimento da filariose em Porto Velho, limitadas ao Leste pela Governador Jorge Teixeira, ao sul pela BR-364, ao Oeste pelo Rio Madeira e ao Norte pela Estrada do canil.

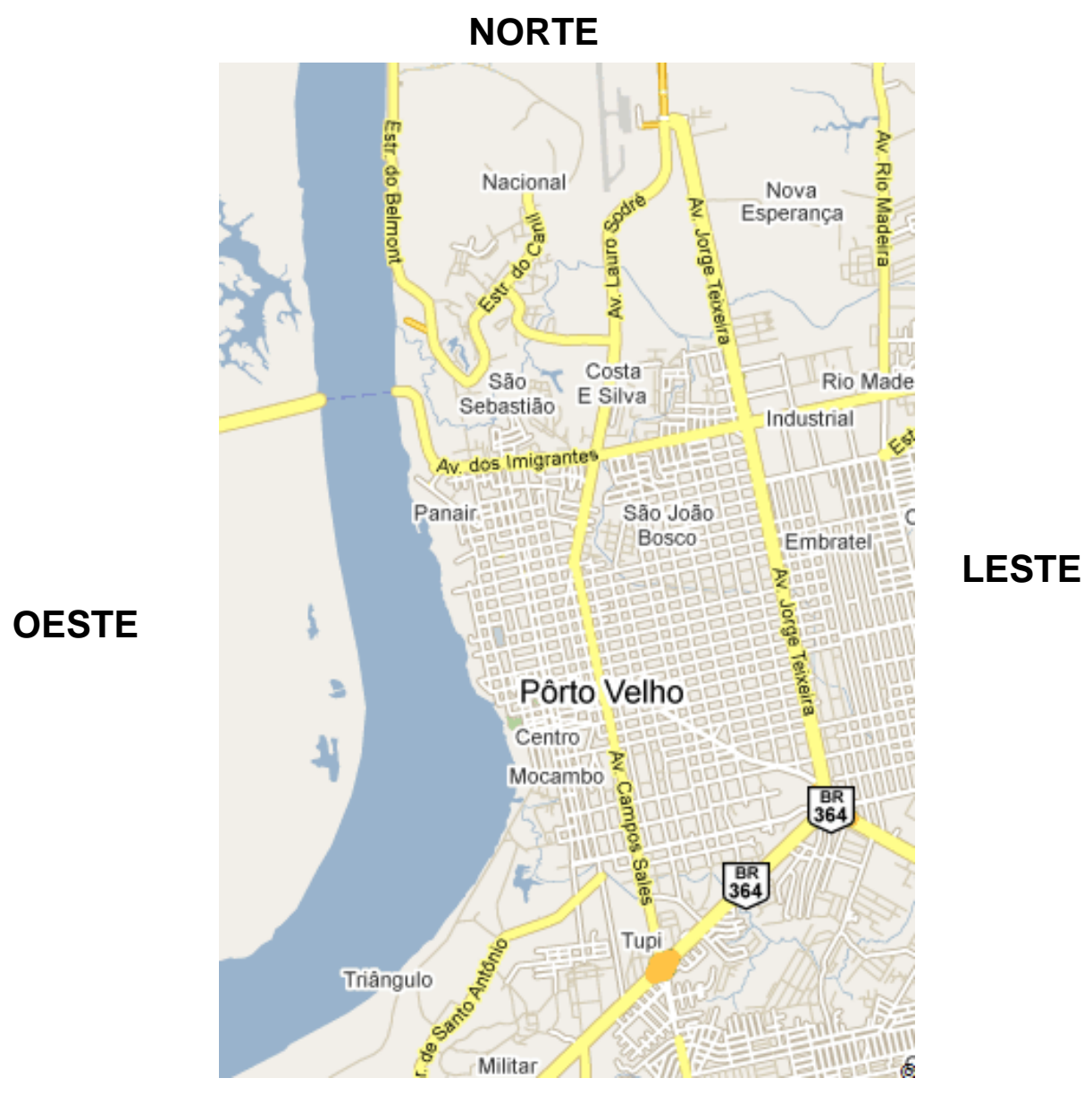

SUL

Fonte: Google maps, 05/02/2009 ${ }^{16}$.

Entre todas as cidades avaliadas estimava-se uma população alvo de aproximadamente 5.800 alunos, segundo dados da Secretaria Estadual de Educação de Rondônia e Amazonas. Contudo, esse número foi reduzido frente aos alunos efetivamente matriculados ser inferior àqueles anteriormente estimados.

Em relação às escolas, a direção de cada unidade escolar era cientificada acerca da pesquisa, no período diurno e, no período noturno $(21 \mathrm{~h} 30 \mathrm{~min})$, a equipe iniciava os trabalhos. Os pesquisadores eram divididos em grupos de 3 que seguiam cada qual para uma das salas de aula. Proferiam palestras sobre o objeto da pesquisa, a doença em si, os benefícios do teste, a metodologia da coleta de

16 Google maps, acessado em 05/02/2009. 
sangue, dentre outros pontos necessários ao correto entendimento (Figura 30.a e 30.b).

Figura 29.a - Palestra ministrada pelos colaboradores antes da coleta da gota Espessa na Escola Estadual Carmela Dutra.

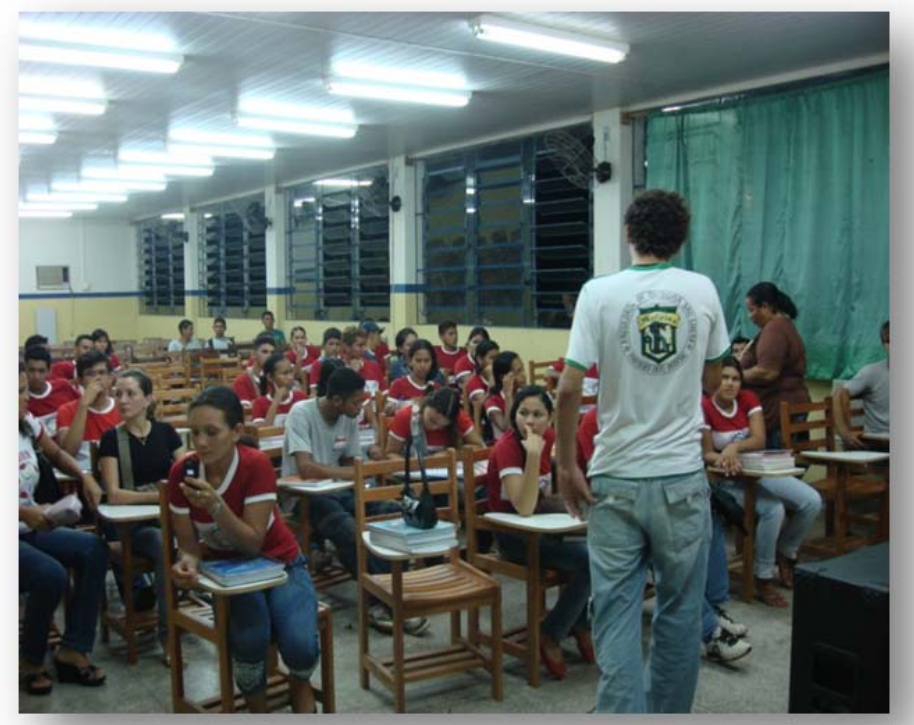

Fonte: Korte e Camargo $2008^{17}$.

Figura 29.b - Palestra ministrada pelos colaboradores antes da coleta da gota Espessa na Escola Estadual Gov. Osvaldo Piana, maio de 2009.

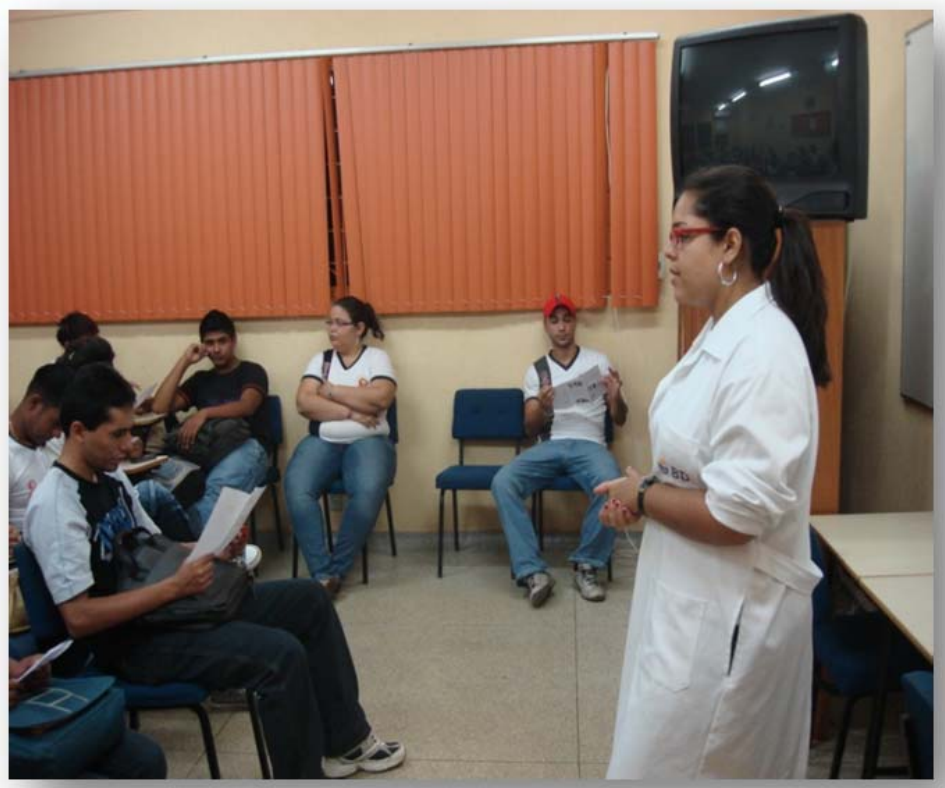

Fonte: Korte e Camargo $2008^{18}$.

17 Korte, R.L., Camargo, L.M.A. arquivos pessoais, Porto Velho 2009. 
Após as palestras abriu-se espaço para o esclarecimento de dúvidas. As questões levantadas pelos estudantes eram respondidas e na sequência os Termos de Consentimento eram assinados. Após essas etapas dava-se iníco à coleta de sangue pelo método da gota espessa nos alunos que consentissem em participar do estudo.

A adesão à pesquisa obteve sucesso, na proporção de $100 \%$, ultrapassando as expectativas do trabalho, inclusive com a coleta de sangue de professores, funcionários, e até familiares dos alunos, os quais gentilmente se ofereciam para que o sangue fosse coletado.

Os indivíduos que já tivessem realizado o exame da gota espessa no inquérito domiciliar eram descartados da pesquisa neste grupo.

Não houve mudanças em relação à metodologia do preparo das lâminas e/ou coleta do sangue, que seguiram rigorosamente os protocolos. Essa etapa foi realizada no período de janeiro a junho de 2009.

\subsubsection{Grupo 2 - Alunos das escolas públicas noturnas de Guajará-Mirim e Humaitá}

$\mathrm{Na}$ pesquisa do grupo 2 do projeto, foram avaliadas os alunos do ensino público noturno, das escolas localizadas nas áreas mais próximas à região da pesquisa domiciliar das cidades de Guajará-Mirim (Figura 31) e Humaitá

Em Humaitá (AM), a pesquisa em escolares noturnos foi realizada em todas as escolas públicas, no período noturno. A adesão à pesquisa também contou com $100 \%$ dos alunos.

18 Korte, R.L., Camargo, L.M.A. arquivos pessoais, Porto Velho 2009 
Figura 30 - Área de abrangência do estudo em escolares noturnos das escolas públicas de Guajará Mirim, 2009.

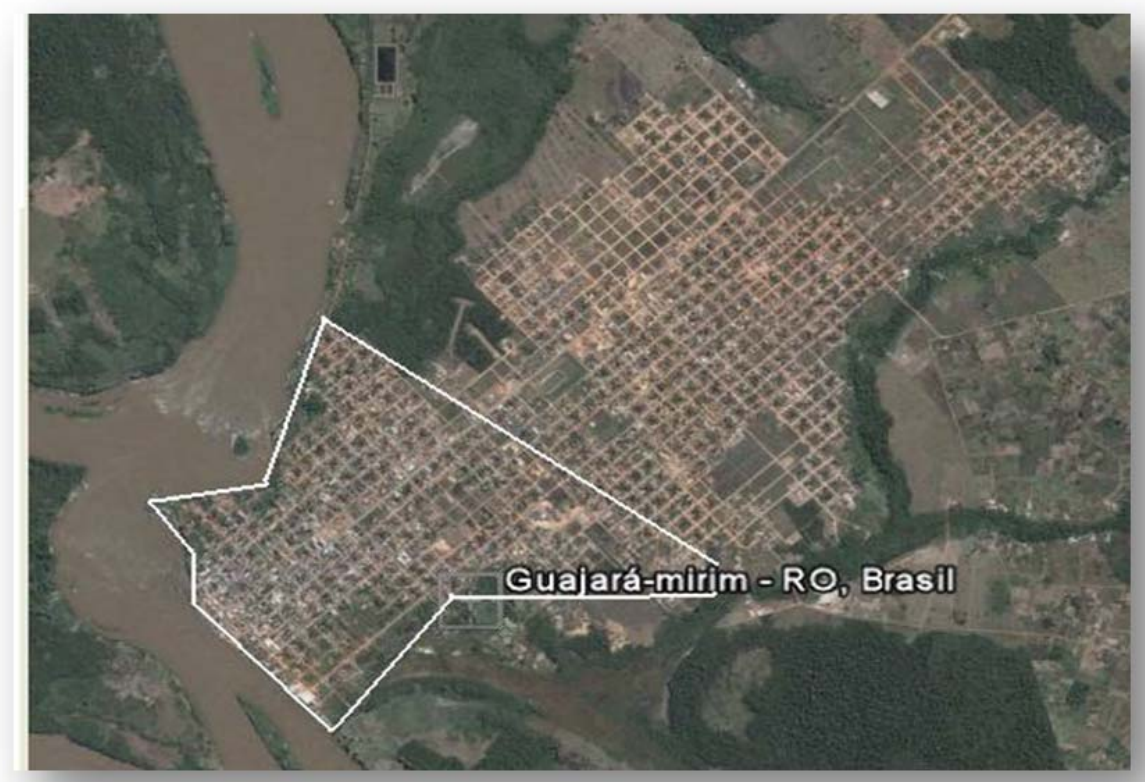

Fonte: Google Maps 17/02/2009 ${ }^{19}$

${ }^{19}$ Google maps, acessado em17/02/2009. Porto Velho. 


\section{RESULTADOS}

\subsection{Resultados da Pesquisa com Vetores}

\section{Porto Velho}

As áreas onde ocorreram capturas de culicídeos foram Porto Velho, nos bairros Cai N’Água, Candelária e Baixa da União. O número total de residências pesquisadas foi de 1.525. O número de residências com o mosquito vetor foi de 1.080 (85,6\%). Foram capturados 3.650 mosquitos, sendo $3.512(96,1 \%)$ do gênero Culex, e 138 (3,9\%) de outros gêneros.

Todos negativos para a pesquisa com PCR (Tabela 1).

\section{Guajará Mirim}

De um total de 275 casas, foram visitadas 261 (95\%). O mosquito vetor foi encontrado em 228 casas (85,6\%). Foram coletados 1.979 mosquitos fêmeas, sendo $1.765(87,9 \%)$ do gênero Culex e $214(12,1 \%)$ de outros gêneros.

Os resultados foram todos negativos para a pesquisa com o PCR (Tabela 1).

\section{Humaitá}

De um total de 324 residências, foram visitadas 164 residências $(50,1 \%)$. O mosquito vetor foi encontrado em 156 residências (84,3\%). Foram capturados 2.583 mosquitos, sendo do mosquito Culex quinquefasciatus $2.572(99,6 \%)$ e $11(0,4 \%)$ de outros gêneros.

Todos os resultados foram negativos para a pesquisa com o PCR (Tabela 1). 
Tabela 1 - Resultados da coleta domiciliar de vetores e da PCR em mosquitos capturados em Porto Velho, Guajará-Mirim e Humaitá, $2008 / 2009$.

\begin{tabular}{|c|c|c|c|c|c|c|c|}
\hline Local & $\begin{array}{c}\text { Total de } \\
\text { Casas } \\
\text { Amostra } \\
\mathbf{N}^{\mathbf{0}}\end{array}$ & $\begin{array}{c}\text { Casas } \\
\text { Visitadas } \\
\begin{array}{c}\mathbf{N}^{\circ} \\
\%\end{array}\end{array}$ & $\begin{array}{c}\text { Casas cl } \\
\text { mosquito } \\
\text { vetor } \\
\mathrm{N}^{\circ} \\
\%\end{array}$ & $\begin{array}{c}\text { Total de } \\
\text { mosquitos } \\
\text { fêmeas } \\
N^{\circ}\end{array}$ & $\begin{array}{c}\text { Mosquito } \\
\text { Culex } \\
\mathrm{N}^{\circ} \\
\% \\
\end{array}$ & $\begin{array}{c}\text { Outros } \\
\text { mosquitos } \\
\text { No }^{\circ} \\
\%\end{array}$ & $\begin{array}{c}\text { Testes de } \\
\text { PCR } \\
\text { positivos } \\
N^{\circ}\end{array}$ \\
\hline P.Velho & 1.525 & $\begin{array}{l}1.262 \\
(82,7)\end{array}$ & $\begin{array}{l}1.080 \\
(85,6)\end{array}$ & 3.650 & $\begin{array}{l}3.512 \\
(96,1)\end{array}$ & $\begin{array}{c}138 \\
(3,9)\end{array}$ & 0 \\
\hline G.Mirim & 275 & $\begin{array}{c}261 \\
(95,0)\end{array}$ & $\begin{array}{c}228 \\
(87,3)\end{array}$ & 1.979 & $\begin{array}{l}1.765 \\
(87,9)\end{array}$ & $\begin{array}{c}214 \\
(12,1)\end{array}$ & 0 \\
\hline Humaitá & 324 & $\begin{array}{c}164 \\
(50,1)\end{array}$ & $\begin{array}{c}156 \\
(84,3)\end{array}$ & 2.583 & $\begin{array}{l}2.572 \\
(99,6)\end{array}$ & $\begin{array}{c}11 \\
(0,4)\end{array}$ & 0 \\
\hline Total & 2.124 & $\begin{array}{l}1.687 \\
(79,4)\end{array}$ & $\begin{array}{l}1.464 \\
(86,8)\end{array}$ & 8.212 & $\begin{array}{l}7.849 \\
(95,6)\end{array}$ & $\begin{array}{l}363 \\
(4,4)\end{array}$ & 0 \\
\hline
\end{tabular}

Figura 31 - Detecção de DNA de $W$. bancrofti no vetor.

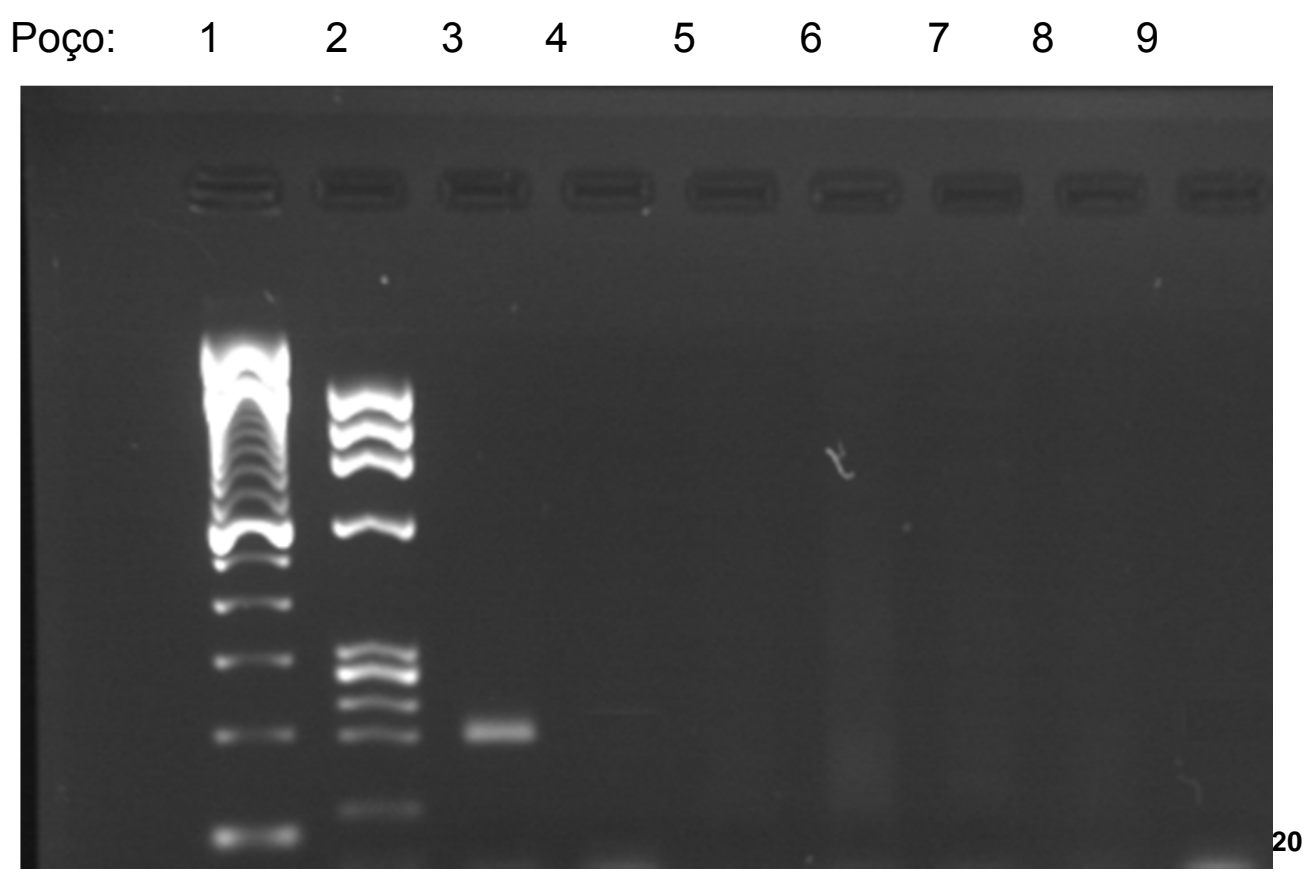

O produto amplificado de $188 \mathrm{pb}$ foi obtido através da eletroforese em gel de agarose a 1,5\% e visualizado pela coloração com brometo de etídio. Poço 1 - Padrão de peso molecular $\phi X$ 174 / HAE III. Poço 2 - Padrão de peso molecular 100pb. Poço 3 - Controle positivo (DNA extraído de mosquito experimentalmente infectado com microfilárias de $W$. bancrofti isoladas de sangue de um paciente). Poço 4 - Controle negativo (mosquitos não infectados). Poços 5-9 - DNA extraído de mosquitos capturados em Porto Velho (RO), Guajará Mirim (RO) e Humaitá (AM)

Fonte: Fontes e Rocha, 2009.

${ }^{20}$ Fontes, G. Rocha, E.M.M., Maceió, AL, 2009. 


\subsection{Resultados da Pesquisa em Seres Humanos}

\subsubsection{Inquéritos domiciliares em Porto Velho, Guajará-Mirim e Humaitá Porto Velho}

$\mathrm{Na}$ pesquisa domiciliar de Porto Velho foram visitados 493 (88,5\%) domicílios de um total de 557. Aceitaram participar, maiores do que 5 anos e/ou estavam presentes, da pesquisa $641(65,8 \%)$ pessoas do total de moradores da área estudada. Todos os moradores apresentaram resultados negativos para filariose pela técnica da gota espessa (Tabela 2).

\section{Guajará-Mirim}

Em Guajará-Mirim, 169 domicílios foram avaliados, sendo que 214 moradores $(42,3 \%)$ de um total de 506 aceitaram participar, maiores do que 5 anos e/ou estavam presentes, da pesquisa. Todos os moradores apresentaram resultados negativos para filariose pela técnica da gota espessa (Tabela 2).

\section{Humaitá}

Em Humaitá foram visitadas todas as casas do antigo bairro Comunidade Santo Antonio. Aceitaram participar, maiores do que 5 anos e/ou estavam presentes, da pesquisa $80(33,3 \%)$ moradores, de um total de 240. Todos apresentaram resultados negativos para filariose pela técnica da gota espessa (Tabela 2).

Tabela 2 - Número de moradores avaliados por região e resultados dos examinados pela técnica de gota espessa de sangue (GE) em inquéritos domiciliares realizados em 2008/2009.

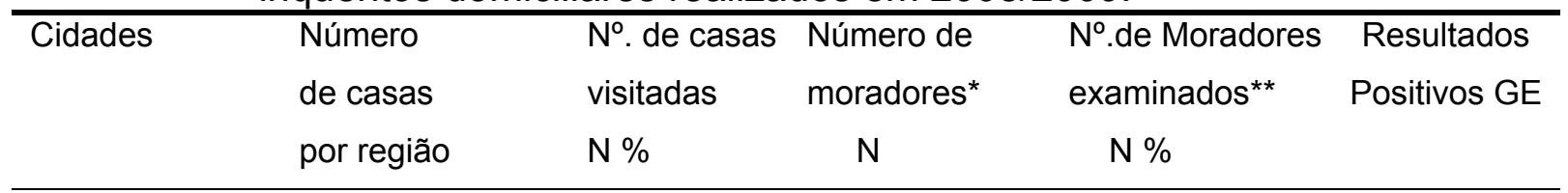




\begin{tabular}{lccccc}
\hline \multicolumn{7}{c}{ avaliada } & & & \\
\hline Porto Velho & 557 & $493(88,5)$ & 974 & $641(65,8)$ & 0 \\
G.Mirim & 169 & $169(100)$ & 506 & $214(42,3)$ & 0 \\
Humaitá & 80 & $80(100)$ & 240 & $80(33,3)$ & 0 \\
\hline Total & 806 & $742(92,0)$ & 1.720 & $935(54,4)$ & 0 \\
\hline
\end{tabular}

*independente da idade, incluindo menores de 5 anos

** moradores que aceitaram participar, elou estavam presente, da pesquisa e com mais de 5 anos de idade

\subsubsection{Resultados da Pesquisa com escolares noturnos}

\section{Porto Velho}

Em Porto Velho, as visitas foram realizadas em 11 escolas noturnas, totalizando 1.684 pessoas $(71,1 \%)$ da população estudantil. Os números inicialmente apresentados pela Secretaria de Educação eram maiores do que o dos alunos que efetivamente frequentavam as aulas. Os dados referentes à pesquisa são em relação ao número total de alunos que frequentavam as aulas do Programa EJA, programa de Educação de Jovens e Adultos, somatória que abrange indivíduos a partir dos 18 anos. Todos apresentaram resultados negativos para a pesquisa de microfilárias de W. bancrofti (Tabela 3).

\section{Guajará-Mirim}

Em Guajará-Mirim foram estudadas 5 escolas. Foram examinados 272 alunos $(81,2 \%)$, cujos resultados foram todos negativos para a pesquisa de microfilárias no sangue (Tabela 3).

\section{Humaitá}

Em Humaitá foram realizadas pesquisas em 7 escolas, examinados 753 alunos $(83,6 \%)$ matriculados no período noturno. Todos apresentaram resultados negativos para a pesquisa de microfilárias de $W$. bancrofti (Tabela 3).

Tabela 3 - Resultados da pesquisa de amostras de sangue pela técnica da gota espessa em escolares noturnos de Porto Velho, Guajará-Mirim, Humaitá, 2009.

\begin{tabular}{ccccc}
\hline Locais & $\begin{array}{c}N^{\circ} \text { de escolas } \\
\text { Examinadas }\end{array}$ & $\begin{array}{c}\mathbf{N}^{\circ} \text { Total de } \\
\text { escolares }\end{array}$ & $\begin{array}{c}\text { Escolares } \\
\text { examinados }\end{array}$ & $\begin{array}{c}\text { Resultados } \\
\text { positivos }\end{array}$ \\
\hline
\end{tabular}




\begin{tabular}{ccccc}
\hline & & $\mathbf{N}^{\mathbf{0}} \%$ & $\begin{array}{c}\text { gota espessa } \\
\mathbf{N}^{\mathbf{0}}\end{array}$ \\
\hline $\begin{array}{c}\text { Escolas Noturnas } \\
\text { P.Velho }\end{array}$ & 11 & 2.368 & $1.684(71,1)$ & 0 \\
$\begin{array}{c}\text { Escolas Noturnas } \\
\text { G.Mirim }\end{array}$ & 5 & 333 & $272(81,2)$ & 0 \\
$\begin{array}{c}\text { Escolas Noturnas } \\
\text { Humaitá }\end{array}$ & 7 & 900 & $753(83,6)$ & 0 \\
\hline Total & 23 & 3.601 & $2.709(75,2)$ & 0 \\
\hline
\end{tabular}

\section{DISCUSSÃO}

Na década de 1950 foram encontrados casos de filariose linfática na região de Porto Velho e Guajará-Mirim (Rachou, 1953), mas considerados não-autóctones. $\mathrm{Na}$ ocasião foram tomadas as medidas necessárias para o tratamento dos infectados. No entanto, após os estudos realizados por Rachou na década de 1950, nada mais foi feito em relação à prevenção da doença, ou mesmo qualquer estudo acerca da sua ocorrência naquelas cidades. Enquanto isso, a cidade de Maceió, considerada pelo MS como área de não ocorrência de filariose linfática em 1985, apresentava a doença em caráter endêmico nos estudos de Dreyer et al. e Fontes et al. nos anos 1990 (DREYER et al., 1991; FONTES et al., 1998).

$\mathrm{O}$ mesmo poderia estar ocorrendo em Porto Velho e adjacências quanto à presença do vetor e indivídos microfilarêmicos, tal como ocorreu em Maceió, Manaus, Belém e Recife. Essa conclusão deve-se ao fato das cidades de Porto Velho, Guajará-Mirim e Humaitá possuírem condições semelhantes àquelas cidades, como clima, temperatura, infraestrutura precária, ausência de saneamento básico, baixas condições socioeconômicas e presença de $C$. quinquefasciatus.

A intensidade e o potencial de estabelecimento de focos da filariose linfática depende exclusivamente (a) da quantidade de portadores de $W$. bancrofti; (b) da densidade de microfilárias nestes indivíduos; (c) da presença do mosquito vetor em potencial; (d) características individuais da população de vetores, e das condições socioambientais adequadas para disseminação tanto do vetor quanto do parasito.

Atualmente, o único foco da doença no Brasil concentra-se nas cidades de Recife, Olinda, Paulista e Jaboatão dos Guararapes (FONTES et al., 2012) 
sobretudo em áreas de favelas, e onde não há água tratada, esgotamento sanitário, coleta de lixo, o que diretamente associa-se às populações de baixa renda e baixo nível de escolaridade.

Barbosa et al. (2007), demonstrou que $73 \%$ dos indivíduos parasitados em Recife estavam localizados nas áreas com os indicadores de risco sócio-ambientais elevados para o desenvolvimento tanto do vetor como do parasito (BARBOSA et al., 2007). Esses fatores são determinantes para que se mantenha a filariose endêmica em uma determinada região, semelhante ao encontrado nos bairros de Maceió (FONTES et al., 1998).

Outro fator associado à possibilidade do desenvolvimento da doença em Porto Velho, Guajará-Mirim e Humaitá é a presença do mosquito vetor, $C$. quinquefasciatus, em quantidades alarmantes, como ficou demonstrado nas coletas realizadas. Esse mosquito é o único transmissor da filariose linfática no Brasil.

Assim, este estudo tomou por base atender à população que, de forma inequívoca, está submetida a fatores sócio-ambientais de risco, frente à pobreza, inexistência de saneamento básico e proximidade de sítios de maior proliferação do vetor e os indivíduos mais propensos à doença, que são os jovens com faixas etárias entre 18 e 35 anos, contemplados neste estudo com a realização da pesquisa no programa de escolares noturnos do EJA do Estado de Rondônia ( Estudo par Jovens Adultos) e escolares noturnos da cidade de Humaitá, Estado do Amazonas (Dreyer, 1999; ROCHA, 2000).

Importa salientar que o mosquito $C$. quinquefasciatus é o mais encontrado na região estudada. Os estudos de Simonsen e Mwakitalu (2013) afirmam ser o Culex o principal vetor da filariose bancroftiana no mundo, sendo o único transmissor no Brasil.

Existem fatores relacionados ao vetor que podem impedir ou dificultar a transmissão da filariose, isto é, o mesmo vetor que transmite a doença em determinada região mostra-se inócuo em outra, ou seja, podem variar na mesma espécie em localidades diferentes. Assim, a presença de indivíduos e/ou linhagens de C. quinquefasciatus com baixa competência vetorial, poderiam ser fator de limitação na disseminação do parasito (BRITO et al., 2001; CARVALHO et al., 2008; CHRISTENSEN; SUTHERLAND; GLEASON, 1984).

O mosquito C. quinquefasciatus apresenta hábitos hemofágicos noturnos e, no Brasil, a filariose bancroftiana apresenta periodicidade noturna, com picos entre 
22 h e 1 h (FONTES et al., 2000), que corresponde ao período de hematofagia do vetor, o que demonstra que há uma associação entre a presença de microfilárias na corrente sanguínea durante o período de repasto sanguíneo, permitindo a contaminação do vetor pelo parasito (PAILY; HOTI; DAS, 2009; WHITE, 1989).

A competência vetorial retrata-se na capacidade de desenvolvimento das formas de microfilárias para L1 e para formas larvais infectantes $L 3$, e pela sua capacidade de limitar a carga parasitária quando exposto a altas concentrações do parasito, em áreas onde as taxas de microfilaremias são altas. Essa capacidade de impedir a evolução das formas larvais e limitar a carga filarial aumentam a letalidade vetorial e diminuem a capacidade de transmissão (BRITO et al., 2001; CARVALHO et al., 2008; CHRISTENSEN; SUTHERLAND; GLEASON, 1984). Outro fator existente, é a carga de filárias presentes no vetor, que apesar de aumentarem a probabilidade de disseminação da doença, também pode ser fatal para o vetor quando esta for demasiadamente elevada, aumentando sua letalidade e colaborando para a redução da transmissão (CHANDRA, 2008; SNOW; MICHAEL, 2002).

Outro fator de limitação vetorial foi descrito por Serrão, Labarthe e Lourenço de Oliveira (2001) ao descreverem que a não ocorrência da doença também pode estar ligada ao repasto sanguíneo nos vetores com baixa competência vetorial, na medida em que nem todas as larvas ingeridas pelo mosquito sobrevivem no trato gastrointestinal, sendo que algumas dessas larvas são expelidas pelo próprio vetor e outras são lesadas pelo aparelho bucofaríngeo durante o repasto, diminuindo dessa forma a transmissão.

Isso potencializa-se, especialmente se conjugado ao processo de melanização, que consiste em destruir o parasito por meio da deposição de substância melanótica (CHRISTENSEN; TRACY, 1989), bloqueando completamente os nutrientes necessários à sobrevivência do parasito (CHEN; CHEN, 1995), reduzindo a infecção do vetor.

Chandra (2008) corrobora com os estudos de Serrão, Labarthe e Lourenço de Oliveira (2001) chegando à conclusão de que a rápida coagulação do sangue no intestino do mosquito e a formação de cristais seguia-se a uma redução considerável do movimento das microfilárias, uma vez que impedia a migração das formas larvais ingeridas durante o repasto para o tórax e abdômen do mosquito. 
Brito et al. (1998) verificaram que o índice de infecção de mosquitos que se alimentam em indivíduos que apresentavam baixa microfilaremia por $W$. bancrofti (1$10 \mathrm{mf} / \mathrm{mL}$ ) foi igual a $0,07 \%$, sendo a eficiência do vetor de aproximadamente $17 \%$. Ou seja, para seis microfilárias ingeridas somente uma se desenvolvia até a forma de larva infectante (L3). Concluíram que o índice de infecção de mosquitos é proporcional à densidade de microfilárias no sangue periférico dos pacientes (BRITO et al., 1998).

Em estudos recentes em Maceió, Leite et al. (2010) demonstraram que a carga microfilarêmica de um paciente é um dos fatores determinantes para a manutenção e criação de um foco de transmissão de filariose linfática. Essa carga pode ter sido um dos fatores que obstaculizaram a não disseminação da doença nas áreas estudadas (Porto Velho, Guajará-Mirim e Humaitá).

Leite et al. (2010) verificaram em Maceió que um indivíduo microfilarêmico por $W$. bancrofti - migrante de área endêmica e residente por mais de 10 anos em área não endêmica - foi incapaz de induzir a formação de um novo foco de bancroftose, apesar das áreas possuírem condições ambientais similares. Uma das hipóteses aventadas por esse pesquisador foi a baixa microfilaremia do parasitado, ou seja, 4 microfilárias por $\mathrm{mL}$ de sangue (LEITE et al., 2010).

Confirmando este estudo, Das e Vanamail (2008) observaram que a filariose linfática, abaixo de um determinado número crítico de picadas infectantes, não é sustentada como uma doença endêmica. Constataram que em locais onde a densidade de microfilárias é mantida abaixo de 5 microfilárias / $60 \mu \mathrm{L}$ considera-se que não há risco de transmissão quando associado a baixas densidades de mosquitos (DAS; VANAMAIL, 2008).

Justo supor, sob esse prisma, que as baixas microfilaremias na década de 1950, e o tempo reduzido de exposição dos indivíduos parasitados ao vetor, tenham sido os fatores para a não disseminação da doença nesta região (Porto Velho, Guajará-Mirim e Humaitá).

Seguindo essa linha, a discussão envolve respostas que adentram estudos realizados por Hairston et al. já na década de 1960, os quais demonstraram com eficiência, que somente $41,4 \%$ das larvas infectantes saem do mosquito durante o repasto, e somente $32 \%$ das larvas de $W$. bancrofti conseguem adentrar a corrente sanguínea do ser humano e apenas algumas dessas formas infectantes sobrevivem no homem. As formas imaturas no vetor que não evoluíram, não sobrevivem no seu 
hospedeiro, diminuindo em muito a carga de filárias contaminantes (L3). Isso aumenta sobremaneira, o número de picadas necessárias por mosquitos infectados com o parasito para que ocorra a infecção. Estima-se que sejam necessárias 15.500 picadas infectantes para se estabelecer microfilaremia em 1 pessoa (HAIRSTON et al., 1968).

A correlação entre meio ambiente, vetor e parasita ficou bem demonstrada como sendo um fator limitador na transmissão da filariose, seja pelo vetor, seja pelo parasita.

Em outro estudo realizado por Kasili et al. (2009) ficou demonstrado que as taxas de infecção do mosquito pela microfilária foram de $1,49 \%$ e de $0,21 \%$ quando comparadas à estação das chuvas (inverno) e verão (seca) respectivamente, demonstrando que existe íntima correlação entre o clima e as condições ideais de desenvolvimento e transmissão das microfilárias.

No inverno, Porto Velho, Guajará-Mirim e Humaitá apresentam as características ideiais e necessárias para o desenvolvimento do parasito na forma larval infectante. Entretanto, nos períodos de maior calor e umidade, ocorre uma diminuição dos vetores, inexistindo sincronia entre as larvas infectantes e o número de vetores, reduzindo os riscos de transmissão.

Chandra (2008) advoga ser esse um dos principais fatores limitantes na transmissão da filariose bancroftiana, ante inexistência de sincronização entre a abundância do vetor e das condições ambientais para o desenvolvimento do agente causador da doença (CHANDRA, 2008).

Em um estudo realizado por Farid et al., 2000, em que compara a umidade do ar, temperatura, localização (mais rural e urbana), e vento em duas vilas com taxas de prevalência de microfilaremia de $10,8 \%$ e $2,1 \%$, no delta do Nilo, observaram que a diferença existente da prevalência se dava principalmente pela maior sobrevida dos mosquitos $C$. pipiens numa das vilas quando comparada a outra (FARID et al., 2000).

Todos esses estudos demonstram que a persistência da endemia depende da ocorrência de altas taxas de infecção natural nos mosquitos. No entanto, não existe um consenso entre os pesquisadores que possa prever o surgimento de um novo caso de filariose no ser humano com microfilaremia patente (WITT; OTTESEN, 2001). 
Neste estudo não foram detectados microfilarêmicos por W. bancrofti através da gota espessa de sangue, tampouco mosquitos infectados. Nas diversas áreas avaliadas, a técnica de detecção do parasito no vetor foi a PCR. Igualmente, não foram encontradas evidências de formação de focos, mesmo com a existência de vetores do parasito em condições ambientais semelhantes às de outras cidades em que a doença se disseminou.

Os casos descobertos nas cidades de Porto Velho e Guajará Mirim, por Rachou na década de 1950, foram considerados alóctones e o período de exposição destes indivíduos foi considerado pequeno para a disseminação da doença.

Em estudo sobre a proporção de relatos da Rede de Vigilância GeoSentinell de infecções causadas por filarídeos, 1,6\% ocorreu em imigrantes, 2,4\% em expatriados não urbanos, $1,5 \%$ em estudantes, $0,2 \%$ em visitantes, $0,2 \%$ de expatriados para áreas urbanas e $0,2 \%$ em viajantes, com duração de viagem de mais de seis meses em praticamente de todos os casos de filariose bancroftiana; e com períodos de aparecimento dos primeiros sintomas para a filariose bancroftiana de 1 mês a 6 meses do retorno à terra natal (LIPNER, 2007)

Ou seja, ainda que o período pré-patente do parasito seja de 6 meses, pode ocorrer a transmissão da filariose em períodos menores do que 6 meses, ainda que raramente, o que dá sentido à elaboração deste estudo.

Os casos encontrados de filariose na década de 1950, em Porto Velho, foram considerados alóctones, e encontravam-se nesta região em períodos considerados menores do que o período pré-patente do parasito, entretanto a doença poderia ter surgido posteriormente durante os fluxos migratórios na década de 1980, quando da exploração do ouro nesta região, que recebeu migrantes de diversas partes do Brasil, incluindo aí, dos estados do Amazonas, Pará, Alagoas, e Pernambuco, com cidades endêmicas à época.

Ainda com este pensamento, na segunda guerra mundial, mais de 38.000 marinheiros americanos ficaram expostos à filariose no Pacífico Sul, sendo que aproximadamente 10.000 tiveram sinais e sintomas de febre filarial. Porém, somente 20 marinheiros desenvolveram a doença (PFARR et al., 2009).

Será possível, então, que a exposição de indivíduos que nunca tiveram contato com a filariose, a curto prazo, teriam tendência a diminuir os riscos de uma infecção crônica pelos sintomas iniciais serem mais exuberantes e seu tratamento ser mais precoce? Ainda não há resposta. 
No entanto, hipoteticamente transportando o cenário para Porto Velho e região, considerando que o quadro clínico dos indivíduos parasitados pela filariose em áreas não endêmicas é sabidamente mais exuberante, o diagnóstico e o tratamento precoces diminuiriam os riscos de disseminação e transmissão da doença? Em contraste, indivíduos de áreas endêmicas desenvolvem formas clínicas menos exuberantes ou sub-clinicas da doença, mantendo-se portanto mais tempo com filaremia, e transmitindo de maneira silenciosa a doença (PFARR et al., 2009).

O método diagnóstico empregado foi o da gota espessa, que tem como principal limitação a redução da sensibilidade na identificação de pacientes que apresentam baixa microfilaremia (FONTES; ROCHA, 2005). A sensibilidade desta técnica em indivíduos em que a microfilaremia é maior que $10 \mathrm{mf} / \mathrm{mL}$ representa $98,5 \%$, enquanto que em indivíduos com menos que $10 \mathrm{mf} / \mathrm{mL}$ é de $60 \%$ (LEITE, 2003).

Por ser um método rápido, prático e econômico é usualmente utilizado em larga escala nos estudos de campo, e permite, além do mais, o diagnóstico de outros filarídeos sanguíneos presentes na região amazônica.

O padrão ouro, que apresenta diferente metodologia, consiste em realizar a filtração de até $10 \mathrm{~mL}$ de sangue através de uma membrana de policarbonato com poros de 3 a 5 micra. Para a sua realização há necessidade de técnicos especializados para a coleta de sangue, geladeiras ou acondicionadores especiais para o sangue, e meios de transporte adequados. É um método caro e, em função das condições locais não foi possível a sua utilização neste trabalho.

Outros métodos de diagnóstico como a Imunocromatografia (ICT) e a sorologia através de método imunoenzimático (ELISA) são métodos mais sensíveis e podem diagnosticar antigenemia em pacientes com microfilaremias sub-patentes; porém, seus custos operacionais - 100 vezes mais caros que a gota espessa - o que, na maioria das vezes, dadas as características econômico-sociais do estudo, transforma-se em fator impeditivo para a realização de estudos de campo em grande escala.

Por outro lado, na programação para a realização de um teste diagnóstico devem ser consideradas as condições locais, meios de transporte, acondicionamento dos testes e laboratórios adequados, pois caso isto não aconteça poderá haver alterações significativas dos resultados (GASS et al., 2012). A escolha do método baseou-se nas condições locais. 
A Reação em Cadeia da Polimerase (PCR), método utilizado, mostrou ser uma ferramenta valiosa na avaliação da intensidade de mosquitos infectados em áreas endêmicas, substituindo, com vantagens, as técnicas convencionais de diagnóstico da infecção por W. bancrofti por dissecação (BOCKAIRE et al., 2000). Essa técnica, além de ter se mostrado mais sensível que a dissecação, é espécie específica e, principalmente, permite o processamento de um grande número de amostras em um curto espaço de tempo.

Embora todas as limitações da transmissão e disseminação da doença tenham sido discutidas, não podemos afirmar que um único fator seja o responsável pela não detecção da doença nesta região. Todos estes fatores podem ter contribuído de maneira direta e indireta para a não manutenção de um foco de filariose nesta região.

A imigração de haitanos para esta região, eventuais portadores de filariose, pode a longo prazo estabelecer um novo foco da doença, uma vez que o Haiti é um dos países com maior prevalência de filariose no mundo.

\section{CONSIDERAÇÕES FINAIS}

O pequeno número de parasitados e a baixa microfilaremia observados na década de 1950 em Porto Velho e Guajará Mirim foram insuficientes para implantação e manutenção da transmissão da filariose linfática nas áreas indenes avaliadas, podendo estar associados a fatores ambientais e ao mosquito vetor como descrito anteriormente, sem afirmarmos qual o fator decisivo para a não instalação de um foo de filariose nesta região.

Existe em abundância o vetor $C$. quinquefasciatus.

Não foram identificados mosquitos infectados pela técnica do PCR

Não foram detectados casos de infecção humana pela $W$. bancrofti nas áreas pesquisadas pelo método da gota espessa.

Não há transmissão, no momento do estudo, de bancroftose na área estudada.

É de extrema importância que os órgãos governamentais executem um plano de ação para que se realize uma pesquisa envolvendo todos os imigrantes haitianos nesta região, uma vez que pelos meios convencionais de pesquisa, 
através do consentimento livre e informado os haitianos não aceitaram ser voluntários para a realização do exame para a deteç̧ão da filariose bancroftiana. Caso essa pesquisa não seja realizada, o Brasil estará correndo o risco de apresentar um novo foco da doença muito em breve.

O presente estudo foi objeto de dois Trabalhos de Conclusão de Curso da Faculdade de Biologia da São Lucas, quatro comunicações em congressos nacionais e um trabalho publicado em revista indexada(APÊNDICE E).

\section{PROPOSTAS}

Informar aos profissionais de saúde dos resultados obtidos.

Aos casos suspeitos da doença, que esta seja notificada e investigada quanto a origem, se autóctone ou importada.

Melhora dos Indicadores Socioeconômicos com melhora da infraestrutura urbana, saneamento básico e ampliação dos níveis de escolaridade.

Pesquisa da filariose nos imigrantes haitianos.

Capacitação das unidades para diagnóstico de malária para diagnóstico também de bancroftose e outras filarioses. 


\section{REFERÊNCIAS ${ }^{21}$}

ABBASI, I.; GITHURE, J.; OCHOLA, J. J.; AGURE, R.; KOECH, D. K.; RAMZY, R. M.; WILLIAMS, S. A.; HAMBURGER, J. Diagnosis of Wuchereria bancrofti infection by the polymerase chain reaction employing patients' sputum. Parasitol Res., v. 85, n. 10, p. 844-849, 1999.

ADDISS, D. G.; BRADY, M. A. Morbidity management in the global programme to eliminate lymphatic filariasis: a review of the scientific literature. Filaria J., v. 6, 2007. Diponível em: <http://www.ncbi.nlm.nih.gov/pmc/articles/PMC1828725/>. Acesso em: 7 dez. 2012.

ALBUQUERQUE, M. F. P. M.; MORAIS, H. M. M. Decentralization of endemic disease control: an intervention model for combating bancroftian filariasis. Rev. Panam. Salud Publica, v. 1, n. 2, p. 155-163, 1997.

AMARAL, F.; DREYER, G.; FIGUEREDO-SILVA, J.; NOROES, J.; CAVALCANTI, A.; SAMICO, S. C.; SANTOS, A.; COUTINHO, A. Live adult worms detected by ultrasonography in human bancroftian filariasis. Am. J. Trop. Med. Hyg., v. 50, n. 6, p. 753-757, Jun. 1994.

AMARAL, F.; NORÕES, J.; DREYER, G. Uso da ultra-sonografia no diagnóstico da filariose linfática escrotal: relato de dois casos. Radiol. Bras., v. 28, p. 217-219, 1995.

AWADZI, K. Clinical picture and outcome of serious adverse events in the treatment of Onchocerciasis. Filaria J., v. 2, p. S6, Suppl. 1, 2003.

BARBOSA, R. M.; SOUTO, A.; EIRAS, A. E.; REGIS, L. Laboratory and field evaluation of an oviposition trap for Culex quinquefasciatus (Diptera: Culicidae). Mem. Inst. Oswaldo Cruz, Rio de Janeiro, v. 102, n. 4, p. 523-529, 2007.

BASANO, S. de A.; CAMARGO, J. D. E. S.; VERA, L. J.; VELASQUES, S. N.; OGAWA, G. M.; MEDEIROS, J. F.; FONTES, G.; CAMARGO, L. M. Investigation of the occurrence of Mansonella ozzardi in the State of Rondônia, Western Amazonia, Brazil. Rev. Soc. Bras. Med. Trop. Brasilia, v. 44, n. 5, p. 600-603, Oct. 2011.

BEURIA, M. K.; BAL, M. S.; MANDAL, N. N.; DAS, M. K. Antigenemia at 10 years after diethylcarbamazine treatment of asymptomatic microfilaraemic individuals: marginal conversion to infection-free state. Parasite Immunol., v. 24, n. 2, p. 109111, 2002.

BOCKARIE, M. J.; FISCHER, P.; WILLIAMS, S. A.; ZIMMERMAN, P. A.; GRIFFIN, L.; ALPERS, M. P.; KAZURA, J. W. Application of a polymerase chain reactionELISA to detect Wuchereria bancrofti in pools of wildcaught Anopheles punctulatus in

\footnotetext{
${ }^{21}$ De acordo com: ASSOCIAÇÃO BRASILEIRA DE NORMAS TÉCNICAS. NBR 6023: informação e documentação: referências: elaboração. Rio de Janeiro, 2002.
} 
filariasis control area in Papua New Guinea. Am. J. Trop. Med. Hyg. v. 62, n. 3, p. 363-367, 2000.

BOCKARIE, M. J.; TAVUL, L.; IBAM, I.; KASTENS, W.; HAZLETT, F.; TISCH, D. J.; ALPERS, M. P.; KAZURA, J. W. Efficacy of single-dose diethylcarbamazine compared with diethylcarbamazine combined with albendazole against Wuchereria bancrofti infection in Papua New Guinea. Am. J. Trop. Med. Hyg., v. 76, n. 1, p. 6266, Jan. 2007.

BONFIM, C.; ALVES, A.; COSTA, T. R.; ALENCAR, .F; PEDROZA, D.; PORTUGAL, J. L.; MEDEIROS, Z. Spatial analysis and privation index to identify urban areas with a high risk of lymphatic filariasis. Trop. Med. Int. Health, v. 16, n. 6, p. 748-755, Jun. 2011.

BONFIM, C.; NETTO, M. J.; PEDROZA, D.; PORTUGAL, J. L.; MEDEIROS, Z. A. Socioenvironmental composite index as a tool for identifying urban areas at risk of lymphatic filariasis. Trop. Med. Int. Health., v. 14, n. 8, p. 877-884, Aug. 2009.

BRASIL. Ministério da Saúde. Departamento de Erradicaçäo e Controle de Endemias. O controle das endemias no Brasil (de 1979 a 1984). Brasília, DF, 1985.

BRASIL. Ministério da Saúde. Filariose linfática: manual de coleta de amostras biológicas para diagnóstico de Filariose linfática por Wuchereria bancrofti. Brasília, DF, 2008.

BRASIL. Ministério da Saúde. Guia de vigilância epidemiológica e eliminação da filariose linfática. Brasília, DF, 2009. 79 p.

BRITO, A. C.; VILA-NOVA, M. C.; MARTINS ROCHA, D. A.; GOMES COSTA, L.; PINHEIRO DE ALMEIDA, W. A.; DA SILVA VIANA, L.; RAMALHO LOPES, R. J. R.; FONTES, G.; DA ROCHA, E. M.; REGIS, L. Prevalência da filariose canina causada por Dirofilaria immitis e Dipetalonema reconditum em Maceió, Alagoas, Brasil. Cad. Saúde Pública, v. 17, n. 6, p. 1497-1504, 2001.

CALHEIROS, C. M.; FONTES, G.; WILLIAMS, P.; ROCHA, E. M. Experimental infection of Culex (Culex) quinquefasciatus and Aedes (Stegomyia) aegypti with Wuchereria bancrofti. Mem. Inst. Oswaldo Cruz, Rio de Janeiro, v. 93, n. 6, p. 855860, Nov./Dec. 1998.

CAMPOS, L. E. M.; PEREIRA, L. F. F. Eosinofilia pulmonar. J. Bras. Pneumol., v. 35, n. 6, p. 561-573, 2009. Disponível em: <http://www.scielo.br/pdf/jbpneu/v35n6/v35n6a10.pdf>. Acesso em: 2 out. 2012.

CARVALHO, G. A. et al. Vector competence of Culex quinquefasciatus (Say, 1823) exposed to different densities of microfilariae of Dirofilaria immitis (Leidy, 1856). Rev. Bras. Entomol., v. 52, n. 4, p. 658-662, 2008. 
CENTERS FOR DISEASE CONTROL AND PREVENTION. Vectors of lymphatic filariasis. Updated: 2 Nov. 2010. Disponível em:

<http://www.cdc.gov/parasites/lymphaticfilariasis/gen_info/vectors.html>. Acesso em: 15 jan. 2013.

CENTERS FOR DISEASE CONTROL AND PREVENTION. Division of parasitic diseases and malaria. Parasites and health: filariasis: life cycle of Wuchereria bancrofti. Disponível em: <http://www.dpd.cdc.gov/dpdx/HTML/Frames/AF/Filariasis/body_Filariasis_w_bancrofti.htm>. Acesso em : 05 nov. 2012b.

CENTERS FOR DISEASE CONTROL AND PREVENTION. Division of Parasitic Diseases and Malaria. Parasite image library: filariasis. Disponível em: <http://www.dpd.cdc.gov/dpdx/HTML/ImageLibrary/Filariasis_il.htm>. Acesso em: 05 nov. 2012a.

CHANDRA, G. et al. Effect of seasonal variations on the development of Wuchereria larvae in Culex quinquefasciatus. Basic Appl. Biomed., v. 5, p. 21-24, 1997.

CHANDRA, G. Nature limits filarial transmission. Parasit Vectors, v. 1, p. 13, 2008.

CHANDRASHEKAR, R.; CURTIS, K. C.; RAMZY, R. M.; LIFTIS, F.; LI, B. W.; WEIL, G. J. Molecular cloning of Brugia malayi antigens for diagnosis of lymphatic filariasis. Mol. Biochem. Parasitol., v. 64, n. 2, p. 261-271, 1994.

CHEN, C. C.; CHEN, C. S. Brugia pahangi: effects of melanization on the uptake of nutrients by microfilariae in vitro. Exp. Parasito., v. 81, n. 1, p. 72-78, 1995.

CHRISTENSEN, B. M.; SUTHERLAND, D. R.; GLEASON, L.N. Defense reactions of mosquitoes to filarial worms: comparative studies on the response of three different mosquitoes to inoculated Brugia pahangi and Dirofilaria immitis microfilariae. $\mathbf{J}$. Invertebr. Pathol., v. 44, n. 3, p. 267-274, 1984

CHRISTENSEN, B. M.; TRACY, J. W. Arthropod-transmitted parasites: mechanisms of immune interaction. Am. Zool., v. 29, n. 2, p. 387-398, 1989.

CHULARERK, P.; DESOWITZ, R. S. A simplified membrane filtration technique for the diagnosis of microfilaremia. J. Parasitol., v. 56, n. 3, p. 623-624, 1970.

DAS, G. C.; SEN, S. B. Chylous arthritis. Br. Med. J., v. 2, n. 5596, p. 27-29, Apr 1968.

DAS, P. K.; VANMAIL, P. Probability risk transmission matrix as a decisison tool for assessing methods of transmission interruption of Wulchereria bancrofti. Epidemiol. Infect., v. 136, n. 4, p. 520-524, 2008

DEANE, L. M.; ROSA, D.; RACHOU, R. G.; MARTINS, J. S.; COSTA, A.; GOMES, H. M.; CARVALHO, M. E. A filariose bancroftiana em Maceió, Alagoas: Resultado de um inquérito realizado em 1952. Revista Brasileira de Malariologia e Doenças Tropicais, v. 5, n. 1, p. 17-22, 1953. 
DEBRAH, A. Y.; MAND, S.; MARFO-DEBREKYEI, Y.; BATSA, L.; PFARR, K.; LAWSON, B.; TAYLOR, M.; ADJEI, O.; HOERAUF, A. Reduction in levels of plasma vascular endothelial growth factor-A and improvement in hydrocele patients by targeting endosymbiotic Wolbachia sp. in Wuchereria bancrofti with Doxycycline. Am. J. Trop. Med. Hyg., v. 80, n. 6, p. 956-963, Jun 2009.

DEMBELE, B.; COULIBALY, Y.I.; DOLO, H.; KONATE, S.; COULIBALY, S.Y.; SANOGO, D.; SOUMAORO, L.; COULIBALY, M.E.; DOUMBIA, S.S.; DIALLO, A.A.; TRAORE, S.F.; DIAMAN KEITA, A.; FAY, M.P.; NUTMAN, T.B.; KLION, A.D. Use of high-dose, twice-yearly albendazole and ivermectin to suppress Wuchereria bancrofti microfilarial levels. Clin. Infect. Dis., Chicago, v. 51, n. 11, p. 1229-1235, 2010.

DISSANAYAKE, S.; GALAHITIYAWA, S. C.; ISMAIL, M. M. Immune complexes in Wuchereria bancrofti infection in man. Bull. World Health Organ. v. 60, n. 6, p. 919927, 1982.

DISSANAYAKE, S. et al. Evaluation of a recombinant parasite antigen for the diagnosis of lymphatic filariasis. Am. J. Trop. Med. Hyg., v. 50, n. 6, p. 727-734, 1994.

DREYER, G.; ADDISS, D.; NOROES, J.; AMARAL, F.; ROCHA, A.; COUTINHO, A. Ultrasonographic assessment of the adulticidal efficacy of repeat high-dose ivermectin in bancroftian filariasis. Trop. Med. Int. Health, v. 1, p. 427-432, 1996.

DREYER, G.; ADDISS, D.; ROBERTS, J.; NORÕES, J. Progression of lymphatic vessel dilatation in the presence of living adult Wuchereria bancrofti. Trans. R. Soc. Trop. Med. Hyg., v. 96, p. 157-161, 2002.

DREYER, G.; BÉLIZ, Z. M.; VERGETTI, G.; VERGETTI, A.; CAFE T, FONTES G. Autochthonous Wuchereria bancrofti microfilaremia in the city of Maceió-AlagoasBrazil. Mem. Inst. Oswaldo Cruz, Rio de Janeiro, v. 86, n. 4, p. 495-496, 1991.

DREYER, G.; DREYER, P.; PIESSENS, W. P. Extralymphatic disease due to bancroftian filariasis. Braz. J. Med. Biol. Res., v. 32. n. 12, p. 1467-1472, Dec 1999.

DREYER, G.; MATTOS, D.; NORÕES, J. Chyluria. Rev. Assoc. Med. Bras., v. 53, n. 5, p. 460-464, Sept.-Oct. 2007.

DREYER, G. Diagnóstico parasitológico da filariose bancroftiana. Rev. Soc. Bras. Med. Trop., Uberaba, v. 27, p. 162-168, 1994. Suppl. 4.

FARID, H. A.; MORSY, Z. S.; HELMY, H.; RAMZY, R. M.; EL SETOUHY, M.; WEIL, G. J. A critical appraisal of molecular xenomonitoring as a tool for assessing progress toward elimination of Lymphatic Filariasis. Am. J. Trop. Med. Hyg., v. 77, n. 4, p. 593-600, Oct 2007.

FARID, H. A.; MORSY, Z. S.; HASSAN, A. N.; HAMMAD, R. E.; FARIS, R.; KANDIL, A. M.; AHMED, E. S.; WEIL, G. J. The impact of environmental and entomological factors on intervillage filarial focality in the Nile Delta. J. Egypt Soc. Parasitol., v. 30, n. 2, p. 469-485, Aug 2000. 
FERRI, E.; BAIN, O.; BARBUTO, M.; MARTIN, C.; LO, N.; UNI, S.; LANDMANN, F.; BACCEI, S.G.; GUERRERO, R.; DE SOUZA LIMA, S.; BANDI, C.; WANJI, S.; DIAGNE, M.; CASIRAGHI, M. New insights into the evolution of Wolbachia infections in filarial nematodes inferred from a large range of screened species. PLoS One, $v$. 6, n. 6, p. e20843, 2011. Disponível em: <http://www.ncbi.nlm.nih.gov/pmc/articles/PMC3120775/pdf/pone.0020843.pdf>. Acesso em: 30 out. 2012.

FISCHER, P.; SUPALI, T.; MAIZELS, R. M. Lymphatic filariasis and Brugia timori: prospects for elimination. Trends Parasitol., v. 20, n. 8, p. 351-355, Aug 2004.

FONSECA, D. M.; SMITH, J. L.; WILKERSON, R. C.; FLEISCHER, R. C. Pathways of expansion and multiple introductions illustrated by large genetic differentiation among worldwide populations of the southern house mosquito. Am. J. Trop. Med. Hyg., v. 74, n. 2, p. 284-289, Feb 2006.

FONTES, G.; BRAUN, R. F.; FRAIHA NETO, H.; VIEIRA, J. B.; PADILHA, S. S.; ROCHA, R. C.; DA ROCHA, E. M. Filariose linfática em Belém, Estado do Pará, norte do Brasil e a perspectiva de eliminação. Rev. Soc. Bras. Med. Trop., Uberaba, v. 38, n. 2, p. 131-136, 2005.

FONTES, G.; LEITE, A. B.; DE LIMA, A. R.; FREITAS, H.; EHRENBERG, J. P.; DA ROCHA, E. M. Lymphatic filariasis in Brazil: epidemiological situation and outlook for elimination. Parasit. Vectors, v. 5, p. 272, 2012.

FONTES, G.; ROCHA, E. M.; BRITO, A. C.; ANTUNES, C. M. Lymphatic filariasis in brazilian urban area (Maceió, Alagoas). Mem. Inst. Oswaldo Cruz, Rio de Janeiro, v. 93, n. 6, p. 705-710, Nov./Dec. 1998.

FONTES, G.; ROCHA, E. M.; BRITO, A. C.; FIREMAN, F. A.; ANTUNES, C. M. The microfilarial periodicity of Wuchereria bancrofti in northeastern Brazil. Ann. Trop. Med. Parasitol., v. 94, n. 4, p. 373-379, 2000.

FONTES, G.; ROCHA, E. M. M. Filariidea: Wuchereria bancrofti - Filariose linfática. In: NEVES, D. P.; MELO, A. L.; GENARO, O.; LINARDI, P. M. (Org.). Parasitologia humana. 11. ed. Rio de Janeiro: Atheneu, 2005. p. 208-218.

FONTES, G. Aspectos epidemiológicos da filariose linfática causada pela Wuchereria bancrofti no Estado de Alagoas. 1996. Tese (Doutorado) - Instituto de Ciências Biológicas, Universidade Federal de Minas Gerais, Belo Horizonte, 1996.

FRANCO, O.; SILVA-LIMA, D. M. Alguns aspectos das atividades contra a filariose bancroftiana no Brasil. Rev. Bras. Malariol. D. Trop., v. 19, p. 73-89, 1967.

FRANCO-PAREDES, C.; ROUPHAEL, N.; MÉNDEZ, J.; FOLCH, E.; RODRÍGUEZMORALES, A.J.; SANTOS, J.I.; HURST, J.W.Cardiac manifestations of parasitic infections part 3: pericardial and miscellaneous cardiopulmonary manifestations. Clin. Cardiol., v. 30, n. 6, p. 277-280, Jun. 2007. 
FREEDMAN, D.O.; PLIER, D.A.; DE ALMEIDA, A.B.; DE OLIVEIRA, A.L.; MIRANDA, J.; BRAGA, C. Effect of aggressive prolonged diethylcarbamazine therapy on circulating antigen levels in bancroftian filariasis. Trop. Med. Int. Health. v. 6, n. 1, p. 37-41, 2001.

FREEDMAN, D. O.; NUTMAN, T. B. Filariasis. In: BALOWS, A.; HAUSLER JR., W. J.; LENNETTE, E. H. (Ed.). Laboratory diagnosis of infections diseases: principles and practice. New York: Springer Verlag, 1989. v. 1. p. 863-71.

FREITAS, H.; VIEIRA, J. B.; BRAUN, R.; MEDEIROS, Z.; ROCHA, E. M.; AGUIARSANTOS, A.; FRAIHA, H.; ROCHA, A. Workshop to evaluate the epidemiologic situation of lymphatic filariasis in the Municipality of Belém, Pará, Northern Brazil. Rev. Soc .Bras. Med. Trop., Uberaba, v. 41, n. 2, p. 212-216, Mar.-Apr. 2008.

FURTADO, A. F.; ABATH, F. G.; REGIS, L.; GOMES, Y. M.; LUCENA, W. A.; FURTADO, P. B.; DHALIA, R.; MIRANDA, J. C.; NICOLAS, L. Improvement and application of a polymerase chain rection system for detection of Wuchereria bancrofti in Culex quinquefasciatus and human blood samples. Mem. Inst. Oswaldo Cruz, Rio de Janeiro, v. 92, n. 1, p. 85-86, 1997.

GASS, K.; BEAU DE ROCHARS, M. V.; BOAKYE, D.; BRADLEY, M.; FISCHER, P.U.; GYAPONG, J.; ITOH, M.; ITUASO-CONWAY, N.; JOSEPH, H.; KYELEM, D.; LANEY, S.J.; LEGRAND, A.M.; LIYANAGE, T.S.; MELROSE, W.; MOHAMMED, K.; PILOTTE, N.; OTTESEN, E.A.; PLICHART, C.; RAMAIAH, K.; RAO, R.U.; TALBOT, J.; WEIL, G.J.; WILLIAMS, S.A.; WON, K.Y.; LAMMIE, P. A multicenter evaluation of diagnostic tools to define endpoints for programs to eliminate bancroftian filariasis. PLoS Negl. Trop. Dis. v. 6, n. 1, p. e1479, Jan. 2012.

GOODMAN, D. S.; ORELUS, J. N.; ROBERTS, J. M.; LAMMIE, P. J.; STREIT, T. G. PCR and mosquito dissection as tools to monitor filarial infection levels following mass treatment. Filaria J. v. 2, p. 11, 2003. Disponível em: <http://www.ncbi.nlm.nih.gov/pmc/articles/PMC169178/pdf/1475-2883-2-11.pdf>.

Acesso em: 3 dez. 2012.

HAIRSTON, N. G.; MEILLON B. On the inefficiency of transmission of Wuchereria bancrofti from mosquito to human host. Bull World Health Organ., v. 38, n. 6, p. 935-941, 1968.

HAWKING, F.; GAMMAGE, K. The periodic migration of microfilariae of Brugia malayi and its response to various stimuli. Am. J. Trop. Med. Hyg., v. 17, p. 724729, 1968.

HOTEZ, P. J.; SAVIOLI, L.; FENWICK, A. Neglected tropical diseases of the Middle East and North Africa: review of their prevalence, distribution, and opportunities for control. PLoS Negl Trop Dis., v. 6, n. 2, p. e1475, 2012. Disponível em: <http://www.ncbi.nlm.nih.gov/pmc/articles/PMC3289601/pdf/pntd.0001475.pdf>. Acesso em: 8 nov. 2012. 
JOHNSON, P.; MACKENZIE, C.D.; DENHAM, D. A.; SUSWILLO, R. R. The effect of diethylcarbamazine on the in vitro serum-mediated adherence of feline granulocytes to microfilariae of Brugia pahangi. Trop. Med. Parasitol., v. 39, n. 4, p. 291-294, 1988

KASILI, S.; OYIEKE, F.; WAMAE, A.K.; BISEN, C.; MBOGO, C. Seasonal changes of infectivity rates of Bancroftian filariasis vectors in coast province, Kenya. J. Vector Borne Dis., v. 46, n. 3, p. 219-224, 2009.

KATHOLI, C. R.; TOÉ, L.; MERRIWEATHER, A.; UNNASCH, T. R. Determining the prevalence of Onchocerca volvulus infection in vector populations by polymerase chain reaction screening of pools of black flies. J. Infect. Dis., v. 172, n. 5, p. 14141417, 1995.

KAZURA, J. W. Higher-dose, more frequent treatment of Wuchereria bancrofti. Clin. Infect. Dis., Chicago, v. 51, n.11, p. 1236-1237, Dec. 2010.

KILPATRICK, A. M.; KRAMER, L. D.; JONES, M. J.; MARRA, P. P.; DASZAK, P.; FONSECA, D. M. Genetic influences on mosquito feeding behavior and the emergence of zoonotic pathogens. Am. J. Trop. Med. Hyg., v. 77, n. 4, p. 667-671, 2007.

KRISHNAMOORTHY, K. et al. Vector survival and parasite infection: the effect of Wuchereria bancrofti on its vector Culex quinquefasciatus. Parasitology, v. 129, pt. 1, p. 43-50, 2004.

LAMMIE, P. J.; HIGHTOWER, A. W.; EBERHARD, M. L. The age-specific prevalence of antigenemia in a Wuchereria bancrofti-exposed population. Am. J. Trop. Med. Hyg., v. 51, n. 3, p. 348-355, 1994.

LEITE, A. B. Comparação de diferentes técnicas para o diagnóstico laboratorial da filariose linfática bancroftiana. Trabalho de Conclusão de Curso - Centro de Ciências Biológicas, Departamento de Patologia, Universidade Federal de Alagoas, Maceio, 2003.

LEITE, A. B.; LIMA, A. R.; LEITE, R. B.; SANTOS, R. V.; GONÇALVES, J. E.; ROCHA E. M.; FONTES, G. Assessment of family and neighbors of an individual infected with Wuchereria bancrofti from a non-endemic area in the city of Maceió, Brazil. Braz. J. Infect Dis., v. 14, n. 2, p. 125-128, 2010.

LIMA, A. W.; MEDEIROS, Z.; SANTOS, Z. C.; COSTA, G. M.; BRAGA, C. Adverse reactions following mass drug administration with diethylcarbamazine in lymphatic filariasis endemic areas in the Northeast of Brazil. Rev. Soc. Bras. Med. Trop., Uberaba, v. 45, n. 6, p. 745-750, 2012.

LIPNER, E. M.; LAW, M. A.; BARNETT, E.; KEYSTONE, J. S.; VON SONNENBURG, F.; LOUTAN, L.; PREVOTS, D. R.; KLION, A. D.; NUTMAN, T. B. Geosentinel Surveillance Network.Filariasis in travelers presenting to the GeoSentinel Surveillance Network. PLoS Negl. Trop. Dis., v. 1, n. 3, p. e88, 2007. 
LO, N.; PARASKEVOPOULOS, C.; BOURTZIS, K.; O'NEILL, S. L.; WERREN, J.H.; BORDENSTEIN, S. R.; BANDI, C. Taxonomic status of the intracellular bacterium Wolbachia pipientis. Int. J. Syst. Evol. Microbiol., v. 57, pt. 3, p. 654-657, 2007.

LUCENA, W. A.; DHALIA, R.; ABATH, F. G.; NICOLAS, L.; REGIS, L. N.; FURTADO, A. F. Diagnosis of Wuchereria bancrofti infection by the polymerase chain reaction using urine and day blood samples from amicrofilaraemic patients. Trans. R. Soc. Trop. Med. Hyg., v. 92, n. 3, p. 290-293, 1998.

LUSTIGMAN, S.; PRICHARD, R. K.; GAZZINELLI, A.; GRANT, W. N.; BOATIN, B. A.; MCCARTHY, J. S.; BASÁÑ̃Z, M. G. A research agenda for helminth diseases of humans: the problem of helminthiases. PLoS Negl. Trop. Dis., v. 6, n. 4, p. e1582, 2012.

MATTOS, D.; DREYER, G. A complexidade do custo socioeconômico da filariose linfática. Rev. Soc. Bras. Med. Trop., Uberaba, v. 41, n. 4, p. 399-403, jul./ago. 2008.

MCCARTHY, J. Diagnosis of lymphatic filarial infections. In: NUTMAN, T. B. (Org.). Lymphatic filariasis. London: Imperial College Press, 2000. p. 127-150.

MCCARTHY, J. S. et al. Evaluation of a polymerase chain reaction-based assay for diagnosis of Wuchereria bancrofti infection. J. Infect. Dis., v. 173, n. 6, p. 15101514, 1996.

MICHALSKI, M. L; GRIFFITHS, K. G.; WILLIAMS, S. A.; KAPLAN, R. M.; MOORHEAD, A. R. The NIH-NIAID filariasis research reagent resource center. PLOS Negl. Trop. Dis., Nov. 2011.

MORE, S. J.; COPEMAN, D. B. A highly specific and sensitive monoclonal antibodybased ELISA for the detection of circulating antigen in bancroftian filariasis. Trop. Med. Parasitol., v. 41, p. 403-406, 1990.

NANDURI, J.; KAZURA, J. W. Clinical and laboratory aspects of filariasis. Clin. Microbiol. Rev., v. 2, n. 1, p. 39-50, 1989.

NOORDIN, R.; ITOH, M.; KIMURA, E.; ABDUL RAHMAN, R.; RAVINDRAN, B.; MAHMUD, R.; SUPALI, T.; WEERASOORIYA, M. Multicentre evaluations of two new rapid IgG4 tests (WB rapid and panLF rapid) for detection of lymphatic filariasis. Filaria J. v. 6, p. 9. Oct. 2007. Disponível em: <http://www.ncbi.nlm.nih.gov/pmc/articles/PMC2174453/pdf/1475-2883-6-9.pdf>. Acesso em: 8 nov. 2012.

NUTMAN, T. B.; MILLER, K.D.; MULLIGAN, M.; OTTESEN, E.A. Loa loa infection in temporary residents of endemic regions: recognition of a hyperresponsive syndrome with characteristic clinical manifestations. J. Infect. Dis. v. 154, n. 1, p. 10-18, Jul. 1986.

ORIHEL, T. C. Filariae. In: BEAVER, P. C.; JUNG, R. C. Animals agents and vectors of human disease. 5th ed. Philadelphia: Lea \& Febiger, 1985. cap.12, p. 171-191. 
PAILY, K. P.; HOTI, S. L.; MANONMANI, A. M.; BALARAMAN, K. Longevity and migration of Wuchereria bancrofti infective larvae and their distribution pattern in relation to the resting and feeding behaviour of the vector mosquito, Culex quinquefasciatus. Ann. Trop. Med. Parasitol., v. 89, n. 1, p. 39-47, Feb. 1995.

PAILY, K. P.; HOTI, S. L.; BALARAMAN, K. Development of lymphatic filarial parasite Wuchereria bancrofti (Spirurida: Onchocercidae) in mosquito species (Diptera: Culicidae) fed artificially on microfilaremic blood. J. Med. Entomol., v. 43, p. 1222-1226, 2006.

PAILY, K. P.; HOTI, S. L.; DAS, P. K. A review of the complexity of biology of lymphatic filarial parasites. J. Parasit. Dis., v. 33, n. 1-2, p. 3-12, Dec. 2009.

PALUMBO, E. Filariasis: diagnosis, treatment and prevention. Acta Biomed., v. 79, n. 2, p. 106-109, 2008.

PEIXOTO, C. A.; SANTOS, A. C.; AYRES, C. F. Molecular evidence for apoptosis in microfilariae of Wuchereria bancrofti induced by diethylcarbamazine. Parasitol. Res., v. 103, n. 3, p. 717-721, 2008.

PFARR, K. M.; DEBRAH, A. Y.; SPECHT, S.; HOERAUF, A. Filariasis and lymphoedema. Parasite Immunol., v. 31, n. 11, p. 664-672, 2009.

PIESSENS, W. F.; PARTONO, F. Host-vector-parasite relationships in Human Filariasis. In: WEINSTEIN, L.; FIELDS, B. N. (Org.). Semminars in infections diseases. New York: Thieme-Stratton, 1980. p. 131-152.

PINKSTON, P. et al. Acute tropical pulmonary eosinophilia: characterization of the lower respiratory tract inflammation and its response to therapy. J. Clin. Invest., v. 80, n. 1, p. 216-225, 1987.

RACHOU, R. G.; LACERDA, N. B.; COSTA, A. Inquérito hemoscópico para pesquisa de microfilárias em Porto Velho, capital do território do Guaporé. Rev. Bras. Malariol. D. Trop., v. 6, p. 501-503, 1954.

RACHOU, R. G. Conceito e programa de profilaxia da filariose bancroftiana no Brasil. Rev. Bras. Malariol. D. Trop., v. 12, p. 11-40, 1960.

RACHOU, R. G. Distribuição geográfica das Filarioses humanas no Brasil. Rev. Bras. Malariol. D. Trop., v. 9, p. 79-100, 1957.

RAMACHANDRAN, C. P. A guide to methods and techniques in filariasis investigations. Kuala Lumpur, Malasya: Di-Chetak Di-Jabatan Chetak Kerajaan oleh Mohamed bin Abdullah. Institute for Medical Research, Bulletin, n. 15, p. 1-39, 1970.

ROCHA, A. Filariose bancroftiana: avaliação dos testes de diagnóstico disponíveis frente às diversas formas clínicas da bancroftose. 2004. Tese (Doutorado em Biologia Celular e Molecular) - Instituto Oswaldo Cruz, Recife, 2004. 
SASA, M. Human filariasis: a global survey of epidemiology and control. Tokyo: University of Tokyo Press, 1976.

SERRÃO, M. L.; LABARTHE N.; LOURENÇO DE OLIVEIRA, R. Vectorial competence of Aedes aegypti (Linnaeus 1762) Rio de Janeiro strain, to Dirofilaria immitis (Leidy 1856). Mem. Inst. Oswaldo Cruz, Rio de Janeiro, v. 96, n. 5, p. 593598, 2001.

SHENOY, R. K. Clinical and pathological aspects of filarial lymphedema and its management. Korean J. Parasitol., v. 46, n. 3, p. 119-125, 2008.

SIMONSEN, P. E.; MWAKITALU, M. E. Urban Iymphatic filariasis. Parasitol. Res., v. 112, n. 1, p. 35-44, Jan. 2013. Disponível em: <http://pubmedcentralcanada.ca/pmcc/articles/PMC3536942/pdf/436_2012_Article_3 226.pdf>. Acesso em: 20 jan. 2013.

SLATKO, B. E.; TAYLOR, M. J.; FOSTER, J. M. The Wolbachia endosymbiont as an anti-filarial nematode target. Symbiosis v. 51, n. 1, p. 55-65, 2010.

SNOW, L. C.; MICHAEL, E. Transmission dynamics of Iymphatic filariasis: densitydependence in the uptake of Wuchereria bancrofti microfilariae by vector mosquitoes. Med. Vet. Entomol., v. 16, n. 4, p. 409-4023, 2002.

SUMADHYA, D. F.; CHATURAKA, R.; SENAKA, R. Current evidence on the use of antifilarial agents in the management of bancroftian filariasis. J. Trop. Med., v. 2011, p. 175941, 2011. Disponível em: <http://www.ncbi.nlm.nih.gov/pmc/articles/PMC3018634/pdf/JTM2011-175941.pdf>. Acesso em: 5 jan. 2013.

TANG, T. H.; LÓPEZ-VÉLEZ, R.; LANZA, M.; SHELLEY, A. J.; RUBIO, J. M.; LUZ, S. L. Nested PCR to detect and distinguish the sympatric filarial species Onchocerca volvulus, Mansonella ozzardi and Mansonella perstans in the Amazon Region. Mem. Inst. Oswaldo Cruz, v. 105, n. 6, p. 823-828, 2010

UDALL, D. N. Recent updates on onchocerciasis: diagnosis and treatment. Clin. Infect. Dis., Chicago, v. 44, n. 1, p. 53-60, 2007.

WEIL, G. J.; LAMMIE, P. J.; WEISS, N. The ICT filariasis test: a rapid-format antigen test for diagnosis of bancroftian filariasis. Parasitol. Today, v. 13, n. 10, p. 401-404, 1997.

WHITE, G. B. Lymphatic filariasis. In: WORLD HEALTH ORGANIZATION. Division of Vector Biology and Control. Geographical distribution of arthropod-borne diseases and their principal vectors. Geneva: WHO, 1989. p. 23-34.

WILLIAMS, S. A.; NICOLAS, L.; LIZOTTE-WANIEWSKI, M.; PLICHART, C.; LUQUIAUD, P.; NGUYEN, L. N.; MOULIA-PELAT, J. P. A polimerase chain reaction assay for the detection of Wuchereria bancrofti in blood samples from French Polynesia. Trans. R. Soc. Trop. Med. Hyg., v. 90, n. 4, p.384-387, 1996. 
WORLD HEALTH ORGANIZATION. Global programme to eliminate lymphatic filariasis: progress report on mass drug administrations in 2007. Wkly. Epidemiol. Rec., Geneve, v. 83, n. 37-38, p. 333-348, 2008.

WORLD HEALTH ORGANIZATION. Global programme to eliminate lymphatic filariasis. Wkly Epidemiol Rec., Geneve, v. 82, n. 42, p. 361-380, 2007.

WORLD HEALTH ORGANIZATION. Global programme to eliminate lymphatic filariasis: progress report on mass drug administration, 2010. Wkly. Epidemiol. Rec., Geneve, v. 86, n. 35, p. 377-388, Aug. 2011.

WORLD HEALTH ORGANIZATION. Lymphatic filariasis: the disease and its control: fifth report of the WHO Expert Commitee on Filariasis. Geneva: WHO, 1992. (Technical Reports Series, n. 82).

WYND, S.; MELROSE, W. D.; DURRHEIM, D. N.; CARRON, J.; GYAPONG, M. Understanding the community impact of lymphatic filariasis: a review of the sociocultural literature. Bull. World Health Organ., v. 85, n. 6, p. 493-498, 2007.

ZELDENRYK, L. M.; GRAY, M.; SPEARE, R.; GORDON, S.; MELROSE, W. The emerging story of disability associated with lymphatic filariasis: a critical review. PLoS Negl. Trop. Dis., v. 5, n. 12, p. e1366, Dec. 2011. Disponível em: <http://www.ncbi.nlm.nih.gov/pmc/articles/PMC3246437/pdf/pntd.0001366.pdf>. Acesso em: 11 nov. 2012.

ZHONG, M.; MCCARTHY, J.; BIERWERT, L.; LIZOTTE-WANIEWSKI, M.; CHANTEAU, S.; NUTMAN, T. B.; OTTESEN, E. A.; WILLIAMS, S. A. A polymerase chain reaction assay for detection of the parasite Wuchereria bancrofti in human blood samples. Am. J. Trop. Med. Hyg., v. 54, n. 4, p. 357-363, 1996. 


\section{APÊNDICE A - Ficha de coleta entomológica}

\section{UNIVERSIDADE DE SÃO PAULO \\ INSTITUTO DE CIÊNCIAS BIOMÉDICAS 5}

\section{FICHA DE COLETA ENTOMOLÓGICA}

Número de registro: data: 1

Endereço:

Cood. GPS: S w

Temperatura Max:__Temperatura Mim:__ Temperatura média:

Umidade Max: Umidade Min: Umidade média:

Horário de inicio: Horário do termino:

Lua: nova ( ) crescente ( ) cheia( ) minguante ( )

Chuva: 0 ( ) fraca ( ) moderada ( ) forte ( ) muito forte ( )

Neblina: 0 ( ) fraca ( ) moderada ( ) forte ( ) muito forte ( )

Fumaça: 0 ( ) fraca ( ) moderada ( ) forte ( ) muito forte ( )

Vento: 0 ( ) fraca ( ) moderada ( ) forte ( ) muito forte ( )

\section{Ambientes de coleta}

\section{Intradomiciliar ( )}

Tipo de captura: CDC ( ) landing capture ( ) outras:

Resultado: positiva ( ) negativa ( ) Número de espécimes:

Peridomiciliar ( )

Tipo de captura: CDC ( ) landing capture ( ) outras:

Resultado: positiva ( ) negativa ( ) Número de espécimes:

Assinatura do supervisor de coleta: 


\title{
APÊNDICE B - Ficha de cadastro domiciliar
}

\author{
UNIVERSIDADE DE SÃO PAULO \\ INSTITUTO DE CIÊNCIAS BIOMÉDICAS 5 \\ FICHA DE CADASTRO DOMICILIAR
}

Registro:

Rua: $\mathrm{N}^{\circ}$

Bairro: Proprietário:

\begin{tabular}{|l|l|l|}
\hline Atividade realizada & Data & Responsável técnico \\
\hline & & \\
\hline & & \\
\hline & & \\
\hline
\end{tabular}




\section{APÊNDICE C - Termo de consentimento dos moradores}

\section{PROJETO FILARIOSE 2008}

\section{Termo de Consentimento Livre e Esclarecido}

Conforme acabamos de explicar, o Projeto Filariose, consiste na retirada de uma gota de sangue, em exame semelhante ao da malária. Este exame será realizado por pessoas treinadas para esse fim, e então confeccionada uma lâmina que posteriormente será examinada. 0 exame específico desta lâmina para este fim não é realizado rotineiramente em Porto Velho.

Todas as lâminas realizadas serão examinadas e os resultados serão entregues aos participantes. Caso algum dos participantes tenha um resultado positivo, o mesmo será tratado e acompanhado pela equipe, e uma nova investigação em sua residência e vizinhança será realizada.

TODOS OS MORADORES QUE DESEJEM PARTICIPAR DO PRESENTE ESTUDO E QUE PERMITAM A SUA COLETA PODEM SE DIRIGIR A UM DE NOSSOS COLABORADORES PARA O CADASTRAMENTO. A ACEITAÇÃO DA COLETA DO SANGUE POR NOSSOS COLABORADORES COMPREENDE NA ACEITAÇÃO AUTOMÁTICA DESTE TERMO DE CONSENTIMENTO ESCLARECIDO PARA PARTICIPAÇÃO DO PROJETO FILARIOSE. NA EVENTUAL DESISTÊNCIA DE PARTICIPAÇÃO, O SANGUE NÃO SERÁ COLHIDO, MESMO JÁ TENDO SIDO FEITO O CADASTRO.

COORDENAÇÃO DO PROJETO

Nome:

DN $\quad$ I I

Declaro que fui esclarecido sobre o que é o projeto filariose, e como é a coleta do sangue e suas eventuais complicações.

( ) aceito participar ( ) não aceito participar

Assinatura : 


\section{APÊNDICE D - Termo de consentimento escolares}

\section{PROJETO FILARIOSE 2008}

\section{Termo de Consentimento Livre e Esclarecido}

Conforme acabamos de explicar, o Projeto Filariose, consiste na retirada de uma gota de sangue, em exame semelhante ao da malária. Este exame será realizado por pessoas treinadas para esse fim, e então confeccionada uma lâmina que posteriormente será examinada. 0 exame específico desta lâmina para este fim não é realizado rotineiramente em Porto Velho.

Todas as lâminas realizadas serão examinadas e os resultados serão entregues aos participantes. Caso algum dos participantes tenha um resultado positivo, o mesmo será tratado e acompanhado pela equipe, e uma nova investigação em sua residência e vizinhança será realizada.

TODOS OS ALUNOS QUE DESEJEM PARTICIPAR DO PRESENTE ESTUDO E QUE PERMITAM A SUA COLETA PODEM SE DIRIGIR A UM DE NOSSOS COLABORADORES PARA O CADASTRAMENTO. A ACEITAÇÃO DA COLETA DO SANGUE POR NOSSOS COLABORADORES COMPREENDE NA ACEITAÇÃO AUTOMÁTICA DESTE TERMO DE CONSENTIMENTO ESCLARECIDO PARA PARTICIPAÇÃO DO PROJETO FILARIOSE. NA EVENTUAL DESISTÊNCIA DE PARTICIPAÇÃO, O SANGUE NÃO SERÁ COLHIDO, MESMO JÁ TENDO SIDO FEITO O CADASTRO.

COORDENAÇÃO DO PROJETO

Nome:

DN $\quad$ I I I

Declaro que fui esclarecido sobre o que é o projeto filariose, e como é a coleta do sangue e suas eventuais complicações.

( ) aceito participar

) não aceito participar

Assinatura : 
APÊNDICE E - Artigo publicado 


\title{
Survey of Bancroftian filariasis infection in humans and Culex mosquitoes in the western Brazilian Amazon region: implications for transmission and control
}

\author{
Rodolfo Luís Korte ${ }^{[1],[2]}$, Gilberto Fontes $^{[3]}$, Juliana de Souza Almeida Aranha Camargo ${ }^{[1]}$, \\ Eliana Maria Maurício da Rocha ${ }^{[3]}$, Edicarlos André Cavalcante de Araújo[1], \\ Marcelo Zagonel de Oliveira ${ }^{[4]}$, Rafael Vital dos Santos ${ }^{[5]}$ \\ and Luís Marcelo Aranha Camargo ${ }^{[1],[6]}$
}

[1]. Departamento de Medicina, Faculdade São Lucas, Porto Velho, RO. [2]. Departamento de Medicina, Universidade Federal de Rondônia, Porto Velho, RO. [3]. Campus Centro Oeste, Universidade Federal de São João del Rei, Divinópolis, MG. [4]. Departamento de Genética, Universidade Federal do Rio Grande do Sul, Instituto Nacional de Genética Médica Populacional, Porto Alegre, RS. [5]. Laboratório de Biologia Molecular, Instituto de Ciências Biológicas, Universidade Federal de Alagoas, Maceió, AL. [6]. Instituto de Ciências Biomédicas 5, Universidade de São Paulo, Monte Negro, RO.

\begin{abstract}
Introduction: The aim of this work was to identify possible lymphatic filariasis foci in the western Brazilian Amazonian that could be established from the reports of Rachou in the 1950s. The study was conducted in three cities of the western Brazilian Amazon region - Porto Velho and Guajará-Mirim (State of Rondonia) and Humaitá (State of Amazonas). Methods: For human infection evaluation thick blood smear stained with Giemsa was used to analyze samples collected from 10pm to 1am. Polymerase chain reaction (PCR) was used to examine mosquito vectors for the presence of Wuchereria bancrofti DNA. Humans were randomly sampled from night schools students and from inhabitants in neighborhoods lacking sanitation. Mosquitoes were collected from residences only. Results: A total 2,709 night students enrolled in the Program for Education of Young Adults (EJA), and 935 people registered in the residences near the schools were examined, being 641 from Porto Velho, 214 from Guajará-Mirim and 80 from Humaita. No individual examined was positive for the presence of microfilariae in the blood stream. A total of 7,860 female Culex quinquefasciatus specimens examined were negative by PCR. Conclusions: This survey including human and mosquito examinations indicates that the western Amazon region of Brazil is not a focus of Bancroftian filariasis infection or transmission. Therefore, there is no need to be included in the Brazilian lymphatic filariasis control program.
\end{abstract}

Keywords: Lymphatic filariasis. Bancroftian filariasis. Amazon Region. Wuchereria bancrofti. Culex quinquefasciatus.

\section{INTRODUCTION}

Lymphatic filariasis, caused by Wuchereria bancrofti, is considered a neglected disease that affects the lives of people in many endemic regions of Asia, Latin America, and Africa. The parasite is transmitted by Culex quinquefasciatus, especially in socially and economically depressed communities with no sanitation systems or treated water.

Currently, more than 1.3 billion people are at risk of the disease in 72 endemic countries. Approximately $65 \%$ of those people live in southeastern Asia and 30\% in Africa, with the remainder in other tropical areas of the world ${ }^{1-3}$. In the Americas there are active foci in Brazil, Guyana, Haiti and the

\footnotetext{
Address to: Dr. Luís Marcelo Aranha Camargo. ICB5/USP. Rua Francisco Prestes, 2827, Setor II, 76888-000 Monte Negro, RO, Brasil.

Phone: 5569 3530-2349

e-mail: spider@icbusp.org

Received in 15/07/2012

Accepted in 14/02/2013
}

Dominican Republic, with 12.4 million people requiring mass drug administration. Haiti accounts for the highest proportion².

The only focus of lymphatic filariasis known in Brazil is the metropolitan area of Recife (State of Pernambuco) ${ }^{3}$. Cities such as Belém (State of Pará) and Manaus (State of Amazonas), in the Amazon region, and Maceió (State of Alagoas), in Northeast Brazil, have been described as endemic areas in the past. However, these foci have been extinguished and are presently kept under surveillance ${ }^{3,4}$.

In 1953, a hemoscopic survey was performed in Porto Velho, State of Rondonia, Brazil, in which 1,400 individuals were examined ( $12 \%$ of the population) and $6(0.4 \%)$ were positive for $W$. bancrofti microfilariae ${ }^{5}$. However, none of these individuals was autochthonous but were, rather, migrants from areas known to be endemic at the time, such as Belém (PA) and Manaus (AM), who had been living in Porto Velho for a shorter time than the parasite's prepatent period ${ }^{5}$.

In 1953, in State of Rondonia, another hemoscopic survey was performed in Guajará-Mirim. A total of 603 individuals were examined, and only one $(0.2 \%)$ was positive for $W$. bancrofti microfilariae; however, this case was reported as not being autochthonous ${ }^{6}$. Simultaneously, a hemoscopic survey was 
performed in Humaita (AM), but none of the 435 individuals examined was found infected ${ }^{6}$.

Porto Velho has never been an endemic area of lymphatic filariasis, unlike other Amazonian cities such as Manaus and Belem, which were foci of active filariasis transmission.

The existence of many unconfirmed reports of elephantiasis cases in Porto Velho, the lack of further epidemiological surveys after those performed by Rachou et al. ${ }^{5}$ in the 1950 s, and the high density of C. quinquefasciatus prompted the present research, which was conducted to examine the actual occurrence of this endemic disease in that region.

\section{METHODS}

\section{Survey of human infection/Inclusion and exclusion criteria}

Individuals under the age of five years old were excluded, as the hypothesis considered that a short time of exposure to infection would not justify the examination. Individuals who refused to participate in the survey were also excluded. All remaining individuals aged five years and over participated in the survey.

The criteria used to select the places to be evaluated included areas populated earlier in the studied cities, exhibiting urban poor characteristics with respect to their infrastructure, basic sanitation, open-air sewage and houses built on wood pilings, which met the conditions required for vector growth.

\section{Study areas}

Domicile survey in the Municipality of Porto Velho: The peripheral area and older neighborhoods of Porto Velho ( $8^{\circ} 45^{\prime}$ $42.57^{\prime \prime} \mathrm{S}, 63^{\circ} 54^{\prime} 07.06^{\prime}$ 'W) were the target areas of the study alongside the Madeira River, where there are slums and houses built on pilings. The neighborhood and residences of Porto Velho were randomly sampled. The sample size was calculated after mapping and a census of the neighborhoods by taking each dwelling as a sample unit, using an empirical prevalence of $1 \%$, a design effect for cluster surveys of 1.8 and a confidence interval of $95 \%$ calculated by OpenEpi ${ }^{7}$. In this case, the sample size was estimated as a total of 557 randomly selected dwellings and 974 individuals older than five years old. To perform the study, the selected neighborhoods were divided into seven sectors, and $1 / 3$ of the houses in each section were randomized and selected.

Domicile survey in the Municipality of Guajará-Mirim: All dwellings in the old neighborhood of Triangulo in Guajará-Mirim $\left(10^{\circ} 47^{\prime} 27.33^{\prime \prime} \mathrm{S}, 65^{\circ} 19^{\prime} 55.98^{\prime \prime} \mathrm{W}\right)$ were selected because they shared the same poor urban infrastructure characteristics as the areas of Porto Velho. The population of Triângulo was estimated to comprise 506 individuals of all ages, and a total of 214 (31.7\%) blood samples were collected. Individuals more than five years old living in the selected area participated in the survey. The sample was not randomized and was intended to comprise all the inhabitants and houses.

Domicile survey in the Municipality of Humaita, State of Amazonas: All dwellings of the old neighborhood of Santo Antonio in Humaita $\left(7^{\circ} 30^{\prime} 22.20^{\prime \prime} \mathrm{S}, 63^{\circ} 01^{\prime} 37.82^{\prime \prime} \mathrm{W}\right)$ were selected, with 80 houses featuring a similar infrastructure as those in the previously described areas and with a population of 240 inhabitants. The sample was not randomized and was intended to comprise all houses and inhabitants.

Figure 1 shows the areas of research for $W$. bancrofti in the western Amazonian region and the old and present foci of lymphatic filariasis in Brazil (Figure 1).

\section{Survey of night students}

Since evening students include mainly adolescents and young adults, the highest-risk group for bancroftosis ${ }^{8}$, and because of the parasite's nocturnal periodicity in the region, the survey was also performed in public night schools in Porto Velho, Guajara-Mirim, and Humaita. All 23 schools, which have a total of 3,601 students in the target area, were located within the oldest risk areas of the three cities involved in the Program for Education of Young Adults (EJA). These schools provide education to any student, youth and adult older than 18. All the students who wanted to participate were included in the sample.

\section{Blood samples and diagnosis}

The blood samples were collected from $10 \mathrm{pm}$ to $1 \mathrm{am}$ in the dwellings and from 10 to $11 \mathrm{pm}$ in the schools due to the nightly periodicity of the microfilariae in the peripheral blood stream of the human hosts 9 . The thick blood smear (TBS) method was used for the diagnosis according to the following protocol: blood collection was performed by finger prick using a disposable lancet and used for the preparation of TBS equivalent to $0.06-0.08 \mathrm{~mL}$ of blood, which were dried at room temperature. Twelve hours after being dried, the TBSs were dehemoglobinized, fixed with methanol, stained with eosin at $0.05 \%$, and then stained with Giemsa. The slides were examined under an optical microscope with an objective lens with magnifications ranging from 10 to 40X in a blinded manner by two independent examiners.

\section{Survey of mosquito infection}

Vector collection: The Culicidae captures were performed in Porto Velho, Guajará-Mirim and Humaita in the neighborhoods of the humans who participated in this study. All the dwellings were visited and registered except locked dwellings and those whose owners refused to participate in the survey. The number of visited dwellings exceeded the originally sampled dwellings to increase the number of mosquitoes captured. An aspirator was used to collect adult mosquitoes (Castro aspirator). Ingurgitated insects were captured inside the houses from 7 to $10 \mathrm{am}$. The insects were placed inside special fine mesh cages, separated according to the collection location and date, and then taken to the laboratory. The captured C. quinquefasciatus females were selected, placed inside test tubes (five mosquitoes/tube), and frozen at $-20^{\circ} \mathrm{C}$ for further polymerase chain reaction (PCR).

Detection of $W$. bancrofti in mosquitoes by polymerase chain reaction (PCR): Briefly, genomic DNA was isolated from blood-engorged mosquitoes using the method described by Vasuki et al. ${ }^{10}$ with minor modifications. Dried mosquitoes (five per tube) were macerated with $100 \mu \mathrm{L}$ of TE buffer $(10 \mathrm{mM}$ Tris- $\mathrm{HCl}, 0.1 \mathrm{mM}$ EDTA, $\mathrm{pH} 8.0$ ) and incubated at $100^{\circ} \mathrm{C}$ for $10 \mathrm{~min}$. After incubation, the DNA was isolated using a Microcon 


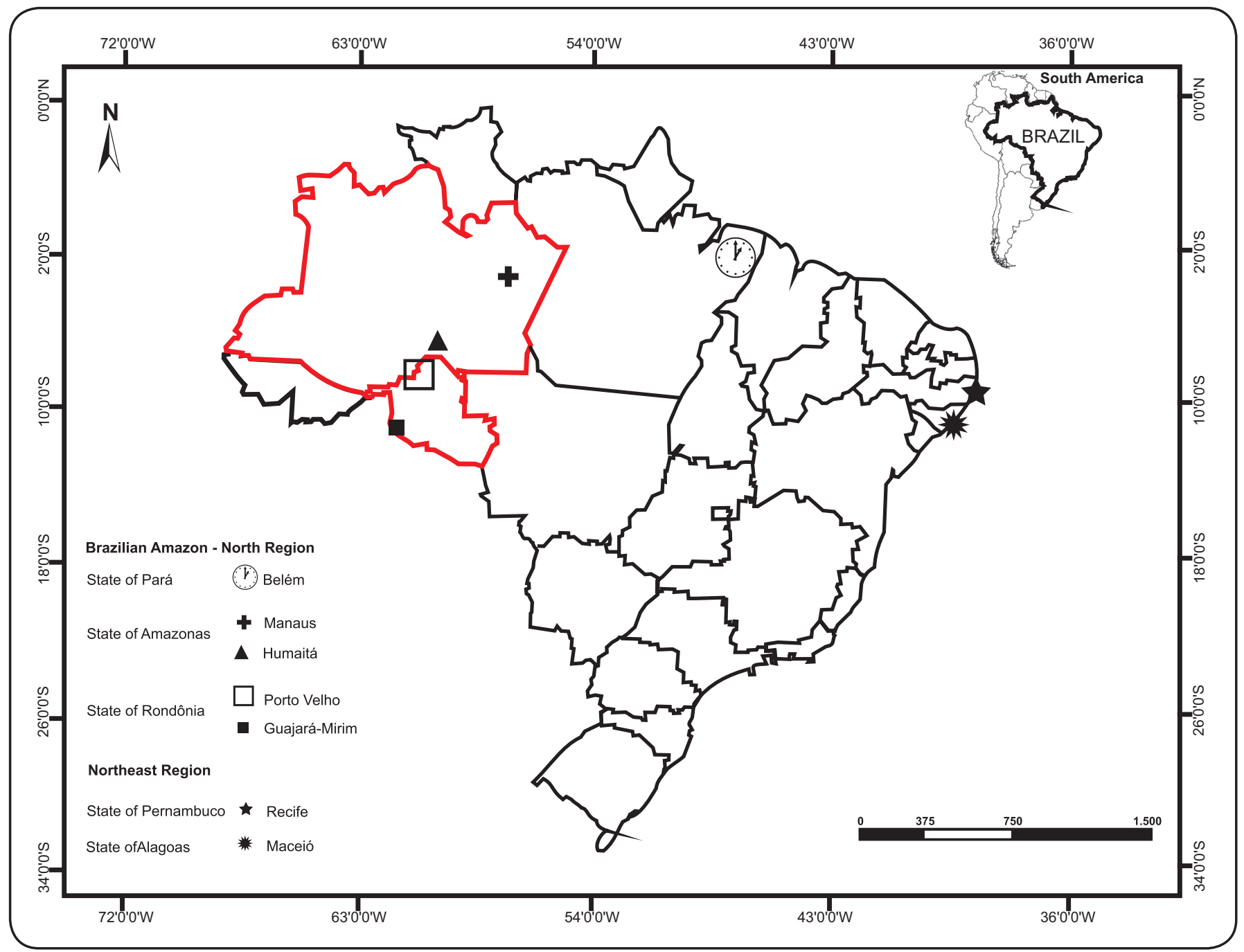

FIGURE 1 - Map showing the survey locations (Porto Velho, Guajará-Mirim and Humaita), the old foci of lymphatic filariasis transmission where the disease has already been eliminated (Belém, Manaus and Maceió), and the only area where lymphatic filariasis transmission is still present (Recife and its metropolitan area).

YM-100 centrifugal filter device (millipore) according to the manufacturer's instructions, a step introduced in the original technique in order to concentrate the extracted DNA. The PCR was conducted using the primer pair NV1 (5'- CGT GAT GGC ATC AAA GTA GCG - '3) and NV2 (5'- CCC TCA CTT ACC ATA AGA CAA - '3) to detect the 188bp target repeat fragment (SspI) of W. bancrofti (SspI; GenBank accession n. L20344) $)^{11}$. Conventional PCR were performed in a volume of $25 \mu \mathrm{L}$ containing $20 \mathrm{pmol}$ of each primer (NV1/NV2), 200 $\mu \mathrm{M}$ deoxyribonucleotide triphosphates (dNTPs), PCR buffer (50 mM KCl, $10 \mathrm{mM}$ Tris- $\mathrm{HCl}, \mathrm{pH} 8.4$ ), $1.5 \mathrm{mM} \mathrm{MgCl}$, ultrapure DNA-free water, $1.5 \mathrm{U} / \mu \mathrm{L}$ Taq DNA polymerase and $4 \mu \mathrm{L}$ of template DNA. All reagents were from Invitrogen ${ }^{\circledR}$. The PCR thermal cycling (PCR Express ThermoHybaid ${ }^{\mathrm{TM}}$ ) conditions were 35 cycles of $92^{\circ} \mathrm{C}$ for $1 \mathrm{~min}, 55^{\circ} \mathrm{C}$ for $1 \mathrm{~min}$, and $72^{\circ} \mathrm{C}$ for $1 \mathrm{~min}$. The PCR amplicons were run on a $1.5 \%$ $(\mathrm{m} / \mathrm{v})$ agarose gel at $90 \mathrm{~V}$ for $1 \mathrm{~h}$, stained with ethidium bromide $(4 \mathrm{mg} / \mathrm{mL})$, and visualized under ultraviolet illumination (Vilber Lourmat ${ }^{\mathrm{TM}}$ TFX-20.M). The gels were photographed using a video documentation system (Vilber Lourmat ${ }^{\mathrm{TM}}$ DP-001 FDC) and then analyzed (photoCaptMW for Windows 10.01 Vilber Lourmat $\left.^{\mathrm{TM}}\right)$.

\section{Ethical considerations}

Every person examined signed a consent form and was well informed before being engaged in the survey, and the participation of the minors was authorized by their parents or guardians. Every person examined was able to sign his/ her name. The project was approved by the Internal Review Board (IRB) of São Lucas College on December 11, 2007, and registered under the number 143/2007 and by the REC of São Paulo University (USP).

\section{RESULTS}

\section{Human Infection}

Domicile surveys in the Cities of Porto Velho, GuajaráMirim and Humaitá: In Porto Velho, 493 houses were visited ( $88.5 \%$ of the total houses selected for inclusion), and 641 
people were surveyed ( $65.8 \%$ of the individuals in the defined area). In Guajará-Mirim, 169 houses were visited (100\% of the houses in the defined area), and 214 dwellers were examined (42.3\% of the total individuals). In Humaitá, all 80 houses of the old neighborhood of the Santo Antonio Community were visited, and 80 individuals were surveyed (33.3\% of the total individuals). In the three surveyed areas, all examined samples were negative for microfilariae (Table 1).

Night students survey: Out of 3,601 students, 2,709 were examined in the three research areas. In Porto Velho, the visits involved 11 schools in the previously defined area and included 1,684 (71.1\%) students. In Guajará-Mirim, all five schools in the previously defined area were visited, and $272(81.2 \%)$ students were examined. In Humaita, all seven night schools in the previously defined area were visited, and $753(83.6 \%)$ students were examined (Table 2). All results were negative for microfilariae in the students blood. This study found no evidence of microfilarial infection in any of the individuals studied in all three areas (Table 2).

Survey of the infection of mosquito vectors: A total of 8,212 female mosquitoes were collected in the three target areas, with 95.8\% (7,860) being C. quinquefasciatus and $4.2 \%$ belonging to other genera, including Aedes, Psorophora and Anopheles. PCR was performed to detect the DNA of $W$. bancrofti in all C. quinquefasciatus females, but none of the mosquitoes was positive (Table 3).

TABLE 1 - Results of thick blood smear examination for Wuchereria bancrofti infection carried out among the population of three cities in the Amazon region of Brazil 2008/2009.

\begin{tabular}{|c|c|c|c|c|c|c|c|}
\hline Municipalities & $\begin{array}{r}\text { Number of houses in } \\
\text { the surveyed area }\end{array}$ & \multicolumn{2}{|c|}{ Visited houses } & $\begin{array}{l}\text { Number of dwellers } \\
\text { in the surveyed area* }\end{array}$ & \multicolumn{2}{|c|}{ Examined dwellers** } & $\begin{array}{c}\text { Result } \\
\text { positive exams }\end{array}$ \\
\hline Porto Velho & 557 & 493 & 88.5 & 974 & 641 & 65.8 & 0 \\
\hline Humaita & 80 & 80 & 100.0 & 240 & 80 & 33.3 & 0 \\
\hline Total & 806 & 742 & 92.0 & 1,720 & 935 & 54.4 & $\mathbf{0}$ \\
\hline
\end{tabular}

*All ages, including children under 5 year old; **People who accepted to participate in the survey over 5 years old.

TABLE 2 - Results of thick blood smear examinations for Wuchereria bancrofti infection carried out among students older than 18 years in schools, in three cities in the Amazon region of Brazil - 2009.

\begin{tabular}{|c|c|c|c|c|c|}
\hline \multirow[b]{2}{*}{ Municipalities } & \multirow{2}{*}{$\begin{array}{l}\text { Number of schools } \\
\text { enrolled in the study }\end{array}$} & \multirow{2}{*}{$\begin{array}{l}\text { Total number } \\
\text { of students }\end{array}$} & \multicolumn{2}{|c|}{ Students examined } & \multirow{2}{*}{$\begin{array}{c}\text { Result } \\
\text { positive exam }\end{array}$} \\
\hline & & & $n$ & $\%$ & \\
\hline Porto Velho & 11 & 2,368 & 1,684 & 71.1 & 0 \\
\hline Guajara-Mirim & 5 & 333 & 272 & 81.7 & 0 \\
\hline Humaita & 7 & 900 & 753 & 83.7 & 0 \\
\hline Total & 23 & 3,601 & 2,709 & 75.2 & $\mathbf{0}$ \\
\hline
\end{tabular}

TABLE 3 - Results of the screening of Culex quinquefasciatus mosquitos for Wuchereria bancrofti DNA examined by polymerase chain reaction (PCR), collected in three cities of Brazilian Amazon region - 2008/2009.

\begin{tabular}{|c|c|c|c|c|c|c|c|c|c|}
\hline \multirow[b]{2}{*}{ Municipality } & \multirow{2}{*}{$\begin{array}{l}\text { Number of } \\
\text { dwellings* }\end{array}$} & \multicolumn{2}{|c|}{ Visited houses } & \multicolumn{2}{|c|}{ Houses - mosquitos collection } & \multirow{2}{*}{$\begin{array}{c}\text { Total of female } \\
\text { mosquitoes }\end{array}$} & \multicolumn{2}{|c|}{ Culex } & \multirow{2}{*}{$\begin{array}{c}\text { Result } \\
\text { positive PCR }\end{array}$} \\
\hline & & n & $\%$ & $\mathbf{n}$ & $\%$ & & n & $\%$ & \\
\hline Porto Velho & 1,525 & 1,262 & 82.7 & 1,080 & 85.6 & 3,650 & 3,512 & 96.1 & 0 \\
\hline Humaita & 324 & 164 & 50.1 & 156 & 84.3 & 2,583 & 2,583 & 99.6 & 0 \\
\hline Total & 2,124 & 1,687 & 79.4 & 1,464 & 86.8 & 8,212 & 7,860 & 95.8 & 0 \\
\hline
\end{tabular}

*Some dwellings are not in the same area of the human survey, but in the neighbohood. In this case, the study area was amplified in order to increase mosquito capture.

\section{DISCUSSION}

Since the 1960s, no survey has been performed to determine whether the vicinities of Porto Velho, Guajará-Mirim and Humaitá were or could be silent areas of lymphatic filariasis transmission. The weather conditions of these areas in Amazonas favor the transmission of $W$. bancrofti. In addition, because of its lack of basic sanitation, the known vector of the parasite was present, and autochthonous occurrences have been diagnosed in the area in the past. The aim of this study was to identify why filariasis did not develop in these areas, as found in the survey described above. 
Using the TBS method, this work studied populations settled alongside the rivers in areas favorable for the development of this parasite as well as night students, whose environment conditions were similar to those reported in studies performed in extinct foci, such as Maceió and Belém ${ }^{3}$, and Recife metropolitan region, the only remaining area of filariasis in Brazil. No occurrence or evidence of the disease was found in the studied cities of Rondônia and Amazonas.

In the present study, the diagnostic method was the TBS, and its main limitation is a reduced sensitivity to the identification of patients affected by mild microfilaremia ${ }^{12}$. However, TBS is a rapid, practical and economic technique, commonly applied in large-scale field studies, and features good sensitivity when the parasitemia is greater than 10 microfilariae $/ \mathrm{mL}$ of blood ${ }^{12}$.

This study, as similar surveys performed in other states, endeavored to provide care to the populations that are undoubtedly subjected to higher social and environmental risk factors, that is, extremely poor areas with no basic sanitation systems and that are close to areas of higher vector proliferation. Notably, the investigated municipalities are relatively new, whereas the surveys were performed in contiguous, older areas of these cities. Poor basic sanitation conditions in habitational conglomerates are determining factors that could foster and maintain filariasis transmission. Thus, the populations exposed to higher social and environmental transmission risks were incorporated, and the likelihood of false-negative results for filariasis infection was reduced. In addition to the risk population, the present study included also participants of the Young Adult Students' program of the local State government involving 18 to 35 year old individuals enrolled in basic and mid-level schools. This categorization was chosen for operational reasons according to the studies performed previously in other areas of the country ${ }^{8,13}$. As suggested by Rocha et al. ${ }^{14}$, the prevalence of bancroftosis may occur in young age brackets, which were emphasized in this survey. Furthermore, the surveyed schools were located near those places with a higher probability of the presence of the disease, which are the oldest settlements of the cities with poor urban infrastructure.

The assessment of filariasis transmission was performed by monitoring the infection in the insect vectors by PCR. The PCR has proven to be a powerful tool to evaluate the contamination intensity of the mosquitoes in endemic areas and, because of these advantages, has replaced the conventional dissection methods for the diagnosis of $W$. bancrofti in mosquitoes ${ }^{15}$. This method, in addition to being more sensitive than dissection, enables a large number of samples to be processed in a short period.

Other factors that may have contributed to the nonproliferation of the disease may be associated with the environment, the vector itself, and the cases diagnosed and treated in the 1960s.

Regarding the environment, filariasis is known to occur in tropical and subtropical hot and humid areas. Chandra et al. ${ }^{16}$ found that the density of Culex mosquitoes decrease during rainy periods, although periods of higher temperatures and humidity favor $W$. bancrofti transmission, shortening developmental period from $L_{1}$ to $L_{3}$ (infective larva) stages of the parasite in the vector.
The studied areas of Porto Velho, Guajará-Mirim and Humaitá exhibit the characteristics that facilitate rapid development of the parasite into its infectious larval form. However, during periods of increased heat and humidity, the number of vectors decreases, although there is no synchrony between the infecting larvae and the number of vectors, and the transmission risk decreases. One of the factors that may have contributed to the nonproliferation of the disease is the lack of synchronization between the number of vectors and the environmental conditions for the development of the agent that causes the disease $\mathrm{e}^{17}$.

Several vector types are involved in filariasis transmission, including mosquitoes of the genera Culex, Anopheles, Aedes and Mansonia $^{18}$. In Brazil, the only known vectors are the mosquitoes of the genus Culex, which are prevalent in the studied areas.

Studies with different filariae worms show that the vector efficiency depends on the susceptibility to pathogen infection and the microfilaria density ${ }^{19-21}$. Vectorial competence can be affected by the densities of microfilariae ingested during blood meal, and not all the blood fed mosquitoes became infected. Furthermore, when the insect is exposed to a high concentration of parasites an increased vectorial mortality rate can occur.

The non occurrence of the disease may also be associated with the blood feeding in vectors of low vectorial competence. Not all larvae ingested by the mosquitoes will survive inside the gastrointestinal tract and some of the larvae are expelled by the vector itself, whereas others are injured by the oropharyngeal tract during the repast ${ }^{22}$. As a result, the transmission is reduced ${ }^{22}$.

Those intrinsic and extrinsic factors and the complex interactions between filarial parasites and mosquitoes, that influence vectorial competence, could be in part responsible for geographic distribution of filariasis.

Accordingly, the discussion also involves findings from the studies performed by Hairston and De Meillon ${ }^{23}$, which clearly showed that immature $W$. bancrofti larvae do not survive inside their hosts, thereby largely decreasing the load of contaminative filariae (L3) and increasing the number of bites required for infected mosquitoes to cause a parasitic infection. An estimated 15,500 infecting bites are required to cause microfilaremia ${ }^{23}$. Snow and Michael ${ }^{24}$ in 2002 and Chandra ${ }^{17}$ in 2008 also showed that the filariae present in the vector may increase the likeliness of dissemination but may also be fatal to the vector when their presence is too high by increasing the lethality, which contributes to the reduction in transmission.

Regarding the number of bites by mosquitoes infected with larvae in this survey, no individual was found to have been infected with $W$. bancrofti microfilariae by the TBS method, and no infected mosquito was found by PCR in the areas surveyed, proving the lack of foci formation in the studied areas, such as in the allochthonous cases of $W$. bancrofti reported in the past. In the studied areas, no focus formation was detected, even with the presence of the parasite vectors and appropriate environmental conditions. The factors that influence the probability of the vector being infected and transmitting the infection include 
the microfilarial infection of the vertebrate hosts. The mosquito infection rate is proportional to the microfilariae density in the peripheral blood stream of the patients. Brito et al. ${ }^{25}$ found that the infection rate of mosquitoes fed with the blood of individuals with mild $W$. bancrofti microfilarial infections (1-10 microfilariae/mL) was $0.07 \%$, whereas the efficiency of the vector was nearly $17 \%$. That is, for every six microfilariae ingested, only one reaches the infecting larva stage.

Several studies have demonstrated that the persistence of this endemic disease depends on the occurrence of high natural infection rates of the mosquitoes. Nevertheless, there has been no consensus among researchers that can forecast the occurrence of a new case of patent microfilarial infection in humans ${ }^{26}$. However, below a certain critical number of infecting bites, lymphatic filariasis has not been confirmed to be an endemic disease, which may be the case in this area. In places where the microfilariae density is maintained below five microfilariae $/ 60 \mathrm{~mL}$ blood, there is considered to be no transmission risk ${ }^{27}$.

In a recent study performed in Maceió it was showed that the filarial load in a patient is one of the determining factors for maintaining transmission foci ${ }^{28}$. Such a load may have been one of the factors that determined the disease dissemination in the studied areas. In Maceió, Leite et al. ${ }^{28}$ found that an individual suffering from $W$. bancrofti microfilarial infection who came from an endemic area and had been living for more than 10 years in a nonendemic area, was not capable of inducing the formation of a new bancroftosis focus, even though the new area exhibited the appropriate environmental conditions. One of the possibilities considered by the researchers was the mild microfilarial infection of the infected individual (4 microfilariae/mL of blood) ${ }^{28}$.

However, with the growing migration in the country, there is a risk that the disease might be introduced in areas free of the infection ${ }^{3}$. In Sri Lanka infected migrants have engendered lymphatic filariasis in areas where the disease was previously unknown $^{29}$. This occurred also in metropolitan Recife, where cases of the parasitosis appeared in previously unaffected $\operatorname{areas}^{30,31}$.

The magnitude of the potential risk for the establishment of sustainable foci of lymphatic filariasis depends mainly on the number of $W$. bancrofti carriers, the microfilarial density in these individuals, the existence of potential vectors, and environmental conditions that favor transmission ${ }^{32-34}$.

Finally, the few people suffering from $W$. bancrofti microfilarial infections found in the Cities of Porto Velho and Guarajá-Mirim in the 1950s had allochthonous, mild microfilarial infections (out of the seven people infected with parasites, five had fewer than five microfilariae per slide examined $)^{5,35}$. It appears that the small number of people infected with the parasites and the mild nature of the microfilarial infection reported in the 1950s in Porto Velho and Guarajá-Mirim were not sufficient to establish and maintain the lymphatic filariasis in the examined areas, which were considered harmless and may or may not be associated with environmental and other factors related to the vectors.

\section{ACKNOWLEDGMENTS}

The authors are especially grateful to the following for their support of this study: Dilene Morais B. da Silva, Célia Gonçalves Pereira, Beatriz Santos, and Suzane Neves Velasques. We acknowledge and give thanks to the students of São Lucas College, the population of the surveyed cities and the directors of the Program for Education of Young Adults (EJA).

\section{CONFLICT OF INTEREST}

The authors declare that there is no conflict of interest.

\section{FINANCIAL SUPPORT}

Fundação de Amparo à Pesquisa do Estado de São Paulo (FAPESP) Proj no. 2007/00848-9.

\section{REFERENCES}

1. World Health Organization. Global Programme to Eliminate Lymphatic Filariasis. Progress report on mass drug administrations in 2007. Wkly Epidemiol Rec 2008, 83:333-348.

2. World Health Organization. Global Programme to Eliminate Lymphatic Filariasis. Progress report on mass drug administration in 2010. Wkly Epidemiol Rec 2011; 86:377-388.

3. Fontes G, Leite AB, Lima ARV, Freitas H, Ehrenberg JP, Rocha EMM. Lymphatic filariasis in Brazil: Epidemiological situation and outlook for elimination. Parasit Vectors 2012; 5:272.

4. Fontes G, Braun RF, Fraiha-Neto H, Vieira JBF, Padilha SS, Rocha RC, et al. Filariose linfática em Belém, Estado do Pará, Norte do Brasil e a perspectiva de eliminação. Rev Soc Bras Med Trop 2005; 38:131-136.

5. Rachou RG, Lacerda NB, Costa A. Inquérito hemoscópico para pesquisa de microfilárias em Porto Velho, capital do território do Guaporé. Rev Bras Malariol D Trop 1954; 6:501-503.

6. Rachou RG. Distribuição geográfica das Filarioses humanas no Brasil. Rev Bras Malariol D Trop 1957; 9:79-100.

7. Dean AG, Sullivan KM, Soe MM. OpenEpi: Open Source Epidemiologic Statistics for Public Health, Version 2.3.1. [Updated 2011 June 23]. [Accessed on 2012 July 7]. Available from: www.OpenEpi.com/.

8. Fontes G, Rocha EMM, Brito AC, Antunes CMF. Lymphatic Filariasis in Brazilian Urban Area (Maceió, Alagoas). Mem Inst Oswaldo Cruz 1998; 93:705-710.

9. Fontes G, Rocha EMM, Brito AC, Fireman AT, Antunes CMF. The microfilarial periodicity of Wuchereria bancrofti in northeastern Brazil. Ann Trop Med Parasitol 2000; 94:373-379.

10. Vasuki V, Hoti SL, Sadanandane C, Jambulingam P. A simple and rapid DNA extraction method for the detection of Wuchereria bancrofti infection in the vector mosquito Culex quinquefasciatus by Ssp I PCR assay. Acta Trop 2003; 86:109-114.

11. Zhong M, McCarthy J, Bierwert L, Lizotte-Waniewski M, Chanteau S, Nutman $\mathrm{TB}$,et al. A polymerase chain reaction assay for detection of theparasite Wuchereria bancrofti in human blood samples. Am J Trop Med Hyg 1996; 54:357-363.

12. Fontes G, Rocha EMM. Wuchereria bancrofti - Filariose Linfática. In: Neves DP, Melo AL, Linardi PM, Vitor RWA, editors. Parasitologia Humana. 12th ${ }^{\mathrm{a}}$ ed. São Paulo: Atheneu; 2011. p. 323-333. 
13. Dreyer G, Medeiros Z, Béliz F, Vergetti G, Vergetti A, Café T, et al. Autochthonous Wuchereria bancrofti microfilaremia in the city of MaceióAlagoas-Brazil. Mem Inst Oswaldo Cruz 1991; 86:495-496.

14. Rocha EMM, Fontes G, Brito AC, Silva TRC, Medeiros Z, Antunes CMF. Filariose bancroftiana em áreas urbanas do Estado de Alagoas, nordeste do Brasil: estudo em população geral. Rev Soc Bras Med Trop 2000; 33:545-551.

15. Bockarie MJ, Fischer P, Williams SA, Zimmerman PA, Griffin L, Alpers MP, et al. Application of a polymerase chain reaction-ELISA to detect Wuchereria bancrofti in pools of wildcaught Anopheles punctulatus in filariasis control area in Papua New Guinea. Am J Trop Med Hyg 2000; 62:363-367.

16. Chandra G, Chatterjee SN, Banerjee BD, Majumdar G. Effect of seasonal variations on the development of Wuchereria larvae in Culex quinquefasciatus. Basic Appl Biomed 1997; 5:21.

17. Chandra G. Nature limits filarial transmission. Parasit Vectors 2008; 1:13.

18. Ramachandran CP. A guide to methods and techniques in filariasis investigations. Filariasis Research Officer. Inst Med Res Kuala Lumpur Bull 1970; 15:1-39.

19. Brito AC, Rocha DAM, Vila-Nova DA, Costa LG, Almeida WAP, Viana LS, et al. Prevalência da filariose canina causada por Dirofilaria immitis e Dipetalonema reconditum em Maceió, Alagoas, Brasil. Cad Saude Publica 2001; 17:1497-1504.

20. Christensen BM, Sutherland DR, Gleason LN. Defense reactions of mosquitoes to filarial worms: comparative studies on the response of three different mosquitoes to inoculated Brugia pahangi and Dirofilaria immitis microfilariae. J Invertebr Pathol 1984; 44:267-274.

21. Carvalho GA, Alves LC, Maia RT, Andrade CFS, Ramos RAN, Faustino MAG. Vector competence of Culex quinquefasciatus Say, 1823 exposed to different densities of microfilariae of Dirofilaria immitis (Leidy, 1856). Rev Bras Entomol 2008; 52:658-662.

22. Serrão ML, Labarthe N, Lourenço de Oliveira R. Vectorial competence of Aedes aegypti (Linnaeus 1762) Rio de Janeiro strain, to Dirofilaria immitis (Leidy, 1856). Mem Inst Oswaldo Cruz 2001; 96:593-598.

23. Hairston NG, Meillon MB. On the inefficiency of transmission of Wuchereria bancrofti from mosquito to human host. Bull World Health Org 1968; 38:935-941.

24. Snow LC, Michael E. Transmission dynamics of lymphatic filariasis: densitydependence in the uptake of Wuchereria bancrofti microfilariae by vector mosquitoes. Med Vet Entomol 2002; 16:e409-423.
25. Brito AC, Fontes G, Williams P, Rocha EMM. Bancroftian filariasis in Maceió, State of Alagoas, Brazil: observations on Culex quinquefasciatus after blood feeding on individuals with different densities of microfilariae in the peripheral blood stream. Am J Trop Med Hyg 1998; 58:489-494.

26. Witt C, Ottesen EA. Lymphatic filariasis: an infection of childhood. Trop Med Int Health 2001; 6:582-606.

27. Das PK, Vanamail P. Probability risk transmission matrix as a decision tool for assessing methods of transmission interruption of Wuchereria bancrofti infection. Epidemiol Infect 2007; 20:1-5.

28. Leite AB, Lima ARV, Leite RB, Santos RV, Gonçalves JEL, Rocha EMM, et al. Assessment of family and neighbors of an individual infected with Wuchereria bancrofti from a non-endemic area in the city of Maceió, Brazil. Braz J Infect Dis 2010; $14: 125-128$.

29. Organización Mundial de la Salud: Filariasis linfática: Cuarto informe del Comité de Expertos de la OMS en Filariasis. Serie de Informes Técnicos 702. Ginebra: Organización Mundial de la Salud; 1984. p.121.

30. Medeiros Z, Gomes J, Béliz F, Coutinho A, Dreyer P, Dreyer G. Screening of army soldiers for Wuchereria bancrofti infection in metropolitan Recife region Brazil: implications for epidemiologic surveillance. Trop Med Int Health 1999; 4:499-505.

31. Medeiros Z, Alves A, Brito JA, Borba L, Santos Z, Costa JP, et al. The present situation regarding lymphatic filariasis in Cabo de Santo Agostinho Pernambuco Northeast Brazil. Rev Inst Med Trop Sao Paulo 2006; 48:263-267.

32. Sutherst, RW. Global change and human vulnerability to vector-borne diseases. Clin Microbiol Rev 2004; 17:136-173.

33. Bonfim C, Alves A, Costa TR, Alencar F, Pedroza D, Portugal JL, et al. Spatial analysis and privation index to identify urban areas with a high risk of lymphatic filariasis. Trop Med Int Health 2011; 16:748-755.

34. Simonsen PE, Mwakitalu ME. Urban lymphatic filariasis. Parasitol Res 2013: 112:35-44.

35. Rachou RG. Conceito e programa de profilaxia da filariose bancroftiana no Brasil. Rev Bras Malariol D Trop 1960; 12:11-40. 
ANEXO A - Informativo sobre filariose em Porto Velho

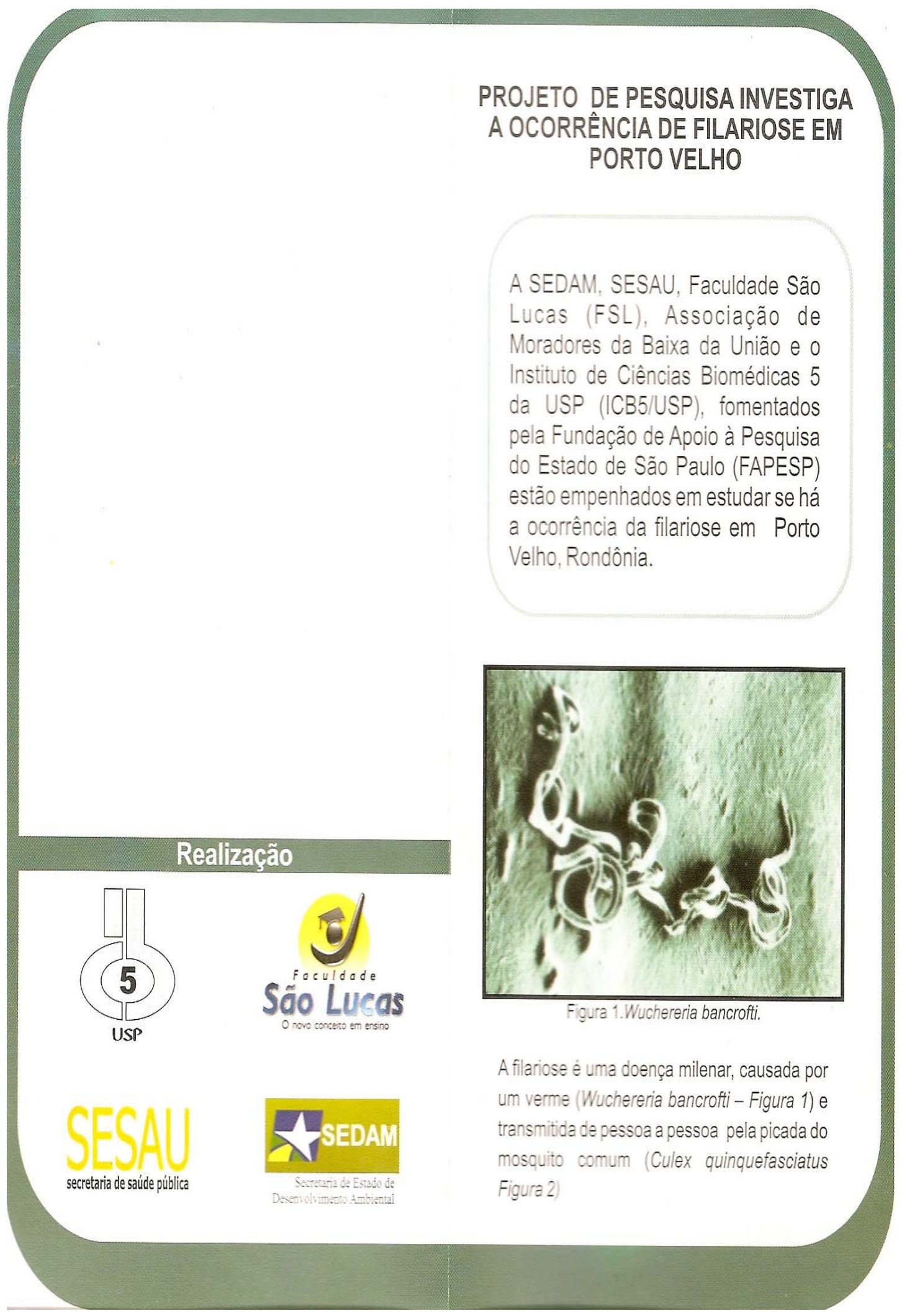




\section{ANEXO B - Resolução 50.29 da WHA}

\section{RESOLUTIONS AND DECISIONS 1}

WHA50.29 Elimination of lymphatic filariasis as a public health problem

The Fiftieth World Health Assembly,

Deeply concerned at the spread and increased distribution of lymphatic filariasis throughout the world in both urban and rural areas, and at the evidence that it affects all ages and both sexes; Appreciating with grave concern the human suffering, social stigma and costs to society associated with lymphatic filariasis morbidity;

Recognizing that there is a general lack of awareness concerning this disease and its impact on health status, and that there are insufficient data on its prevalence and distribution;

Welcoming the recent studies which have defined new, simplified, highly effective strategies; Acknowledging that an international task force on disease eradication has recently identified lymphatic filariasis as one of only six "potentially eradicable” infectious diseases,

1. URGES Member States:

(1) to take advantage of recent advances in the understanding of lymphatic filariasis and the new opportunities for its elimination by developing national plans leading to its elimination, as well as for the monitoring and evaluation of programme activities;

(2) to strengthen local programmes and their integration with the control of other diseases, particularly at the community level, in order to implement simple, affordable, acceptable and sustainable activities based on community-wide treatment strategies, but supplemented where feasible by vector control and improved sanitation;

(3) to strengthen capabilities for training, research, laboratory diagnostic, disease management and data management in order to improve clinical, epidemiological and operational activities directed toward eliminating lymphatic filariasis as a public health

RESOLUTIONS AND DECISIONS 2

problem;

(4) to mobilize support of all relevant sectors, affected communities and nongovernmental organizations for the elimination of the disease;

2. INVITES other specialized agencies of the United Nations system, bilateral development agencies, nongovernmental organizations and other groups concerned, to increase cooperation in the elimination of lymphatic filariasis through support of national and international programmes relevant to the prevention and elimination of lymphatic filariasis;

3. REQUESTS the Director-General: 
(1) to bring to the attention of the other specialized agencies and organizations of the United Nations system, bilateral development agencies, nongovernmental organizations and other groups concerned the need for closer collaboration in the elimination of lymphatic filariasis as a public health problem;

(2) to mobilize support for global and national elimination activities;

(3) to keep the Executive Board and Health Assembly informed as necessary of progress in the implementation of this resolution.

Hbk Res., Vol. III (3rd ed.), 1.16.3.3; 7.1.3 (Ninth plenary meeting, 13 May 1997 Committee A, third report) 